\title{
An Azophosphine Synthetic Equivalent of Mesitylphosphaazide and Its 1,3-Dipolar
}

\section{Cycloaddition Reactions}

Martin-Louis Y. Riu ${ }^{1}$, Wesley J. Transue ${ }^{1}$, Jan M. Rall ${ }^{1}$, and Christopher C. Cummins $^{1 *}$

${ }^{1}$ Department of Chemistry, Massachusetts Institute of Technology, Cambridge, MA 02139, USA

E-mail: ccummins@mit.edu

\section{Table of Contents}

S.1 Synthetic Details

S.1.1 General Information . . . . . . . . . . . . . . . . . . . . S.3

S.1.2 Synthesis of $\mathrm{MesN}_{2} \mathrm{PA}(\mathbf{1}) \ldots \ldots \ldots \ldots \ldots \ldots \ldots \ldots$

S.1.2.1 Quantification of Conversion using an Internal Standard . . . . . S.8

S.1.2.2 UV-Visible Spectroscopic Analysis of $1 \ldots \ldots \ldots \ldots$

S.1.2.3 Air Stability of 1 in Solution _. . . . . . . . . . . . . S.9

S.1.2.4 Thermal Decomposition of $\mathbf{1}$ in Solution . . . . . . . . . . . . . S.11

S.1.2.5 Kinetic Study on 1 Thermolysis . . . . . . . . . . . . . . S.13

S.1.3 Synthesis of 2 from 1 and Cyclooctyne . . . . . . . . . . S.15

S.1.4 Synthesis of $[\mathbf{3}]\left[\mathrm{Na}(12 \text {-crown-4) })_{2}\right]$ from $\left[\mathrm{Na}(\text { dioxane })_{2.5}\right][\mathrm{OCP}]$ and $\mathbf{1} \ldots$. . S.18 
S.1.5 Synthesis of 4 from 1 and 1-Adamantylphosphaethyne . . . . . . . . S.23

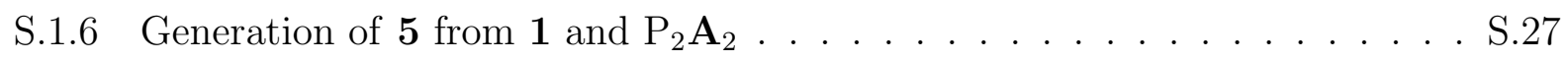

S.2 X-Ray Diffraction Studies $\quad$ S.30

$\begin{array}{llr}\text { S.3 Computational Studies } & \text { S.38 }\end{array}$

S.3.1 Molecular Orbital Analysis of 1 . . . . . . . . . . . . . S.38

S.3.1.1 Coordinates $(\mathrm{xyz})$ of $1 \ldots \ldots \ldots$. . . . . . . . . . . . . . . . . .

S.3.2 Mechanism for 1 Fragmentation . . . . . . . . . . . . . . S.41

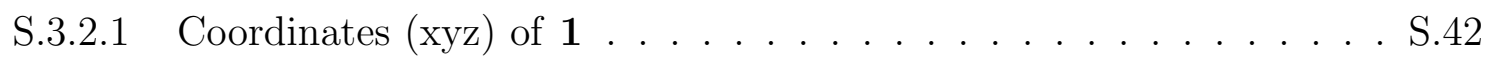

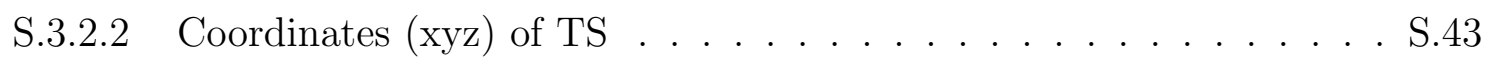

S.3.2.3 Coordinates (xyz) of Anthracene . . . . . . . . . . . S.45

S.3.2.4 Coordinates (xyz) of $\mathrm{MesN}_{2} \mathrm{P} \ldots \ldots \ldots$. . . . . . . . . . . . . . .

S.3.3 Calculated Lowest Energy Pathway for the Reaction of $\mathbf{1}$ and Cyclooctyne to Give $2 \ldots \ldots \ldots \ldots$. . . . . . . . . . . . . . . . . . . . . . . . . .

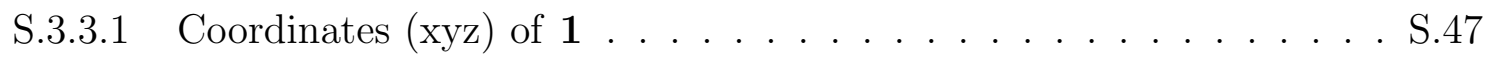

S.3.3.2 Coordinates (xyz) of Cyclooctyne . . . . . . . . . . . S.49

S.3.3.3 Coordinates (xyz) of TS1 . . . . . . . . . . . . . S.50

S.3.3.4 Coordinates $(\mathrm{xyz})$ of $\mathrm{I} 1 \ldots \ldots \ldots \ldots$. . . . . . . . . . . . . . . . . .

S.3.3.5 Coordinates (xyz) of TS2 . . . . . . . . . . . . . S.55

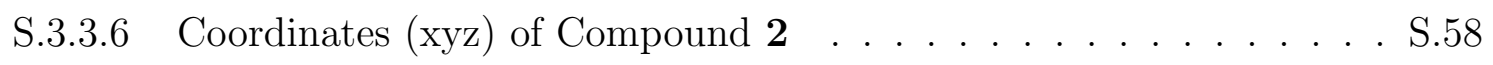

S.3.3.7 Coordinates (xyz) of Anthracene . . . . . . . . . . . S.59

S.3.4 Natural Bond Orbital (NBO) Analysis of Unsubstituted 3 . . . . . . . . S.61

S.3.4.1 Coordinates (xyz) of Parent Molecule . . . . . . . . . . S.62

$\begin{array}{ll}\text { References } & \text { S.62 }\end{array}$ 


\section{S.1 Synthetic Details}

\section{S.1.1 General Information}

Except as otherwise noted, all manipulations were performed in a Vacuum Atmospheres model MO-40M glovebox under an inert atmosphere of purified $\mathrm{N}_{2}$. All solvents were obtained anhydrous and oxygen-free by bubble degassing (Ar), purified by passage through columns of alumina using a solvent purification system (Pure Process Technology, Nashua, $\mathrm{NH}),{ }^{1}$ and stored over $4.0 \AA$ molecular sieves. ${ }^{2}$ Deuterated solvents were purchased from Cambridge Isotope Labs, then degassed and stored over $4 \AA$ molecular sieves for at least $48 \mathrm{~h}$ prior to use. Diatomaceous earth (EM Science), $4 \AA$ molecular sieves, and charcoal were dried by heating above $200{ }^{\circ} \mathrm{C}$ under dynamic vacuum for at least $48 \mathrm{~h}$ prior to use. All glassware was dried in an oven for at least two hours at temperatures greater than $150{ }^{\circ} \mathrm{C}$.

$\left[\mathrm{Ph}_{3} \mathrm{BPA}\right]\left[\mathrm{Na}\left(\mathrm{OEt}_{2}\right)_{2}\right]\left(\mathbf{A}=\right.$ anthracene, $\left.\mathrm{C}_{14} \mathrm{H}_{10}\right),{ }^{3} \mathrm{P}_{2} \mathbf{A}_{2},{ }^{4}\left[\mathrm{MesN}_{2}\right] \mathrm{OTf},{ }^{5}$ cyclooctyne, ${ }^{6}$ and $\left.[\mathrm{Na} \text { (dioxane })_{2.5}\right][\mathrm{OCP}]^{7}$ were prepared according to literature procedures. Pyridine (Sigma-Aldrich), 12-crown-4 (Sigma-Aldrich), and $N$-sulfinylaniline (Sigma-Aldrich) were degassed three times by the freeze-pump-thaw method and stored over $4 \AA$ molecular sieves for $48 \mathrm{~h}$ prior to use. 1-Adamantylphosphaethyne (Fluka), acenaphthene (Sigma-Aldrich), 1,4-bis(trimethylsilyl)benzene (Sigma-Aldrich) were used as received.

NMR spectra were obtained on a Jeol ECZ-500 instrument equipped with an Oxford Instruments superconducting magnet, on a Bruker Avance 400 instrument equipped with a Magnex Scientific or with a SpectroSpin superconducting magnet, or on a Bruker Avance 500 instrument equipped with a Magnex Scientific or with a SpectroSpin superconducting

magnet. ${ }^{1} \mathrm{H}$ and ${ }^{13} \mathrm{C}$ NMR spectra were referenced internally to residual solvent signals. ${ }^{8}$ ${ }^{31} \mathrm{P}$ NMR spectra were externally referenced to $85 \% \mathrm{H}_{3} \mathrm{PO}_{4}(0 \mathrm{ppm})$.

High resolution mass spectral (HRMS) data were collected using a Jeol AccuTOF 4G LCPlus mass spectrometer equipped with an Ion-Sense DART source. Data were calibrated to a sample of PEG-600 and were collected in positive-ion mode or negative-ion mode. Samples 
were prepared in THF (ca. $10 \mu \mathrm{M}$ concentration) and were briefly exposed to air $(<5 \mathrm{~s})$ before being placed in front of the DART source. UV-visible spectra were obtained on an Agilent Cary 60 spectrometer.

\section{S.1.2 Synthesis of $\mathrm{MesN}_{2} \mathrm{PA}(1)$}

Aluminum foil was used to limit exposure to ambient light during this experiment. A $100 \mathrm{~mL}$ round bottom flask charged with a solution of $\left[\mathrm{Ph}_{3} \mathrm{BPA}\right]\left[\mathrm{Na}\left(\mathrm{OEt}_{2}\right)_{2}\right](1.00 \mathrm{~g}, 1.61 \mathrm{mmol}$, 1.00 equiv) in THF (15 mL) was frozen in the liquid nitrogen cooled coldwell of the glovebox. Separately, a slurry of $\left[\mathrm{MesN}_{2}\right] \mathrm{OTf}(0.475 \mathrm{~g}, 1.61 \mathrm{mmol}, 1.00$ equiv) in THF (15 $\mathrm{mL}$ ) was prepared and frozen in the coldwell of the glovebox. Upon thawing, the slurry of $\left[\mathrm{MesN}_{2}\right] \mathrm{OTf}$ was added rapidly to the thawing solution of $\left[\mathrm{Ph}_{3} \mathrm{BPA}\right]\left[\mathrm{Na}\left(\mathrm{OEt}_{2}\right)_{2}\right]$. The solution became deep red and homogeneous as it warmed with rapid stirring. After 20 min, all volatile materials were removed in vacuo, resulting in a deep red residue. To this residue was added pentane $(50 \mathrm{~mL})$ and, with rapid stirring, pyridine (0.982 g, $12.4 \mathrm{mmol}, 7.71$ equiv) was added to the solution, causing precipitation of the triphenylborane adduct of pyridine as a colorless solid. ${ }^{9}$ The heterogeneous mixture was filtered through a coarse sintered frit $(15 \mathrm{~mL})$ containing a one-inch plug of diatomaceous earth and the plug was washed with pentane $(50 \mathrm{~mL})$. All volatile materials were removed in vacuo from the combined filtrates, providing purple solids. These solids were taken up in $\mathrm{Et}_{2} \mathrm{O}$ and filtered through a $15 \mathrm{~mL}$ coarse sintered frit containing a one-inch plug of charcoal. The charcoal plug was washed with $\mathrm{Et}_{2} \mathrm{O}(30 \mathrm{~mL})$. All volatile materials were removed in vacuo from the combined filtrates, yielding purple solids. Crystallization from minimal pentane at $-35{ }^{\circ} \mathrm{C}$ afforded purple crystals of $\mathbf{1}(0.080 \mathrm{~g}, 0.23 \mathrm{mmol}, 14 \%)$. Compound $\mathbf{1}$ (ca. $1 \mathrm{mg})$ was loaded into a flame-sealed glass capillary to measure its melting point; however, the sample violently decomposed when heated to $90{ }^{\circ} \mathrm{C}$. The capillary containing the decomposed black material was brought into the glovebox where it was crushed in a vial and its contents extracted into benzene- $d_{6}$. Anthracene and traces of 1 were observed by ${ }^{1} \mathrm{H}$ NMR spectroscopy. DART 
HRMS(Q-TOF) m/z: $[\mathrm{M}+\mathrm{H}]^{+}$Calcd for $\mathrm{C}_{23} \mathrm{H}_{22} \mathrm{~N}_{2} \mathrm{P}$ 357.1576; Found 357.1521 (Fig. S.6). ${ }^{1} \mathrm{H}$ NMR (500 MHz, benzene- $d_{6}, 25{ }^{\circ}$ C, Fig. S.2) $\delta 7.19(\mathrm{dd}, J=3.5,0.9 \mathrm{~Hz}, 2 \mathrm{H}) 6.99$ (ddd, $J=12.2,5.2,3.2 \mathrm{~Hz}, 4 \mathrm{H}), 6.64(\mathrm{~s}, 2 \mathrm{H}) 6.62(\mathrm{dd}, J=5.3,3.2 \mathrm{~Hz}, 2 \mathrm{H}), 4.53\left(\mathrm{~d},{ }^{2} J_{\mathrm{PH}}=\right.$ $12.4 \mathrm{~Hz}, 2 \mathrm{H}), 2.16(\mathrm{~s}, 6 \mathrm{H}), 2.00(\mathrm{~s}, 3 \mathrm{H}) \mathrm{ppm} .{ }^{13} \mathrm{C}\left\{{ }^{1} \mathrm{H}\right\}$ NMR $\left(101 \mathrm{MHz}\right.$, benzene- $d_{6}, 25{ }^{\circ} \mathrm{C}$, Fig. S.3) $\delta 151.86(\mathrm{~d}, J=19.3 \mathrm{~Hz}), 147.60(\mathrm{~d}, J=2.2 \mathrm{~Hz}), 142.56(\mathrm{~d}, J=19.6 \mathrm{~Hz}), 139.16$, $131.51,130.39,127.29,125.12,124.19(\mathrm{~d}, J=3.0 \mathrm{~Hz}), 123.48,54.69\left(\mathrm{~d},{ }^{1} J_{\mathrm{PH}}=17.9 \mathrm{~Hz}\right)$, 21.00, 19.20 ppm. ${ }^{31} \mathrm{P}\left\{{ }^{1} \mathrm{H}\right\}$ NMR (203 MHz, benzene- $d_{6}, 25{ }^{\circ} \mathrm{C}$, Fig. S.4) $\delta 207.8\left(\mathrm{t},{ }^{2} J_{\mathrm{PH}}=\right.$ $12.0 \mathrm{~Hz}) \mathrm{ppm}$.

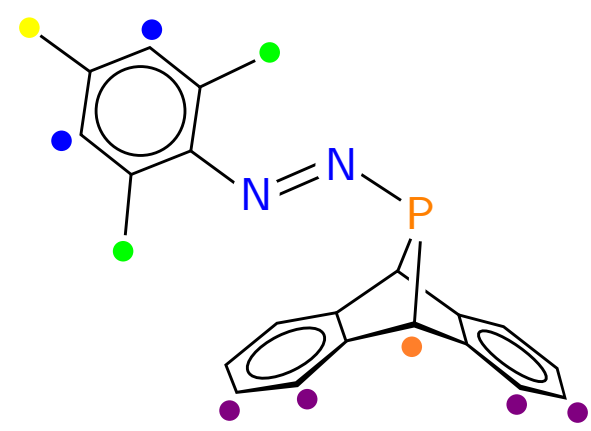

Figure S.1: Labeling scheme for $\mathbf{1}$.

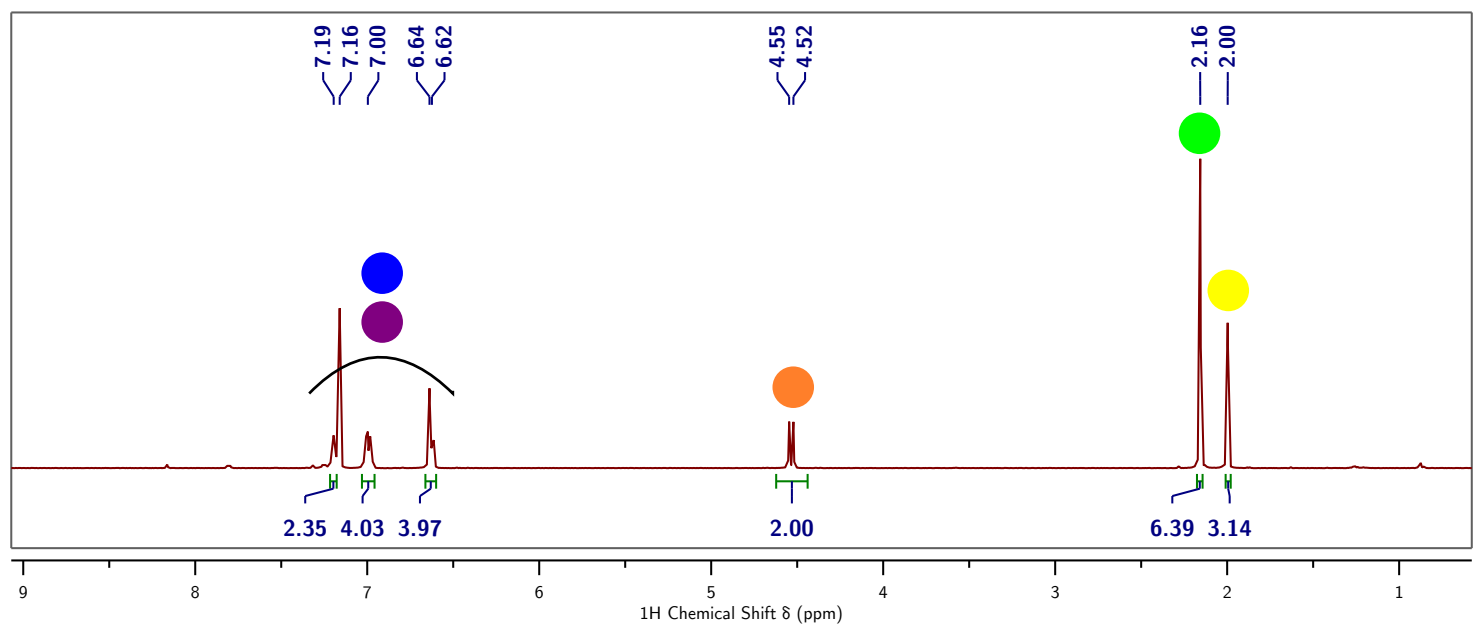

Figure S.2: ${ }^{1} \mathrm{H}$ NMR $\left(500 \mathrm{MHz}\right.$, benzene- $\left.d_{6}, 25{ }^{\circ} \mathrm{C}\right)$ spectrum of 1 . 


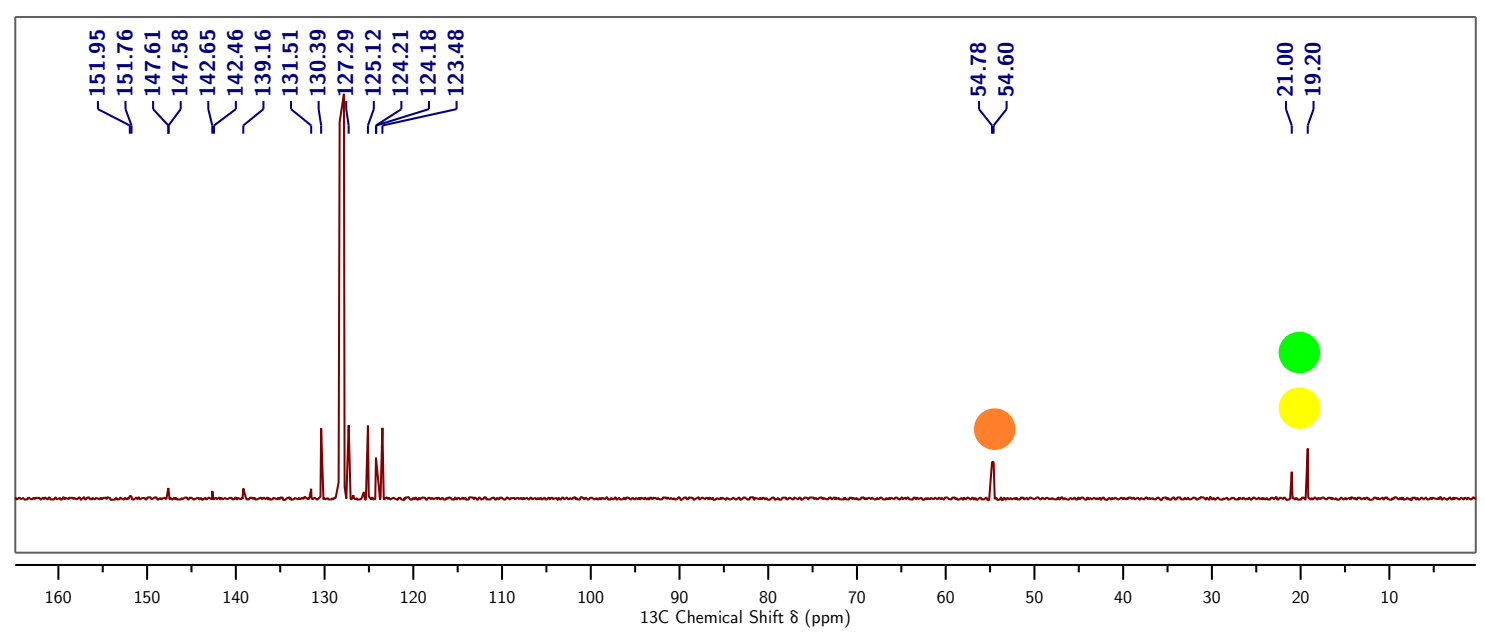

Figure S.3: ${ }^{13} \mathrm{C}\left\{{ }^{1} \mathrm{H}\right\}$ NMR (101 MHz, benzene- $\left.d_{6}, 25{ }^{\circ} \mathrm{C}\right)$ spectrum of 1.

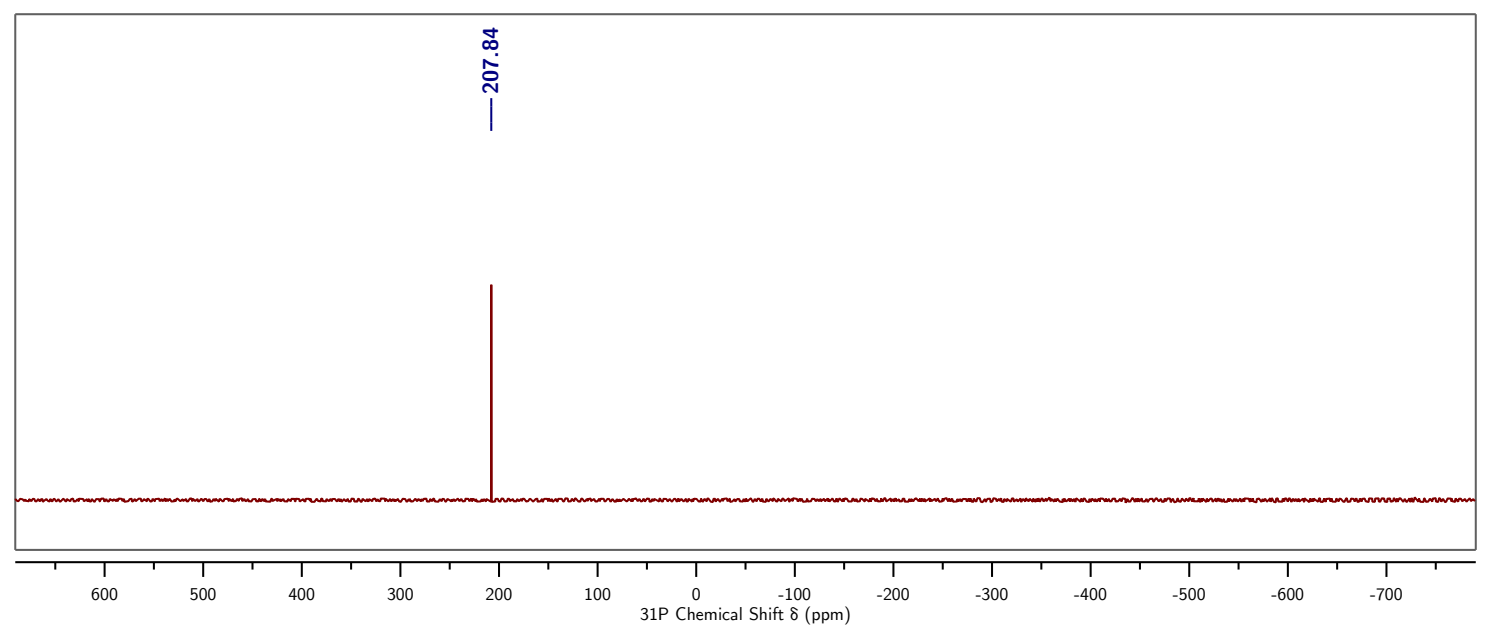

Figure S.4: ${ }^{31} \mathrm{P}\left\{{ }^{1} \mathrm{H}\right\}$ NMR $\left(203 \mathrm{MHz}\right.$, benzene- $\left.d_{6}, 25^{\circ} \mathrm{C}\right)$ spectrum of 1.

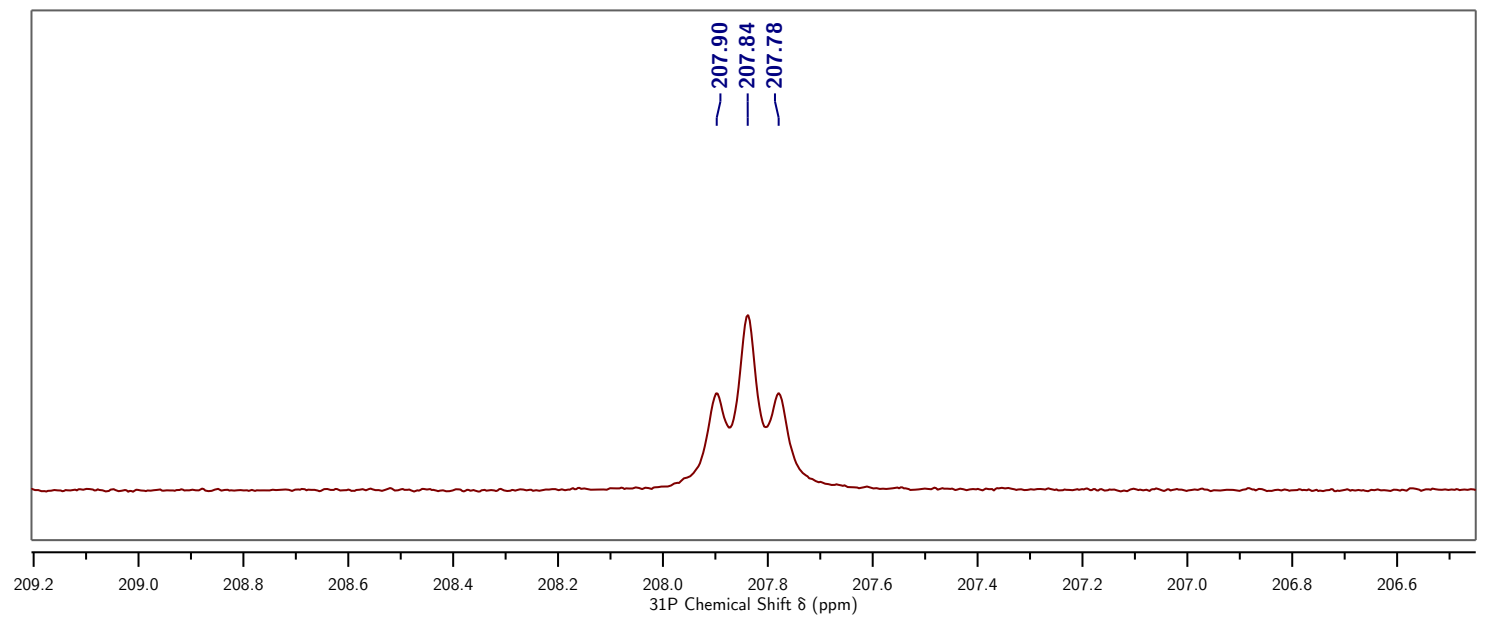

Figure S.5: ${ }^{31} \mathrm{P}$ NMR $\left(203 \mathrm{MHz}\right.$, benzene- $\left.d_{6}, 25^{\circ} \mathrm{C}\right)$ spectrum of $\mathbf{1}$. 

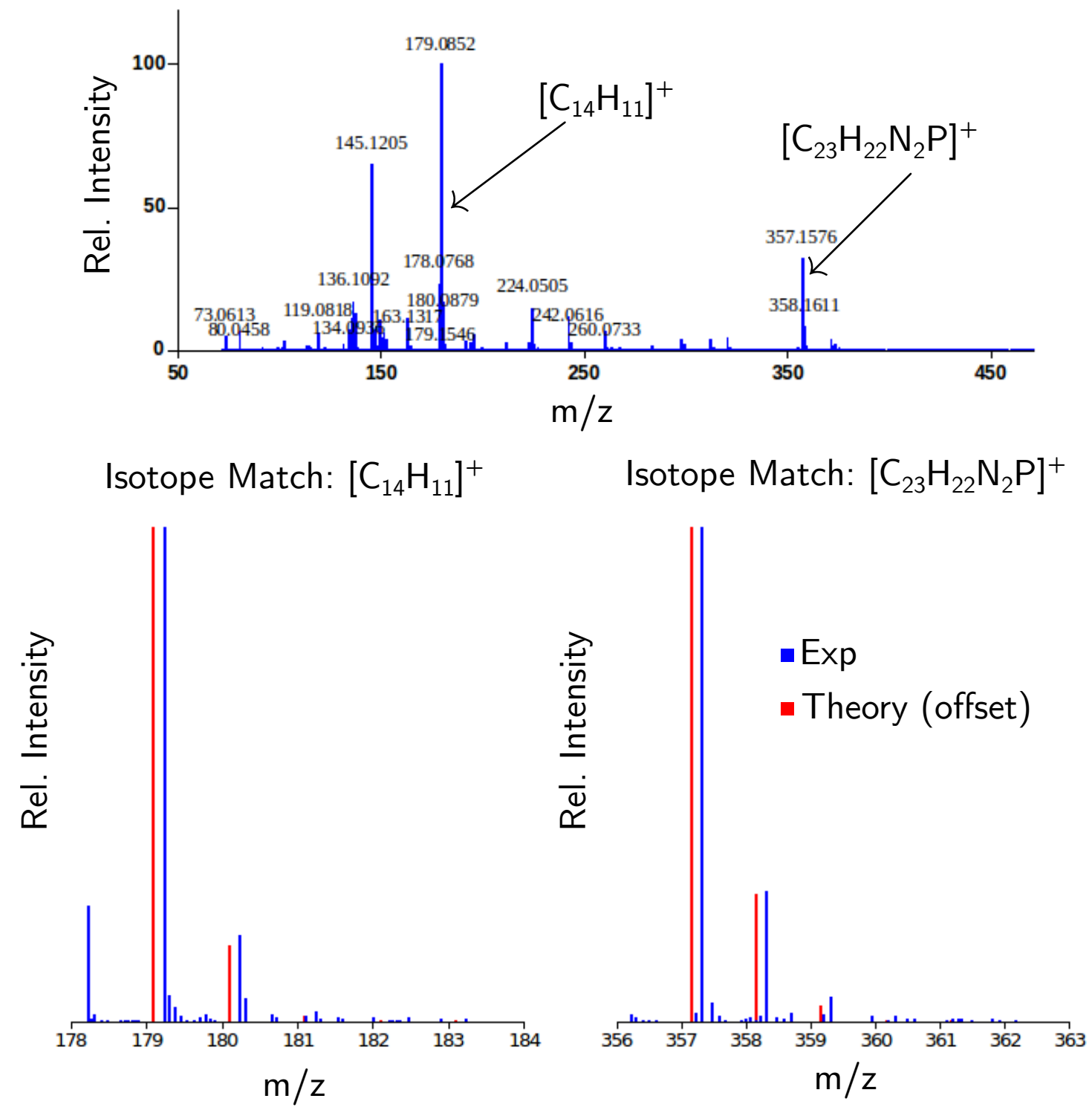

Figure S.6: DART HRMS(Q-TOF) data corresponding to $\left[\mathrm{C}_{23} \mathrm{H}_{22} \mathrm{~N}_{2} \mathrm{P}\right]^{+}$. 


\section{S.1.2.1 Quantification of Conversion using an Internal Standard}

Aluminum foil was used to limit exposure to ambient light during this experiment. A 20 $\mathrm{mL}$ scintillation vial charged with a solution of $\left[\mathrm{Ph}_{3} \mathrm{BPA}\right]\left[\mathrm{Na}\left(\mathrm{OEt}_{2}\right)_{2}\right](200 \mathrm{mg}, 0.322 \mathrm{mmol}$, 1.00 equiv) in THF ( $3 \mathrm{~mL})$ was frozen in the liquid nitrogen cooled coldwell of the glovebox. Separately, a slurry of $\left[\mathrm{MesN}_{2}\right]$ OTf (95 mg, $0.32 \mathrm{mmol}, 1.0$ equiv) in THF (3 mL) was prepared and frozen in the coldwell of the glovebox. Upon thawing, the slurry $\left[\mathrm{MesN}_{2}\right] \mathrm{OTf}$ was added rapidly to the thawing solution of $\left[\mathrm{Ph}_{3} \mathrm{BPA}\right]\left[\mathrm{Na}\left(\mathrm{OEt}_{2}\right)_{2}\right]$. The solution became deep red and homogeneous as it warmed with rapid stirring. After 20 min, acenapthene $(25$ $\mathrm{mg}, 0.16 \mathrm{mmol}, 0.50$ equiv) was added to the stirring solution and an aliquot (ca. $0.5 \mathrm{~mL}$ ) was removed from the reaction mixture and transferred into a $20 \mathrm{~mL}$ scintillation vial. All volatile materials were removed from the aliquot under reduced pressure and the resulting residue was taken up in benzene- $d_{6}(0.7 \mathrm{~mL})$ and filtered through a pipette, containing a plug of glass microfiber filter paper, into an NMR tube. The quantitative ${ }^{1} \mathrm{H}$ NMR spectrum was collected within ten minutes of preparing the NMR sample. Spin-lattice decay constants $\left(T_{1}\right)$ were measured using an inversion recovery pulse sequence and $T_{1}$ times of $3 \mathrm{~s}$ and $5 \mathrm{~s}$ were found for the ethylene proton resonance of acenapthene $\left(2.98 \mathrm{ppm}\right.$ in benzene- $\left.d_{6}\right)$ and the bridgehead proton resonance of $\mathbf{1}\left(4.53 \mathrm{ppm}\right.$ in benzene- $\left.d_{6}\right)$, respectively. The relaxation delay was set to $30 \mathrm{~s}$ to obtain a quantitative ${ }^{1} \mathrm{H}$ NMR spectrum. The ${ }^{1} \mathrm{H}$ NMR spectrum revealed $56 \%$ conversion to $\mathbf{1}$ (Fig. S.7).

\section{S.1.2.2 UV-Visible Spectroscopic Analysis of 1}

Absorption spectral measurements were performed using an Agilent Cary 60 UV-Vis Spectrophotometer equipped with a double beam, Czerny-Turner monochromator and a full spectrum Xenon pulse lamp single source. A quartz cell (sealable with a teflon-lined screw cap) with a path length of $1 \mathrm{~cm}$ was used. The $\mathrm{UV}$-visible spectrum of $\mathrm{MesN}_{2} \mathrm{PA}$ in hexanes $(0.1 \mathrm{mM})$ depicted in Fig. S.8 was collected approximately five minutes after preparing the solution. 


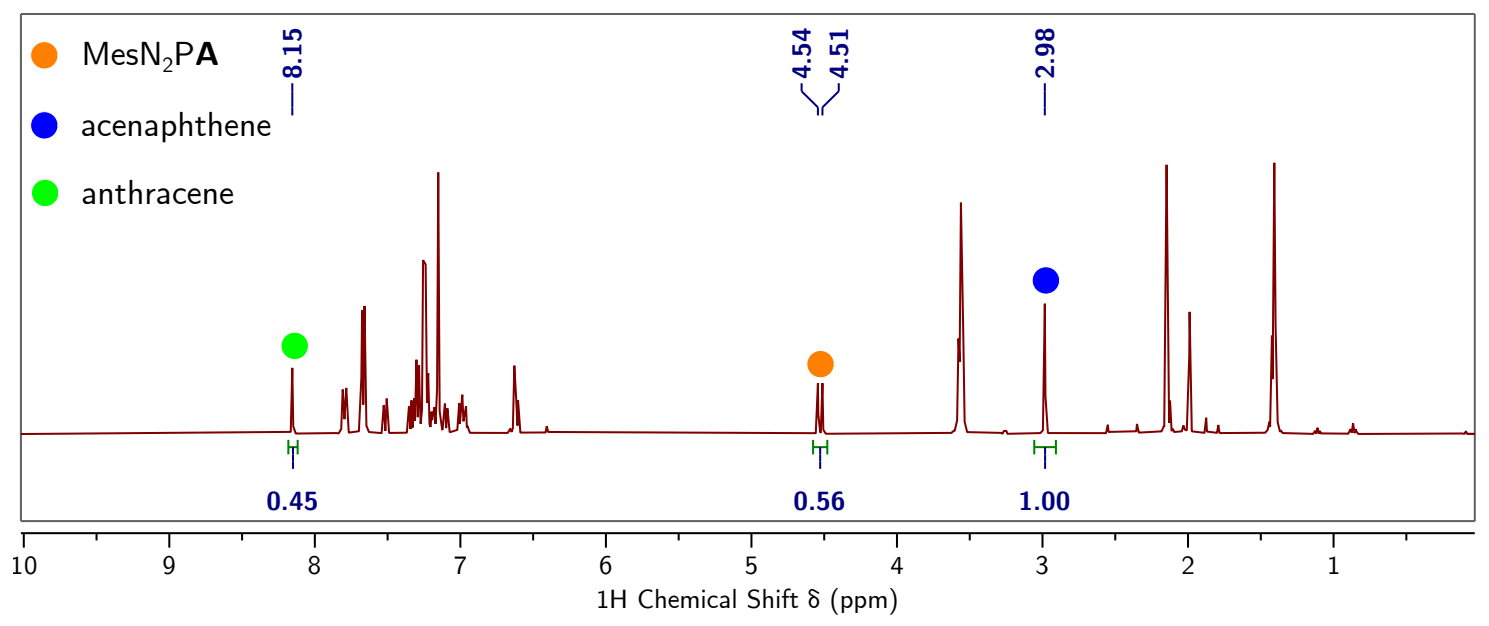

Figure S.7: Quantitative ${ }^{1} \mathrm{H}$ NMR (400 MHz, benzene- $d_{6}, 25{ }^{\circ} \mathrm{C}$ ) spectrum of crude 1 and internal standard acenaphthene.

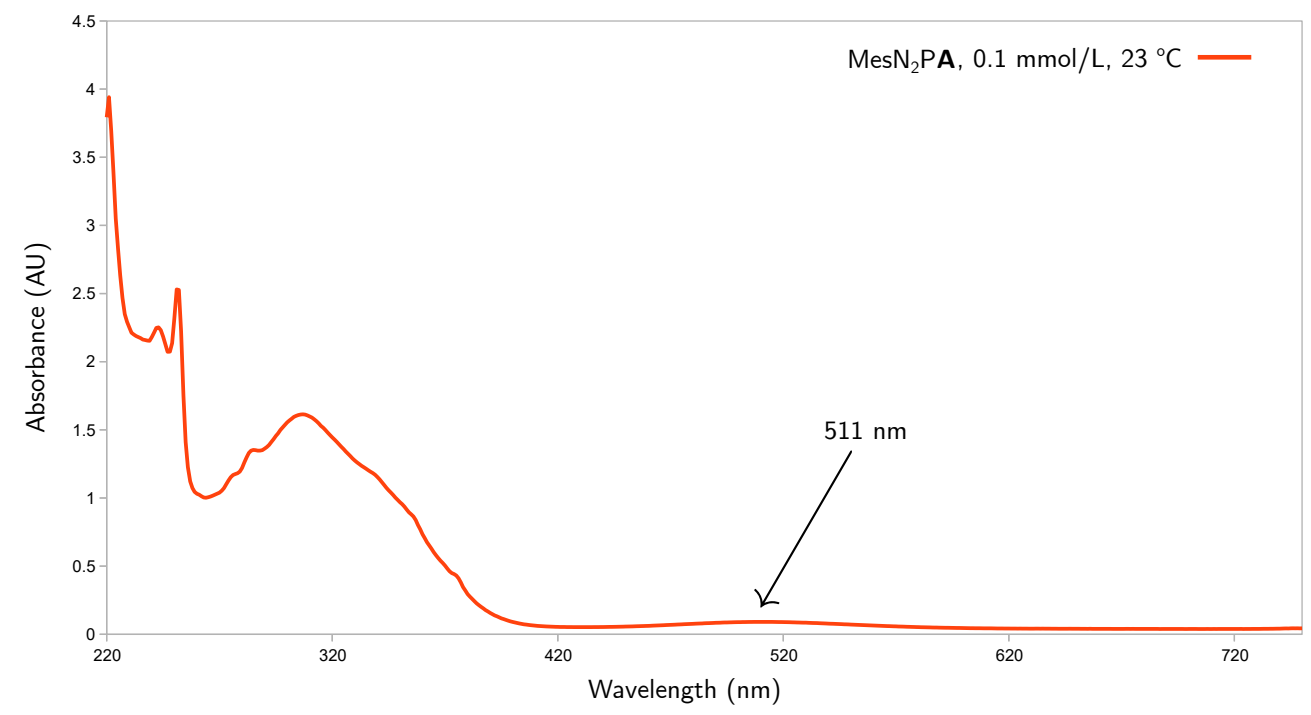

Figure S.8: UV-visible spectrum of 1 in hexanes $(0.1 \mathrm{mM})$ at $23{ }^{\circ} \mathrm{C}$.

\section{S.1.2.3 Air Stability of 1 in Solution}

A 0.03 M solution of 1 in benzene- $d_{6}$ was prepared and transferred to an NMR tube. To this tube was added a glass capillary containing a $0.67 \mathrm{M}$ solution of $\mathrm{Ph}_{3} \mathrm{P}$ in benzene- $d_{6}$ and an initial ${ }^{31} \mathrm{P}\left\{{ }^{1} \mathrm{H}\right\}$ NMR spectrum was collected (Fig. S.9). The cap of the tube was removed outside of the glovebox for a period of $30 \mathrm{~min}$. After this period, a ${ }^{31} \mathrm{P}\left\{{ }^{1} \mathrm{H}\right\} \mathrm{NMR}$ spectrum was collected, revealing complete consumption of $\mathbf{1}$ and the formation of an unknown species. (Fig. S.10). 


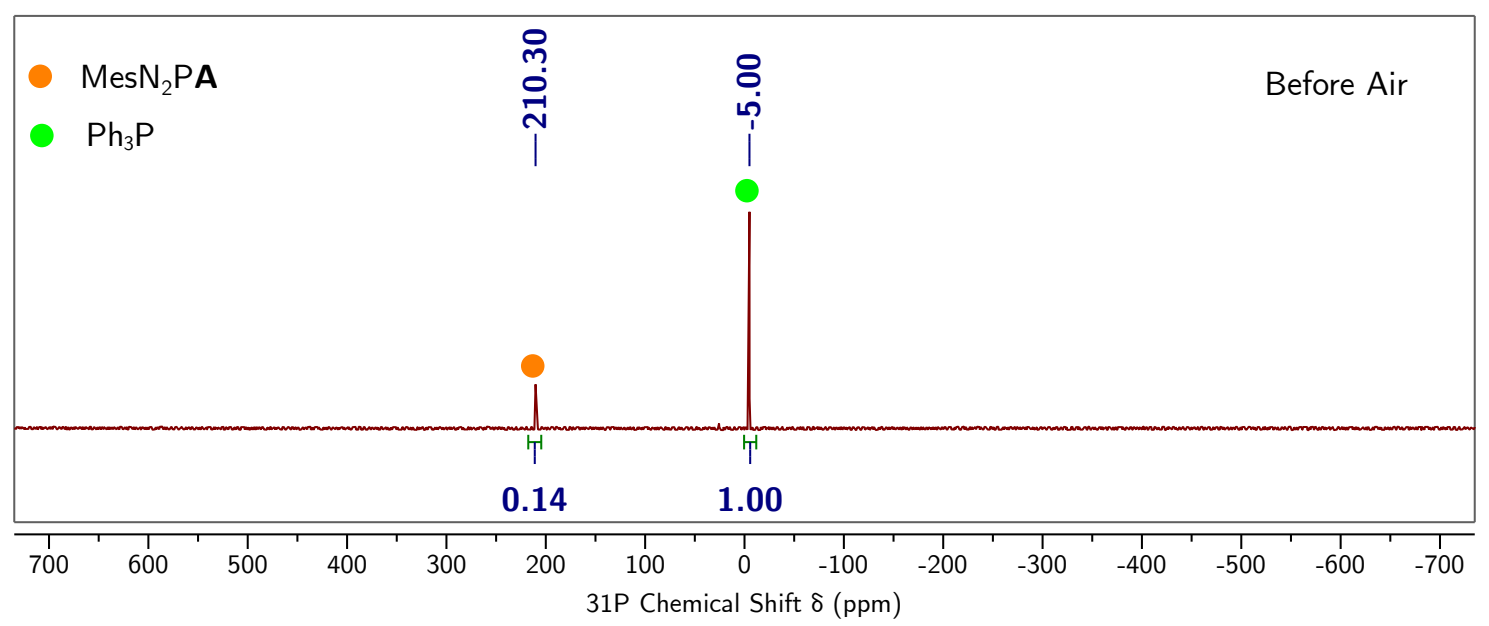

Figure S.9: ${ }^{31} \mathrm{P}\left\{{ }^{1} \mathrm{H}\right\}$ NMR $\left(162 \mathrm{MHz}\right.$, benzene- $\left.d_{6}, 25^{\circ} \mathrm{C}\right)$ spectrum of 1 prior to air exposure.

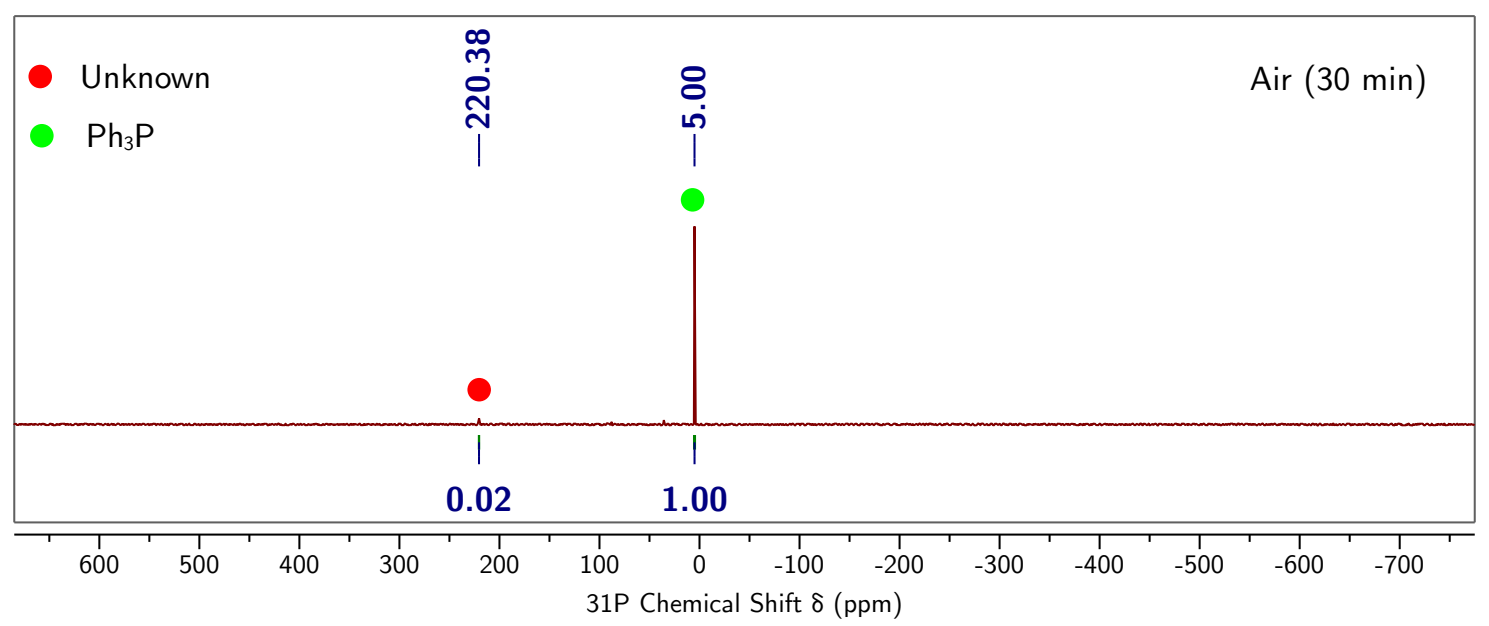

Figure S.10: ${ }^{31} \mathrm{P}\left\{{ }^{1} \mathrm{H}\right\}$ NMR (162 MHz, benzene- $\left.d_{6}, 25{ }^{\circ} \mathrm{C}\right)$ spectrum of $130 \mathrm{~min}$ after air exposure. 


\section{S.1.2.4 Thermal Decomposition of 1 in Solution}

A $0.03 \mathrm{M}$ solution of $\mathbf{1}$ in benzene- $d_{6}$ was prepared and transferred to J Young tube. The tube was removed from the glovebox and initial NMR spectra of the solution were collected (Fig. S.11 and S.12). The tube was then placed in a preheated $60{ }^{\circ} \mathrm{C}$ oil bath for $2 \mathrm{~h}$. NMR spectra of the resulting solution revealed complete consumption of $\mathbf{1}$ and formation of anthracene and broad signals that could correspond to mesityl groups (Fig. S.13 and S.14).

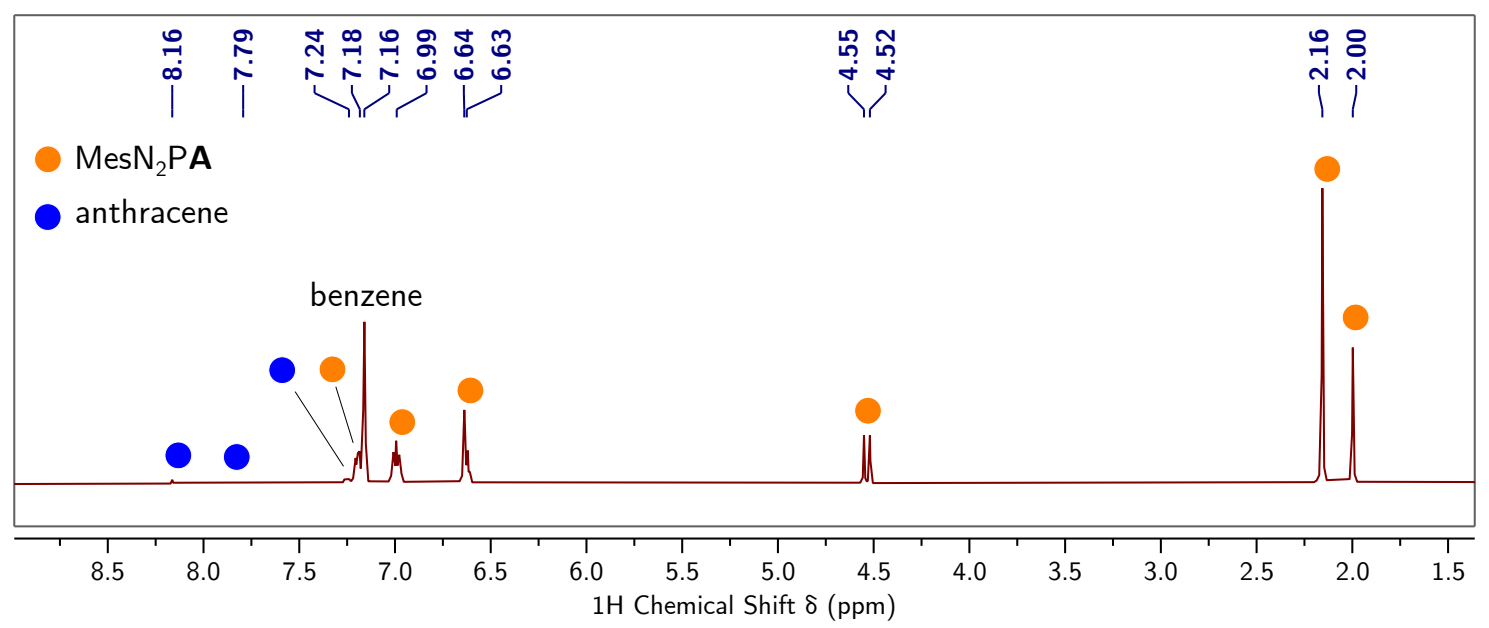

Figure S.11: ${ }^{1} \mathrm{H}$ NMR (400 MHz, benzene- $d_{6}, 25{ }^{\circ} \mathrm{C}$ ) spectrum of $\mathbf{1}$ before heating.

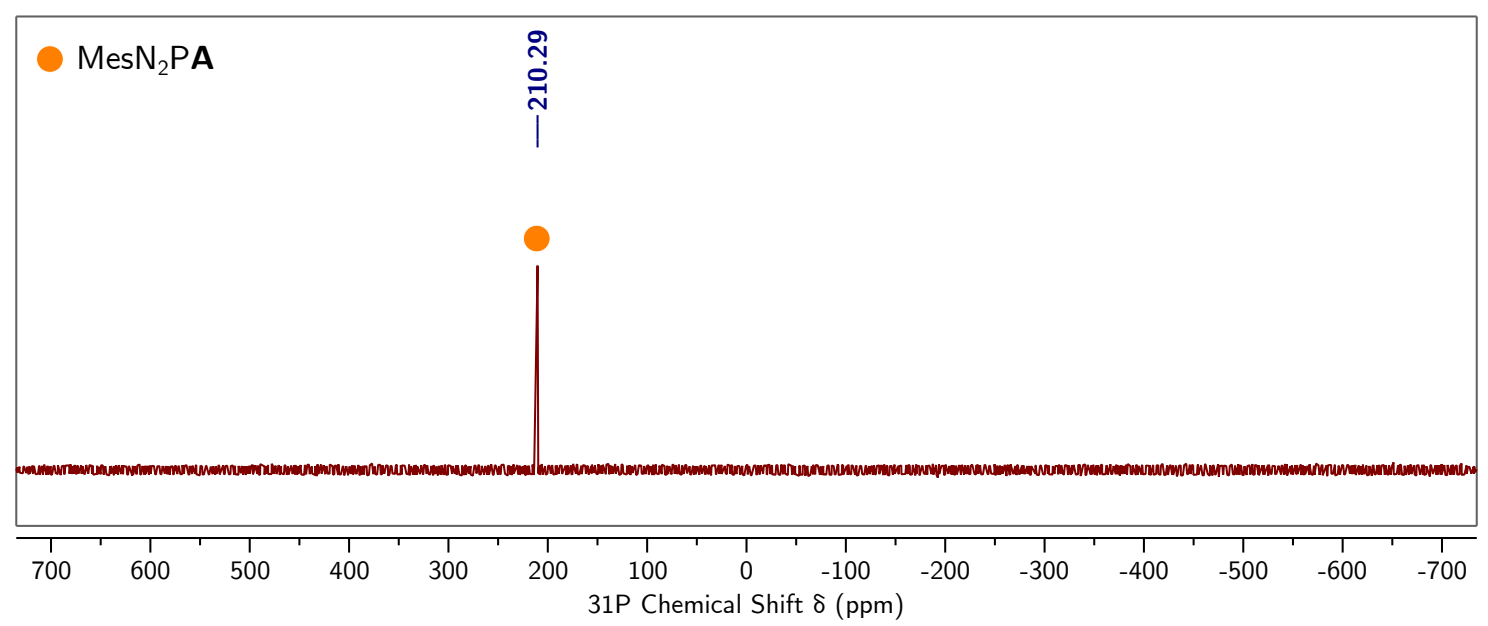

Figure S.12: ${ }^{31} \mathrm{P}\left\{{ }^{1} \mathrm{H}\right\}$ NMR $\left(162 \mathrm{MHz}\right.$, benzene- $\left.d_{6}, 25{ }^{\circ} \mathrm{C}\right)$ spectrum of 1 before heating. 


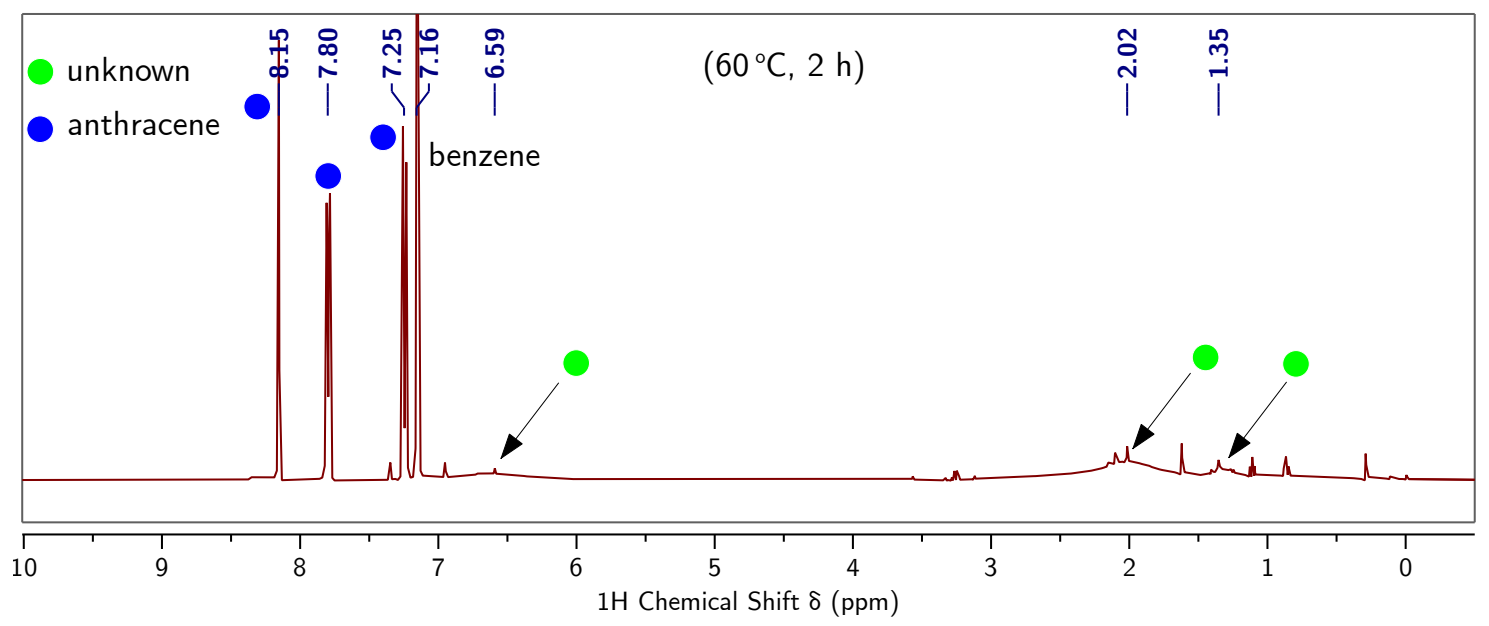

Figure S.13: ${ }^{1} \mathrm{H}$ NMR $\left(400 \mathrm{MHz}\right.$, benzene- $\left.d_{6}, 25^{\circ} \mathrm{C}\right)$ spectrum of $\mathbf{1}$ after heating the solution for $2 \mathrm{~h}$ at $60^{\circ} \mathrm{C}$.

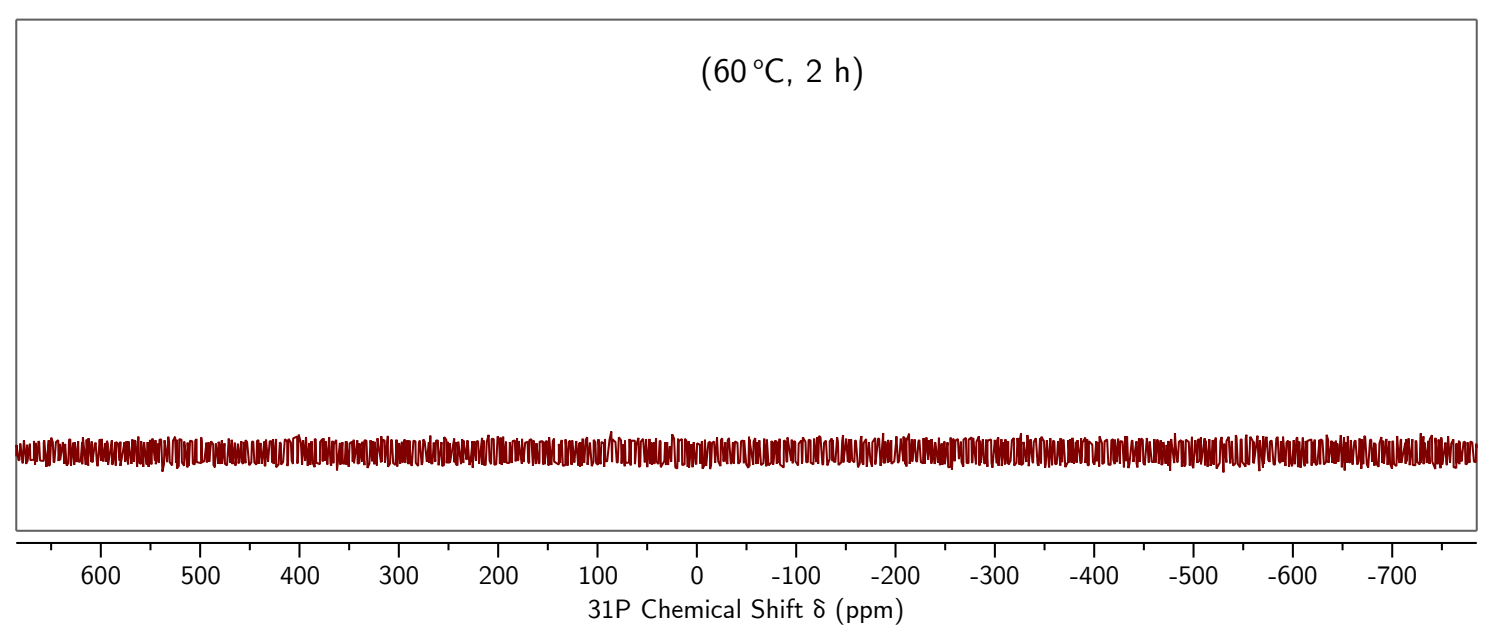

Figure S.14: ${ }^{31} \mathrm{P}\left\{{ }^{1} \mathrm{H}\right\}$ NMR $\left(162 \mathrm{MHz}\right.$, benzene- $\left.d_{6}, 25{ }^{\circ} \mathrm{C}\right)$ spectrum of $\mathbf{1}$ after heating the solution for $2 \mathrm{~h}$ at $60{ }^{\circ} \mathrm{C}$. 


\section{S.1.2.5 Kinetic Study on 1 Thermolysis}

All kinetic studies were performed by ${ }^{1} \mathrm{H}$ NMR spectroscopy on a Bruker Avance Neo 500 spectrometer $\left({ }^{1} \mathrm{H} 500 \mathrm{MHz}\right)$. Temperatures were calibrated with an ethylene glycol thermometer. ${ }^{10}$ Eight-scan spectra were acquired continuously over a period of 3-5 halflives every $110-2100 \mathrm{~s}$, depending on the temperature. Integrals of the $\mathrm{MesN}_{2} \mathrm{PA}$ bridgehead protons were normalized against the methyl protons of internal standard 1,4bis(trimethylsilyl)benzene. Rate constants were extracted from the data using a non-linear least squares method to the first order equation $A=A_{0} e^{-k t}$. In all cases, the fit to this equation was superior to that of the second order equation $A^{-1}=A_{0}^{-1}+2 k t$. The measurements are summarized in Table S.1 and the associated Eyring plot is depicted in Fig. S.15.

Table S.1: Measured rate constants $\left(10^{-5} \mathrm{~s}^{-1}\right)$ for 1 thermolysis at various temperatures.

\begin{tabular}{lllll}
\hline $\operatorname{Exp} / \mathrm{T}(\mathrm{K})$ & 32.9 & 37.6 & 53.0 & 65.3 \\
\hline 1 & 19.3 & 35.4 & 201.9 & 642.4 \\
2 & 20.1 & 35.3 & 183.8 & 662.9 \\
3 & 18.5 & 33.0 & 195.2 & 677.4 \\
Avg & 19.6 & 34.9 & 195.6 & 658.3 \\
Std Dev & 0.8 & 1.2 & 8.5 & 17.7 \\
\hline
\end{tabular}




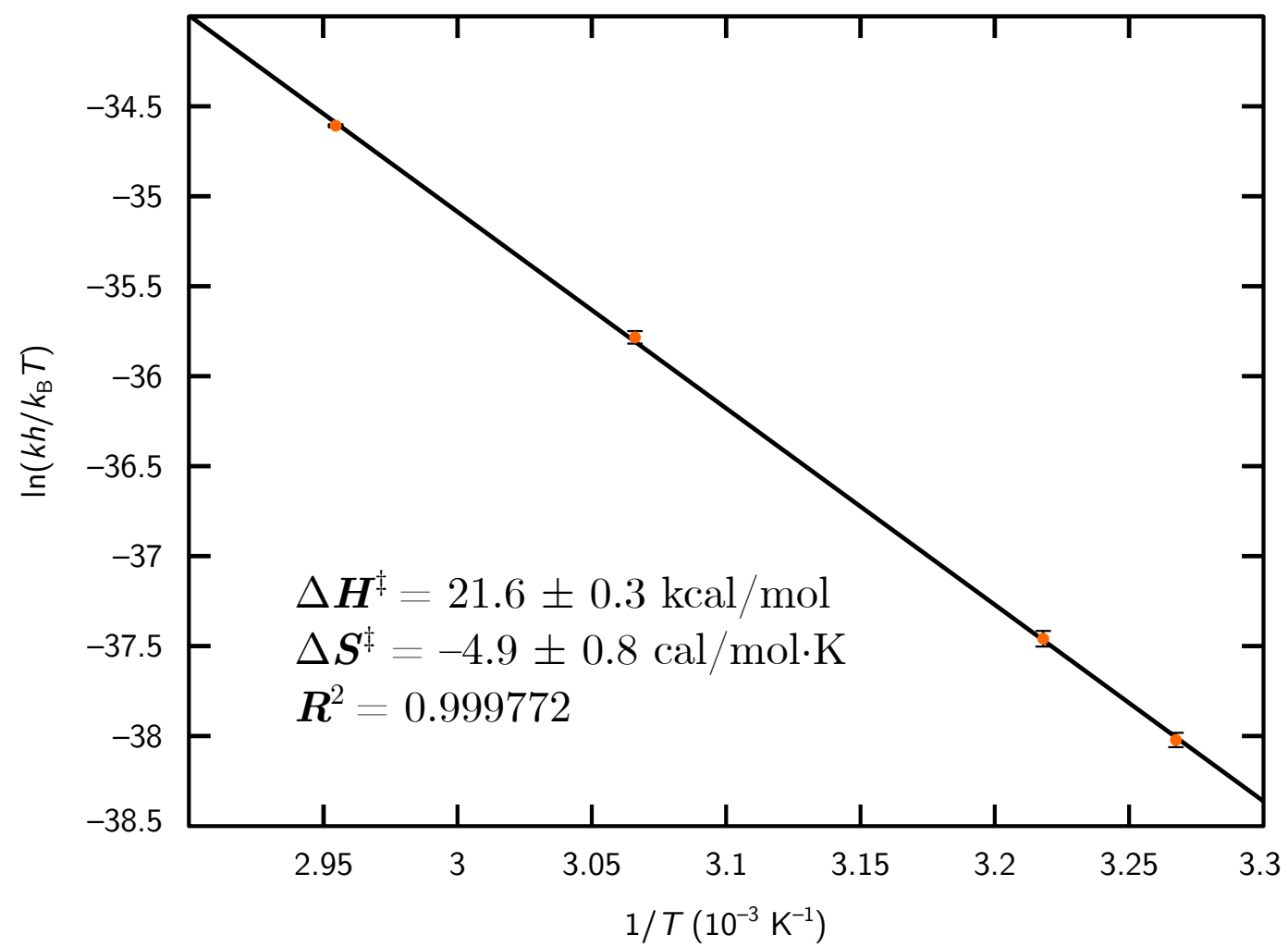

Figure S.15: Eyring plot for the thermolysis of 1 with error bars shown at the $95 \%$ confidence interval using rate constants from monitoring 1 decay by ${ }^{1} \mathrm{H}$ NMR spectroscopy. 


\section{S.1.3 Synthesis of 2 from 1 and Cyclooctyne}

To a stirring solution of $\mathrm{MesN}_{2} \mathrm{PA}(0.050 \mathrm{~g}, 0.14 \mathrm{mmol}, 1.0$ equiv) in benzene $(2 \mathrm{~mL})$ was added cyclooctyne $(0.100 \mathrm{~g}, 1.40 \mathrm{mmol}, 10.0$ equiv) dropwise. After 10 minutes, all volatile materials were removed in vacuo, and to the colorless residue was added pentane $(5 \mathrm{~mL})$. Carefully, the supernatant was filtered through a $15 \mathrm{~mL}$ coarse sintered frit containing a oneinch plug of charcoal and then the plug was washed with THF (6 mL). Removal of volatile materials from the combined filtrates under reduced pressure provided $\mathbf{2}$ as a colorless oil (0.026 g, $0.091 \mathrm{mmol}, 65 \%$ ). DART HRMS(Q-TOF) m/z: $[\mathrm{M}+\mathrm{H}]^{+}$Calcd for $\mathrm{C}_{17} \mathrm{H}_{24} \mathrm{~N}_{2} \mathrm{P}$ 287.1677; found 287.1682 (Fig. S.21) ${ }^{1} \mathrm{H}$ NMR (500 MHz, chloroform- $d, 25{ }^{\circ} \mathrm{C}$, Fig. S.17) $\delta$ $6.94(\mathrm{~s}, 2 \mathrm{H}) 2.87(\mathrm{dt}, 2 \mathrm{H}), 2.63-2.53(\mathrm{t}, 2 \mathrm{H}), 2.33(\mathrm{~s}, 3 \mathrm{H}), 1.85(\mathrm{~s}, 6 \mathrm{H}), 1.72(\mathrm{~b}, 2 \mathrm{H}), 1.42(\mathrm{~b}$, 6H). ${ }^{13} \mathrm{C}\left\{{ }^{1} \mathrm{H}\right\}$ NMR (126 MHz, chloroform- $d, 25{ }^{\circ} \mathrm{C}$, Fig. S.18) $\delta 152.56\left(\mathrm{~d}, J_{\mathrm{PC}}=11.2 \mathrm{~Hz}\right)$, $152.32\left(\mathrm{~d}, J_{\mathrm{PC}}=46.4 \mathrm{~Hz}\right), 138.95,138.90,135.26,129.19,33.37\left(\mathrm{~d}, J_{\mathrm{PC}}=3.1 \mathrm{~Hz}\right), 28.31$, $25.73\left(\mathrm{~d}, J_{\mathrm{PC}}=19.4 \mathrm{~Hz}\right), 25.35\left(\mathrm{~d}, J_{\mathrm{PC}}=16.2 \mathrm{~Hz}\right), 24.66\left(\mathrm{~d}, J_{\mathrm{PC}}=3.2 \mathrm{~Hz}\right), 21.28,17.20$ ppm. ${ }^{31} \mathrm{P}\left\{{ }^{1} \mathrm{H}\right\}$ NMR (203 MHz, chloroform- $d, 25{ }^{\circ} \mathrm{C}$, Fig. S.19) $\delta 227.24$ ppm. ${ }^{31} \mathrm{P}$ NMR $\left(203 \mathrm{MHz}\right.$, chloroform- $d, 25{ }^{\circ} \mathrm{C}$, Fig. S.20) $\delta 227.24\left({ }^{1} J_{\mathrm{PH}}=10.2 \mathrm{~Hz}\right) \mathrm{ppm}$.

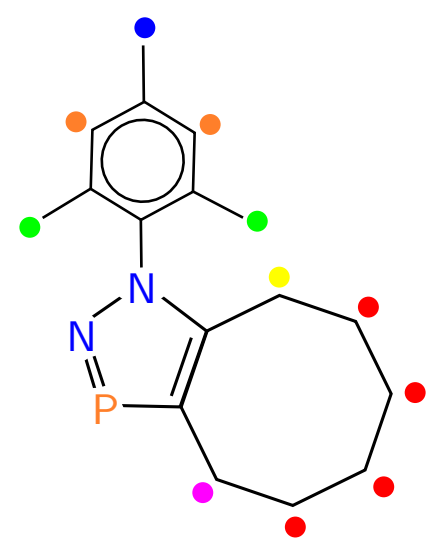

Figure S.16: Labeling scheme for 2. 


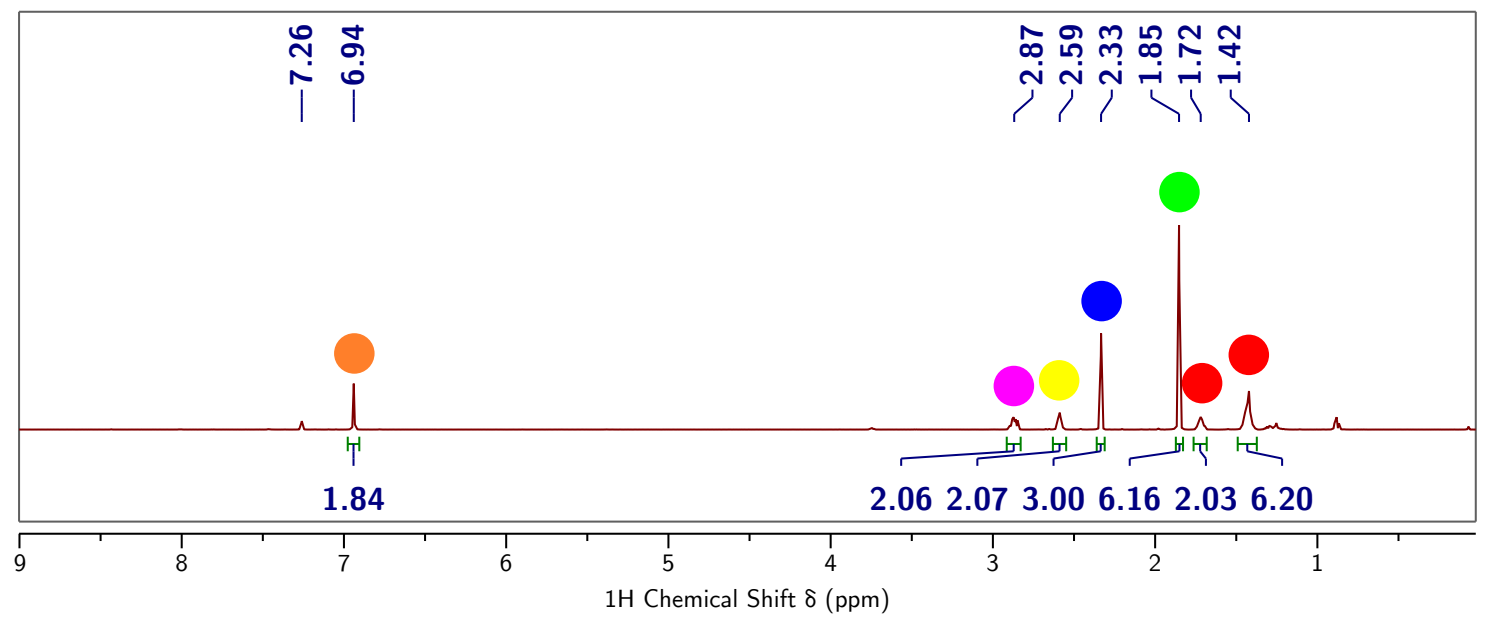

Figure S.17: ${ }^{1} \mathrm{H}$ NMR (500 MHz, chloroform- $d, 25{ }^{\circ} \mathrm{C}$ ) spectrum of $\mathbf{2}$ with residual pentane.

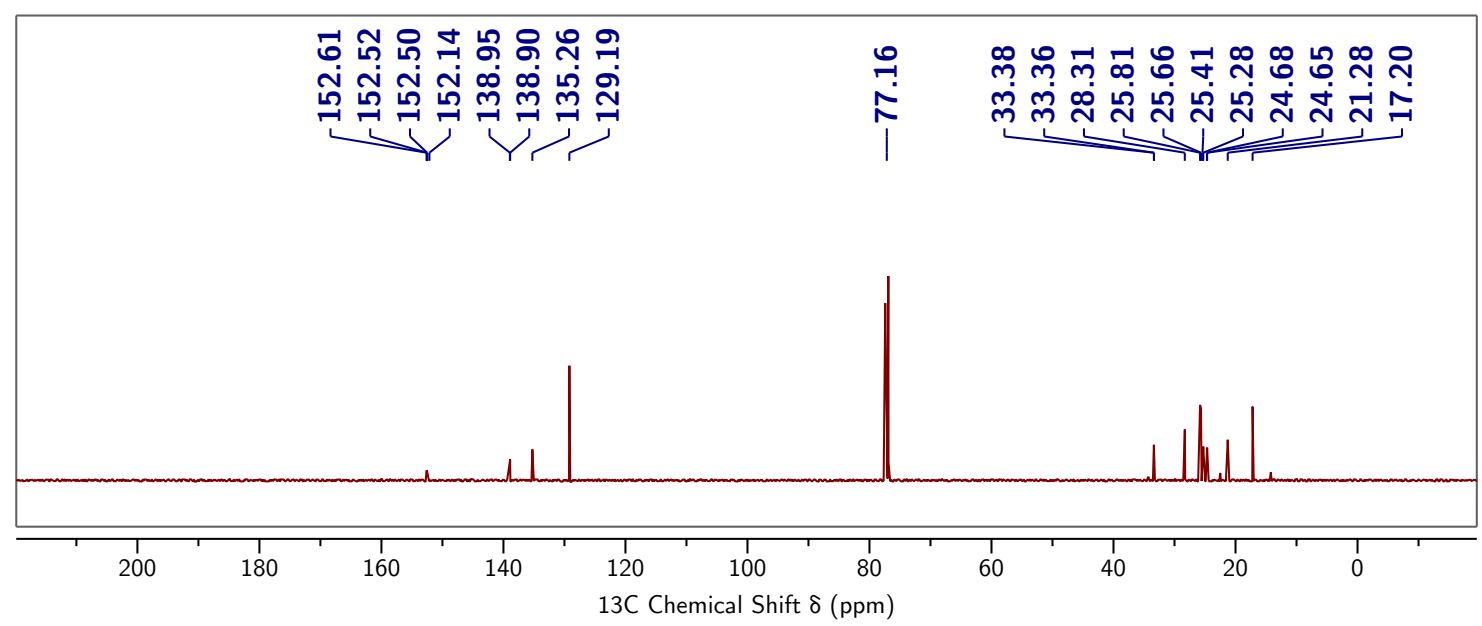

Figure S.18: ${ }^{13} \mathrm{C}\left\{{ }^{1} \mathrm{H}\right\}$ NMR (126 MHz, chloroform- $\left.d, 25{ }^{\circ} \mathrm{C}\right)$ spectrum of 2 with residual pentane.

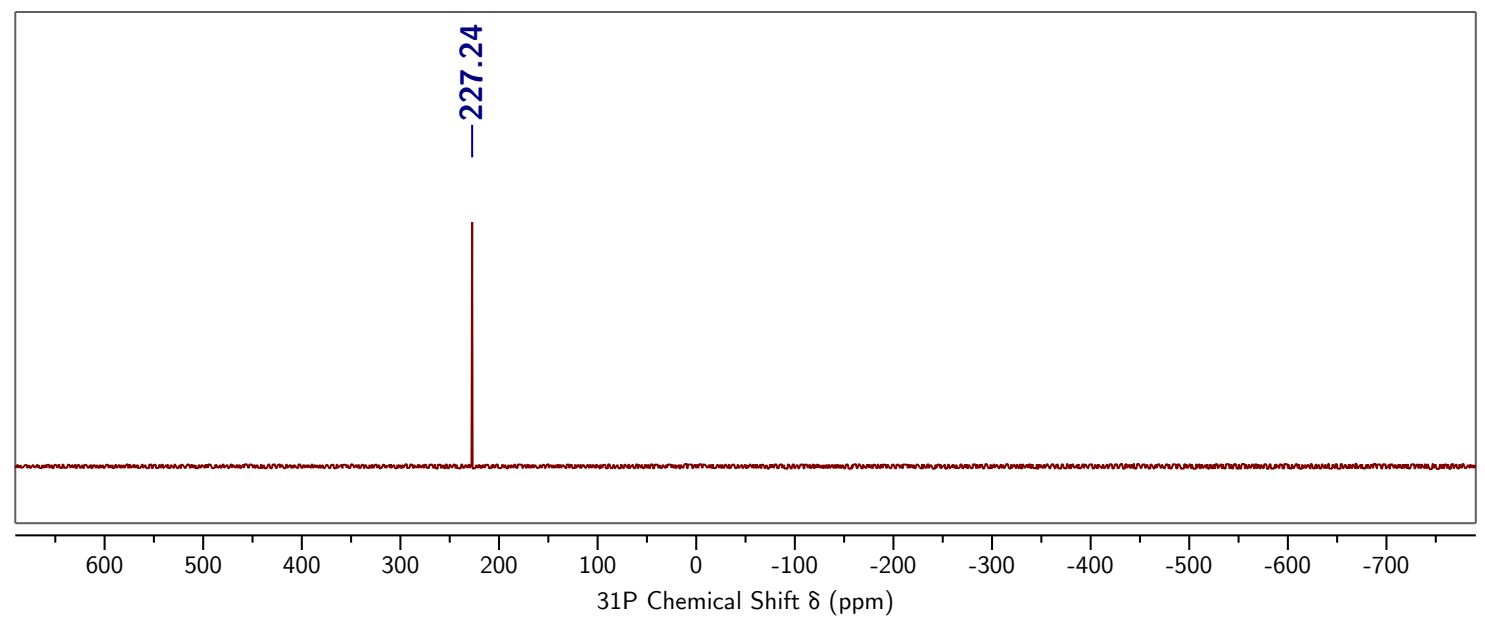

Figure S.19: ${ }^{31} \mathrm{P}\left\{{ }^{1} \mathrm{H}\right\}$ NMR (203 MHz, chloroform-d, $\left.25^{\circ} \mathrm{C}\right)$ spectrum of 2. 


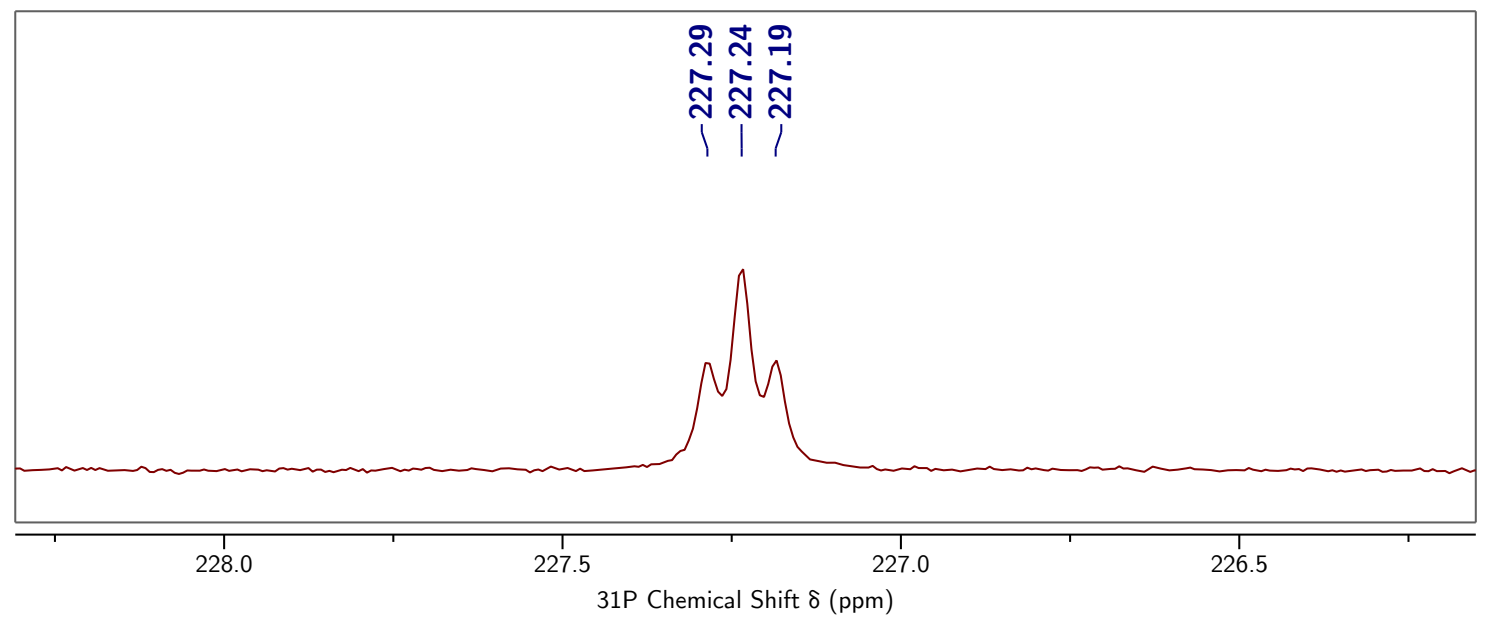

Figure S.20: ${ }^{31} \mathrm{P}$ NMR (203 MHz, chloroform- $d, 25^{\circ} \mathrm{C}$ ) spectrum of 2.

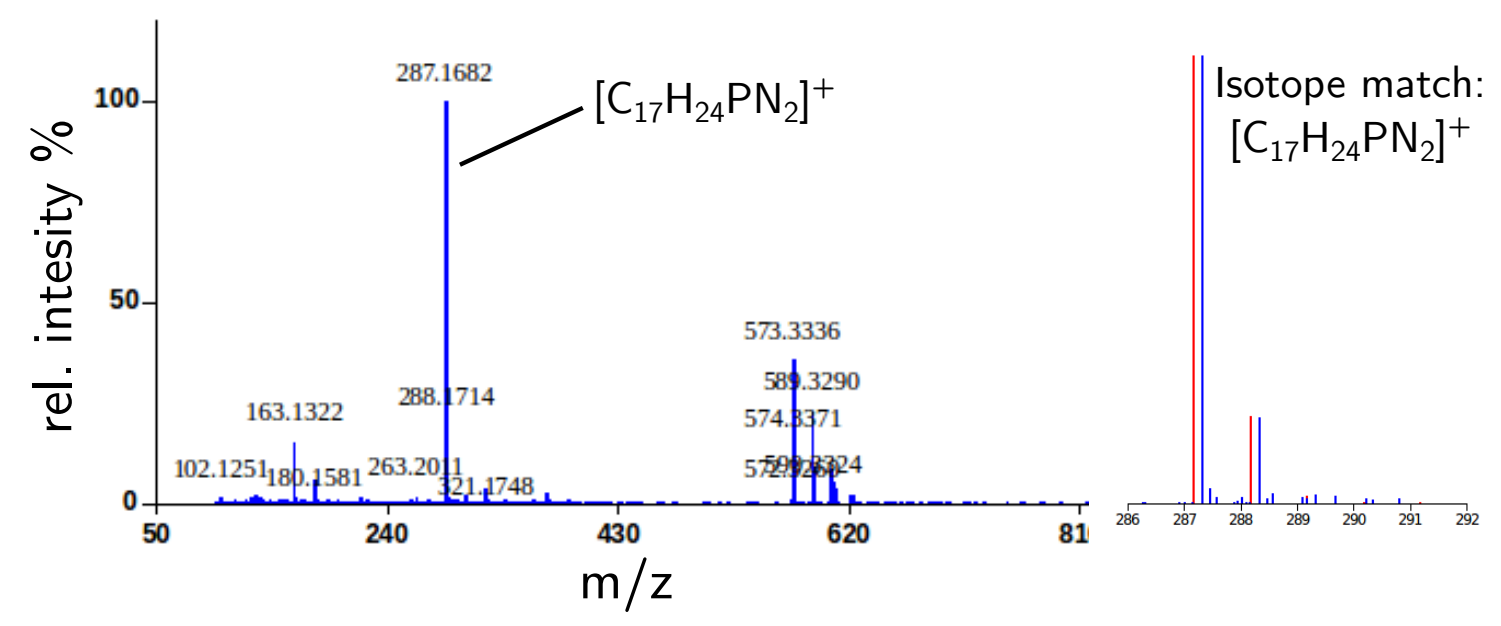

Figure S.21: DART HRMS(Q-TOF) data corresponding to $\left[\mathrm{C}_{17} \mathrm{H}_{24} \mathrm{PN}_{2}\right]^{+}$. 


\section{S.1.4 Synthesis of $\quad[3]\left[\mathrm{Na}(12 \text {-crown- } 4)_{2}\right] \quad$ from $\left.[\mathrm{Na} \text { (dioxane })_{2.5}\right][\mathrm{OCP}]$ and 1}

Aluminum foil was used to limit exposure to ambient light during this experiment. To a stirring solution of 1 (0.100 g, $0.280 \mathrm{mmol}, 1$ equiv) in THF (4 mL) was added $\left.[\mathrm{Na} \text { (dioxane })_{2.5}\right][\mathrm{OCP}](0.084 \mathrm{~g}, 0.28 \mathrm{mmol}, 1$ equiv $)$ portionwise. The reaction mixture stirred for two hours, during which the color of the solution faded from bright purple to pale orange. 12-Crown-4 (0.099 g, $0.56 \mathrm{mmol}, 2$ equiv) was added dropwise to this solution, causing a white solid to precipitate. The white solids were collected by filtration using a $15 \mathrm{~mL}$ medium sintered frit, washed with $\mathrm{Et}_{2} \mathrm{O}(4 \mathrm{~mL})$, and dried in vacuo. Crystallization from $\mathrm{MeCN}$ at $-35{ }^{\circ} \mathrm{C}$ provided colorless plates of $[3]\left[\mathrm{Na}(12 \text {-crown-4) })_{2}\right](0.083 \mathrm{~g}, 0.14$ mmol, 49 \%). DART HRMS(Q-TOF) m/z: [M] $]^{-}$Calcd for $\mathrm{C}_{10} \mathrm{H}_{11} \mathrm{~N}_{2} \mathrm{P}_{2} \mathrm{O}$ 237.0352; Found 237.0394 (Fig. S.28). Elem. Anal. Found(Calc'd) for $\mathrm{C}_{26} \mathrm{H}_{43} \mathrm{~N}_{2} \mathrm{O}_{9} \mathrm{P}_{2} \mathrm{Na}, \mathrm{C}, 50.98(50.38) ; \mathrm{H}$, 7.08 (6.93); N, 4.57(4.05) ${ }^{1} \mathrm{H}$ NMR $\left(500 \mathrm{MHz}\right.$, acetonitrile- $d_{3}, 25^{\circ} \mathrm{C}$, Fig. S.23) $\delta 6.90(\mathrm{~s}, 2 \mathrm{H})$, $3.62(\mathrm{~s}, 32 \mathrm{H}), 2.29(\mathrm{~s}, 3), 1.92(\mathrm{~s}, 6 \mathrm{H}) \mathrm{ppm} .{ }^{13} \mathrm{C}\left\{{ }^{1} \mathrm{H}\right\}$ NMR $\left(126 \mathrm{MHz}\right.$, acetonitrile- $d_{3}, 25{ }^{\circ} \mathrm{C}$, Fig. S.24) $\delta 199.24\left(\mathrm{~d},{ }^{1} J_{\mathrm{PC}}=74.5 \mathrm{~Hz}\right), 142.55,137.51,136.68,129.00,67.09,21.11,17.83$ ppm. ${ }^{31} \mathrm{P}\left\{{ }^{1} \mathrm{H}\right\}$ NMR $\left(203 \mathrm{MHz}\right.$, chloroform- $d, 25{ }^{\circ} \mathrm{C}$, Fig. S.25) $\delta 331.51\left(\mathrm{~d},{ }^{1} J_{\mathrm{PP}}=449 \mathrm{~Hz}\right)$, $96.99\left(\mathrm{~d},{ }^{1} J_{\mathrm{PP}}=449 \mathrm{~Hz}\right) \mathrm{ppm}$.

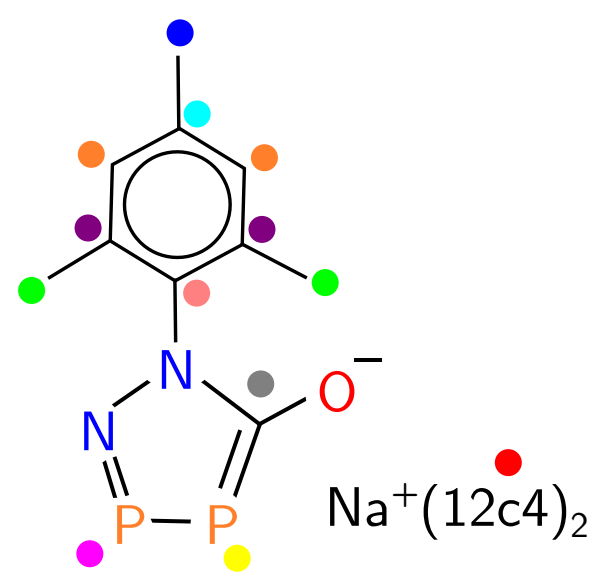

Figure S.22: Labeling scheme for $[\mathbf{3}]\left[\mathrm{Na}(12 \text {-crown-4) })_{2}\right]$. 


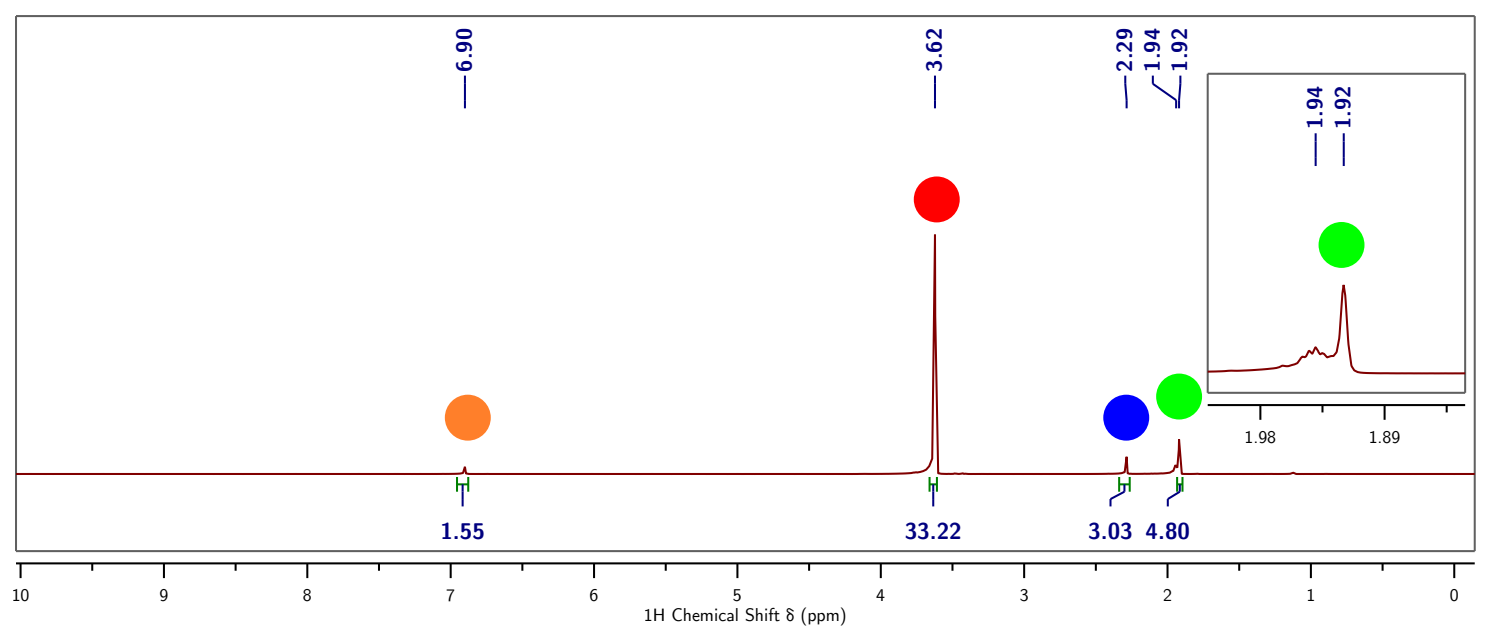

Figure S.23: ${ }^{1} \mathrm{H}$ NMR $\left(500 \mathrm{MHz}\right.$, acetonitrile- $\left.d_{3}, 25{ }^{\circ} \mathrm{C}\right)$ spectrum of $[3]\left[\mathrm{Na}(12 \text {-crown-4) })_{2}\right]$.

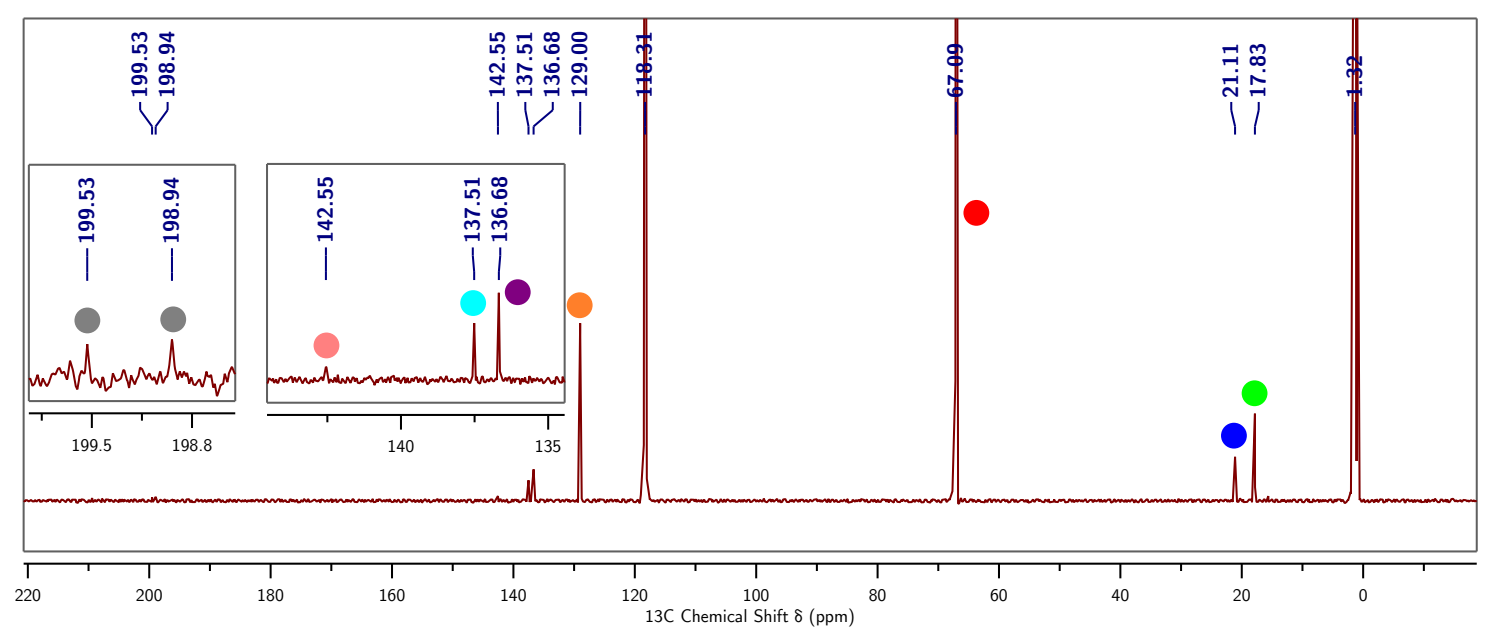

Figure S.24: ${ }^{13} \mathrm{C}\left\{{ }^{1} \mathrm{H}\right\}$ NMR $\left(126 \mathrm{MHz}\right.$, acetonitrile- $\left.d_{3}, 25{ }^{\circ} \mathrm{C}\right)$ spectrum of $[3][\mathrm{Na}(12$-crown$\left.4)_{2}\right]$. 


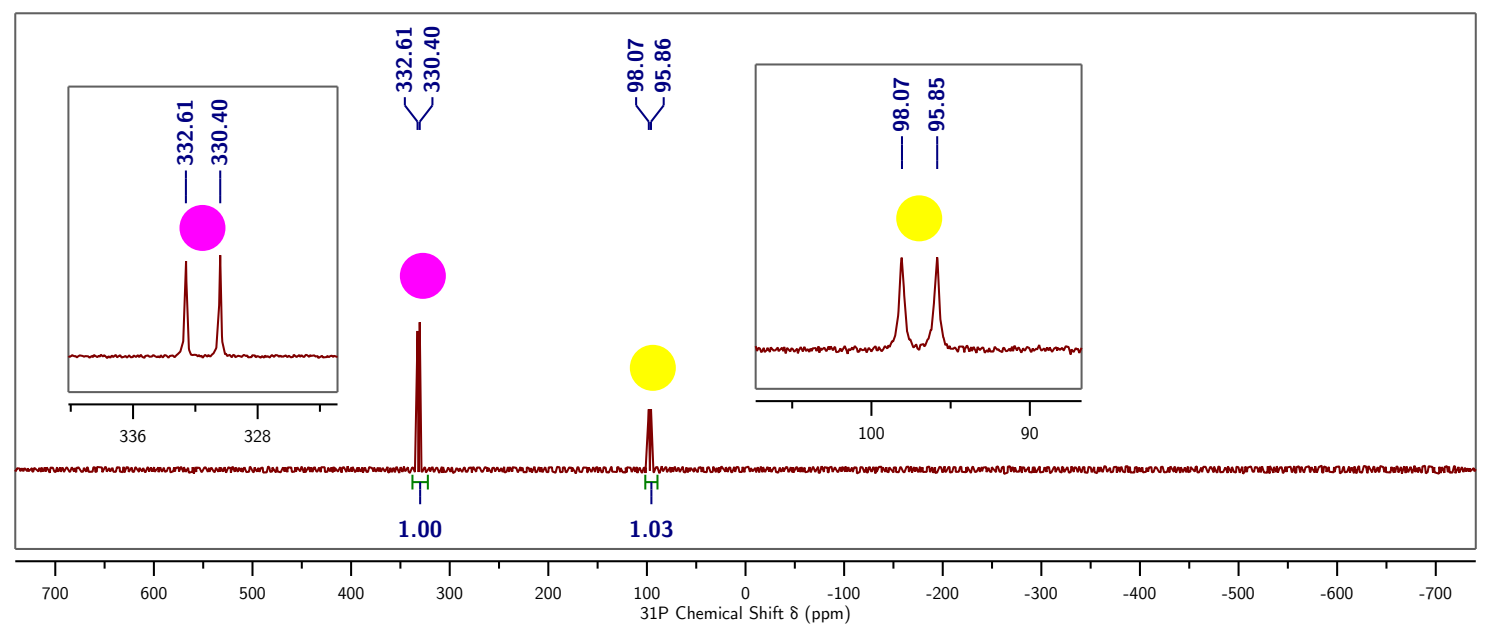

Figure S.25: ${ }^{31} \mathrm{P}\left\{{ }^{1} \mathrm{H}\right\}$ NMR (203 MHz, chloroform- $\left.d, 25{ }^{\circ} \mathrm{C}\right)$ spectrum of $[3][\mathrm{Na}(12$-crown$\left.4)_{2}\right]$.

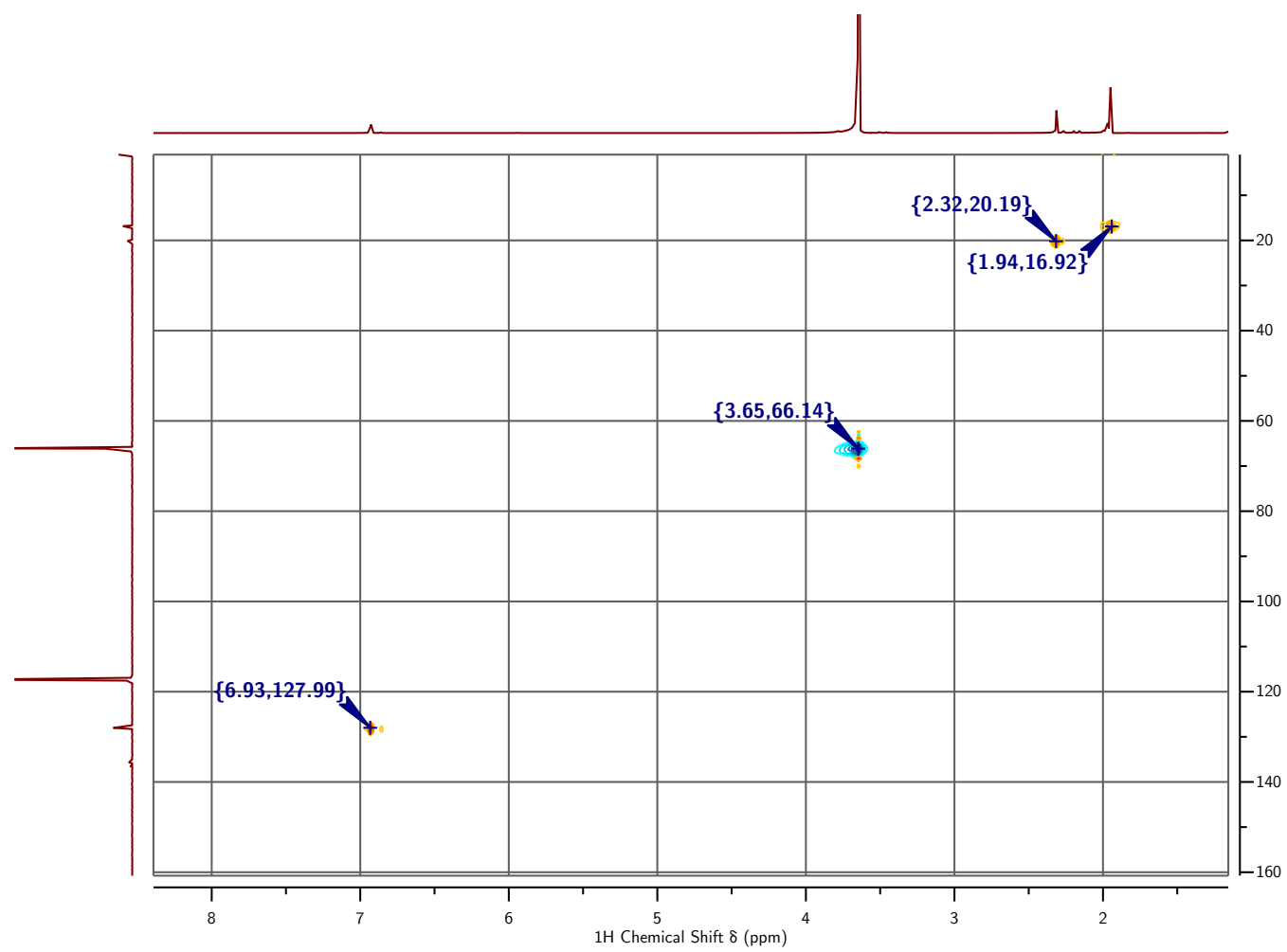

Figure S.26: ${ }^{1} \mathrm{H},{ }^{13} \mathrm{C}-\mathrm{HSQC}$ NMR $\left(500 \mathrm{MHz}\right.$, acetonitrile- $\left.d_{3}, 25{ }^{\circ} \mathrm{C}\right)$ spectrum of $[\mathbf{3}][\mathrm{Na}(12$ crown-4) 2 . 


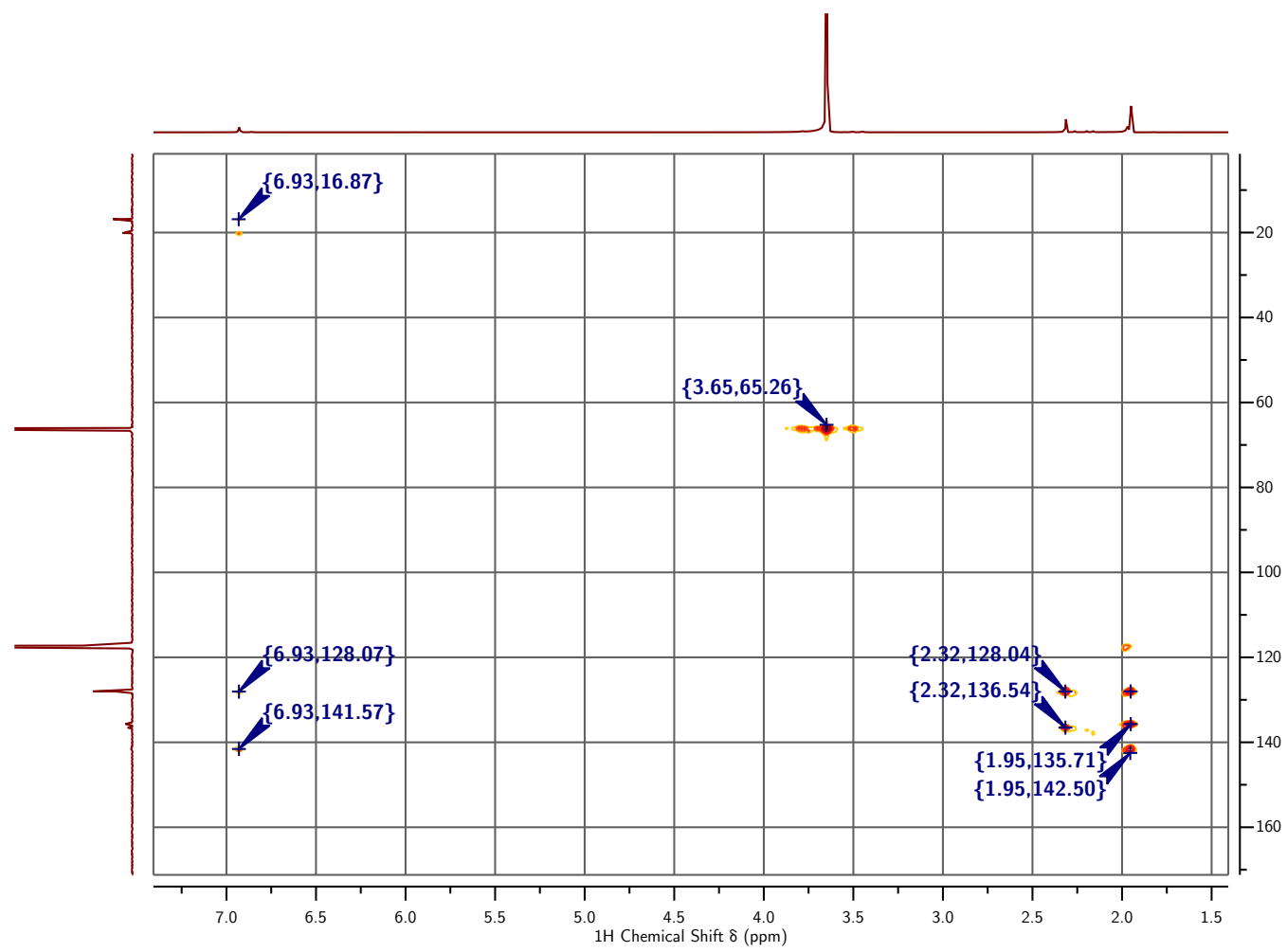

Figure S.27: ${ }^{1} \mathrm{H},{ }^{13} \mathrm{C}-\mathrm{HMBC} \mathrm{NMR}\left(500 \mathrm{MHz}\right.$, acetonitrile- $\left.d_{3}, 25{ }^{\circ} \mathrm{C}\right)$ spectrum of $[3][\mathrm{Na}(12$ crown-4) 2 . 


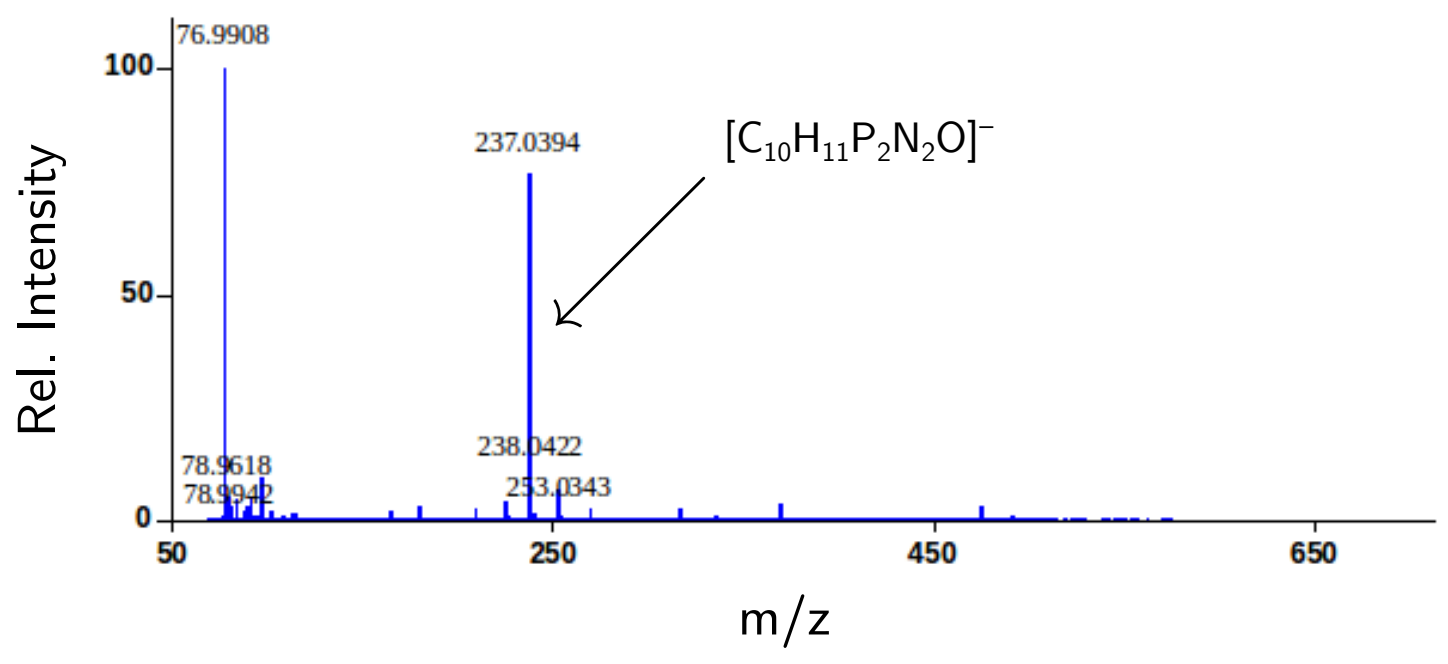

Isotope Match: $\left[\mathrm{C}_{10} \mathrm{H}_{11} \mathrm{P}_{2} \mathrm{~N}_{2} \mathrm{O}\right]^{-}$

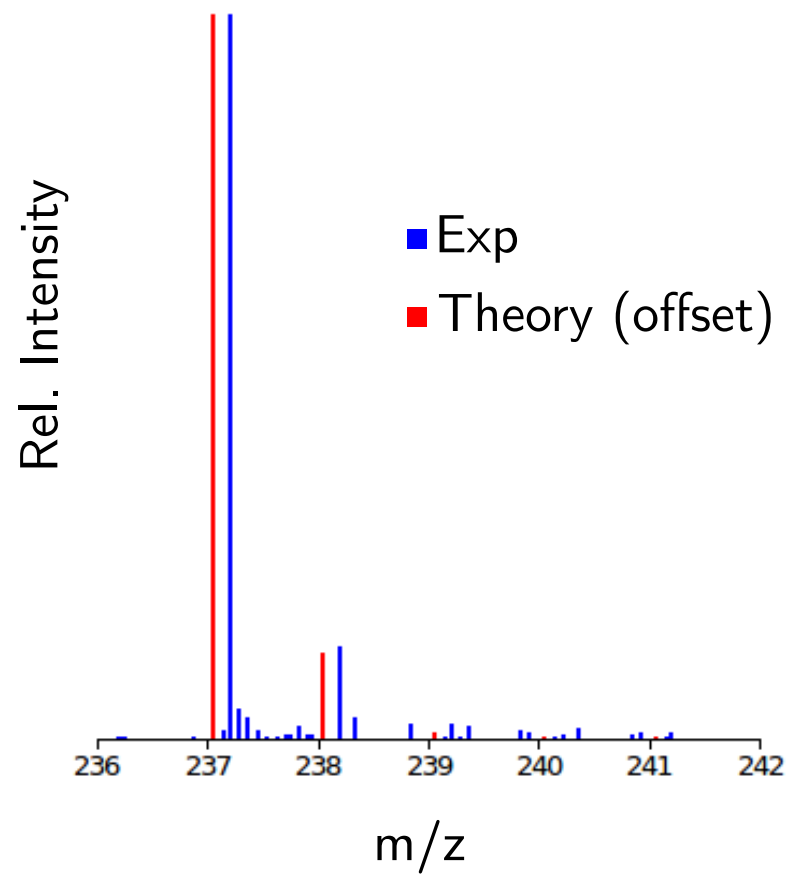

Figure S.28: DART HRMS(Q-TOF) data corresponding to $\left[\mathrm{C}_{10} \mathrm{H}_{11} \mathrm{P}_{2} \mathrm{~N}_{2} \mathrm{O}\right]^{-}$. 


\section{S.1.5 Synthesis of 4 from 1 and 1-Adamantylphosphaethyne}

Aluminum foil was used to limit exposure to ambient light during this experiment. To a stirring solution of $\mathrm{MesN}_{2} \mathrm{PA}(0.060 \mathrm{~g}, 0.17 \mathrm{mmol}, 1.2$ equiv) in THF (2 mL) was added 1-adamantylphosphaethyne $(0.025 \mathrm{~g}, 0.14,1.0$ equiv) in one portion. After 12 hours, all volatile materials were removed in vacuo. The resulting pale yellow solids were taken up in pentane $(2 \mathrm{~mL})$ and the slurry was loaded onto a glass microfiber filter paper plugged pipette containing a one-inch plug of charcoal. The plug was washed with diethyl ether $(3 \mathrm{~mL})$ and all volatile materials were removed from the combined filtrates under reduced pressure, affording 4 as a pale yellow oil $(0.023 \mathrm{~g}, 0.064 \mathrm{mmol}, 38 \%)$. DART HRMS(QTOF) m/z: $[\mathrm{M}+\mathrm{H}]^{+}$Calcd for $\mathrm{C}_{20} \mathrm{H}_{27} \mathrm{~N}_{2} \mathrm{P}_{2}$ 357.1709; found 357.1650 (Fig. S.35) ${ }^{1} \mathrm{H}$ NMR (400 MHz, chloroform- $d, 25{ }^{\circ} \mathrm{C}$, Fig. S.30) $\delta 6.96(\mathrm{~s}, 2 \mathrm{H}), 2.34(\mathrm{~s}, 3 \mathrm{H}) 2.16$ (d, 6H), $1.93(\mathrm{~s}$, 3H), 1.93 (s, 6H), 1.81 (t, 6H) ppm. ${ }^{13} \mathrm{C}\left\{{ }^{1} \mathrm{H}\right\}$ NMR (101 MHz, chloroform-d, $25{ }^{\circ} \mathrm{C}$, Fig. S.31) $\delta 210.30\left(\mathrm{dd}, J_{\mathrm{PC}}=85.0,60.4 \mathrm{~Hz}\right), 141.89\left(\mathrm{dd}, J_{\mathrm{PC}}=12.8,2.0 \mathrm{~Hz}\right), 138.67,134.90\left(\mathrm{~d}, J_{\mathrm{PC}}\right.$ $=2.6 \mathrm{~Hz}), 129.11,49.24\left(\mathrm{dd}, J_{\mathrm{PC}}=9.2,7.5 \mathrm{~Hz}\right), 38.56\left(\mathrm{dd}, J_{\mathrm{PC}}=15.6,10.5 \mathrm{~Hz}\right), 36.50$, 29.51, 21.23, 17.33 ppm. ${ }^{31} \mathrm{P}\left\{{ }^{1} \mathrm{H}\right\}$ NMR (162 MHz, chloroform- $d, 25{ }^{\circ} \mathrm{C}$, Fig. S.32) $\delta 270.71$ $\left(\mathrm{d},{ }^{2} J_{\mathrm{PP}}=29 \mathrm{~Hz}\right), 259.47\left(\mathrm{~d},{ }^{2} J_{\mathrm{PP}}=29 \mathrm{~Hz}\right) \mathrm{ppm}$.

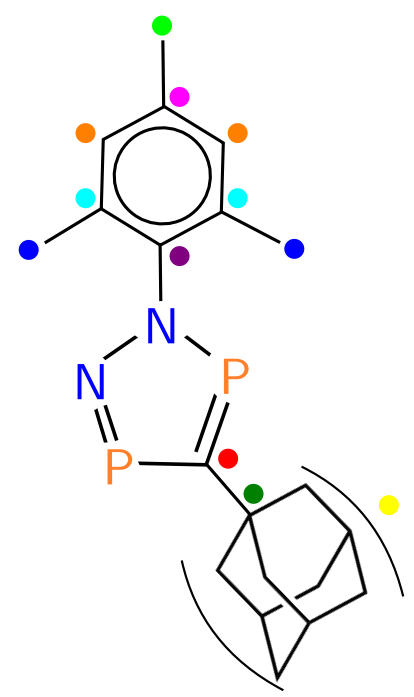

Figure S.29: Labeling scheme for 4. 


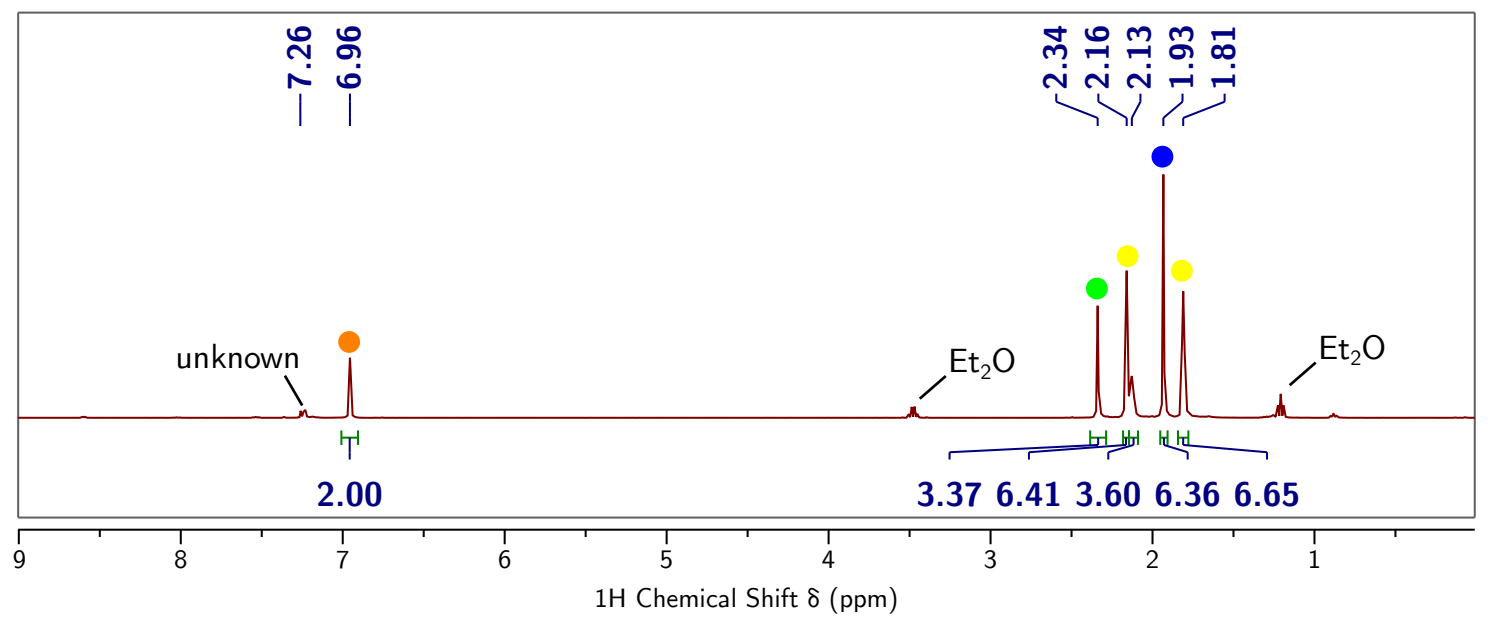

Figure S.30: ${ }^{1} \mathrm{H}$ NMR (400 MHz, chloroform- $d, 25{ }^{\circ} \mathrm{C}$ ) spectrum of 4 with residual diethyl ether.

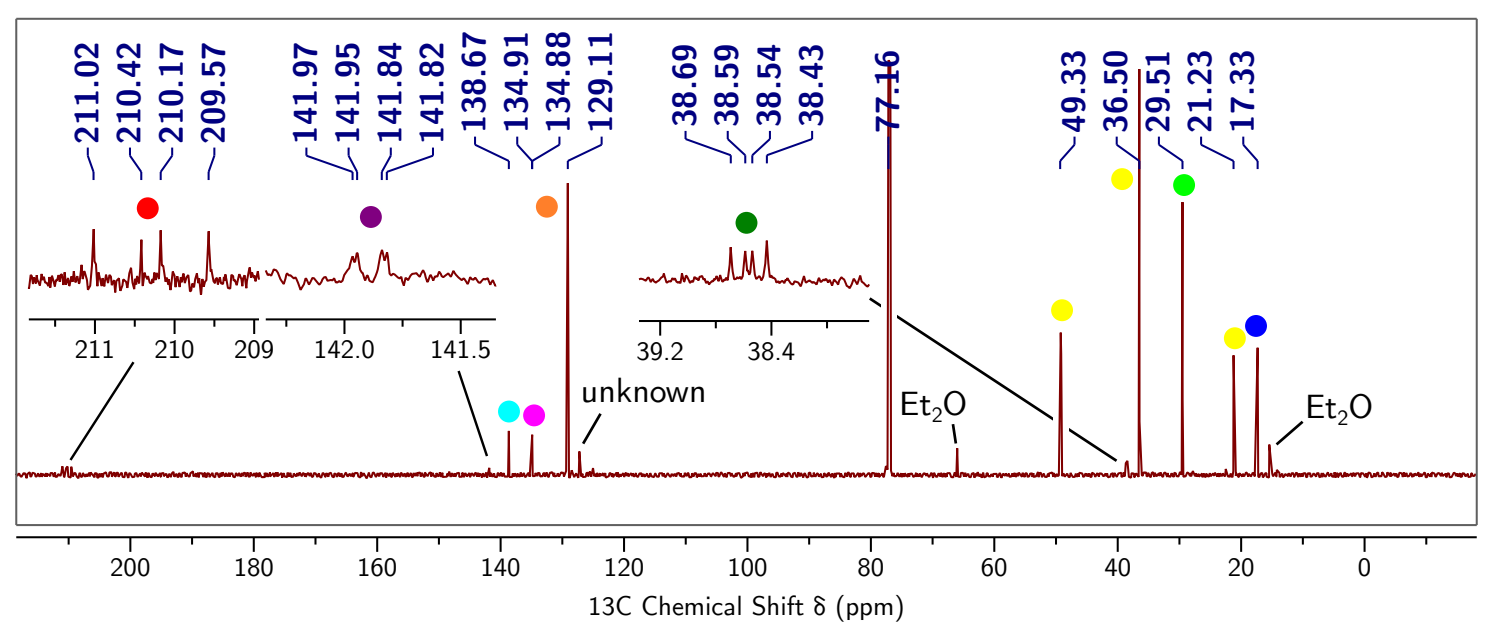

Figure S.31: ${ }^{13} \mathrm{C}\left\{{ }^{1} \mathrm{H}\right\}$ NMR (101 MHz, chloroform- $\left.d, 25{ }^{\circ} \mathrm{C}\right)$ spectrum of 4 with residual diethyl ether.

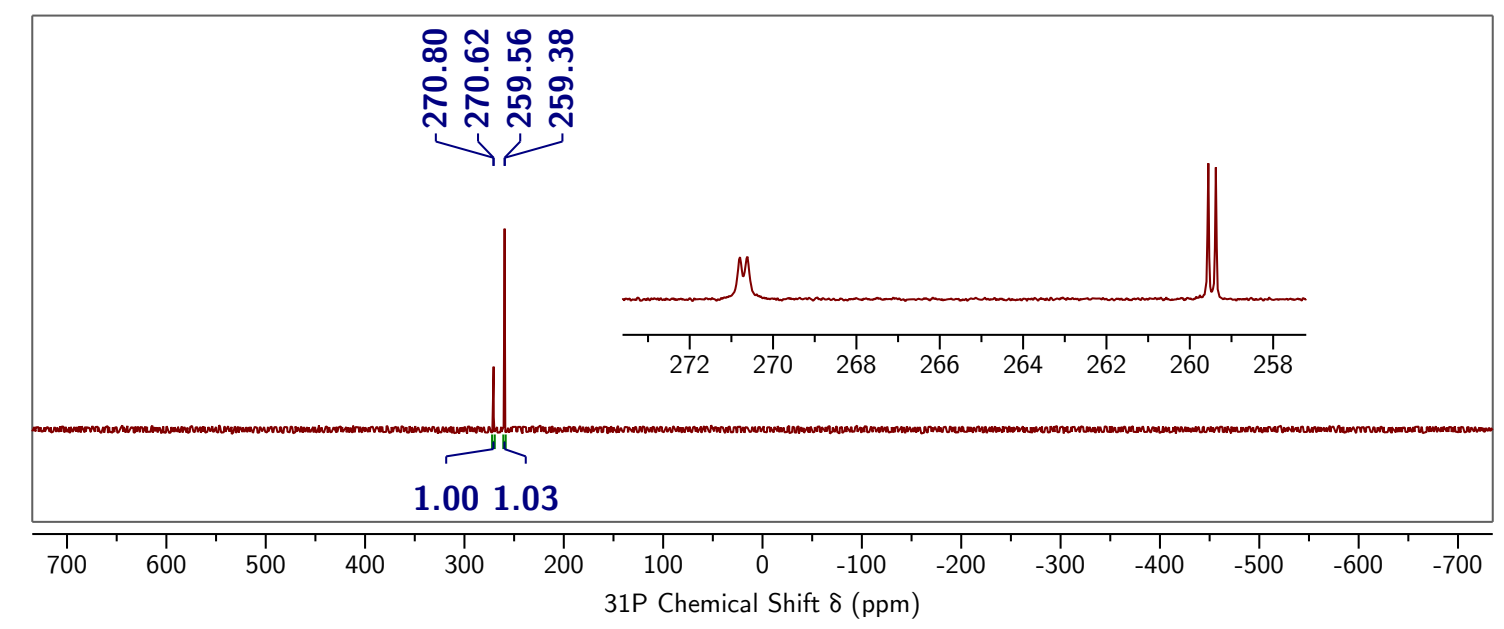

Figure S.32: ${ }^{31} \mathrm{P}\left\{{ }^{1} \mathrm{H}\right\}$ NMR $\left(162 \mathrm{MHz}\right.$, chloroform- $\left.d, 25{ }^{\circ} \mathrm{C}\right)$ spectrum of 4. 


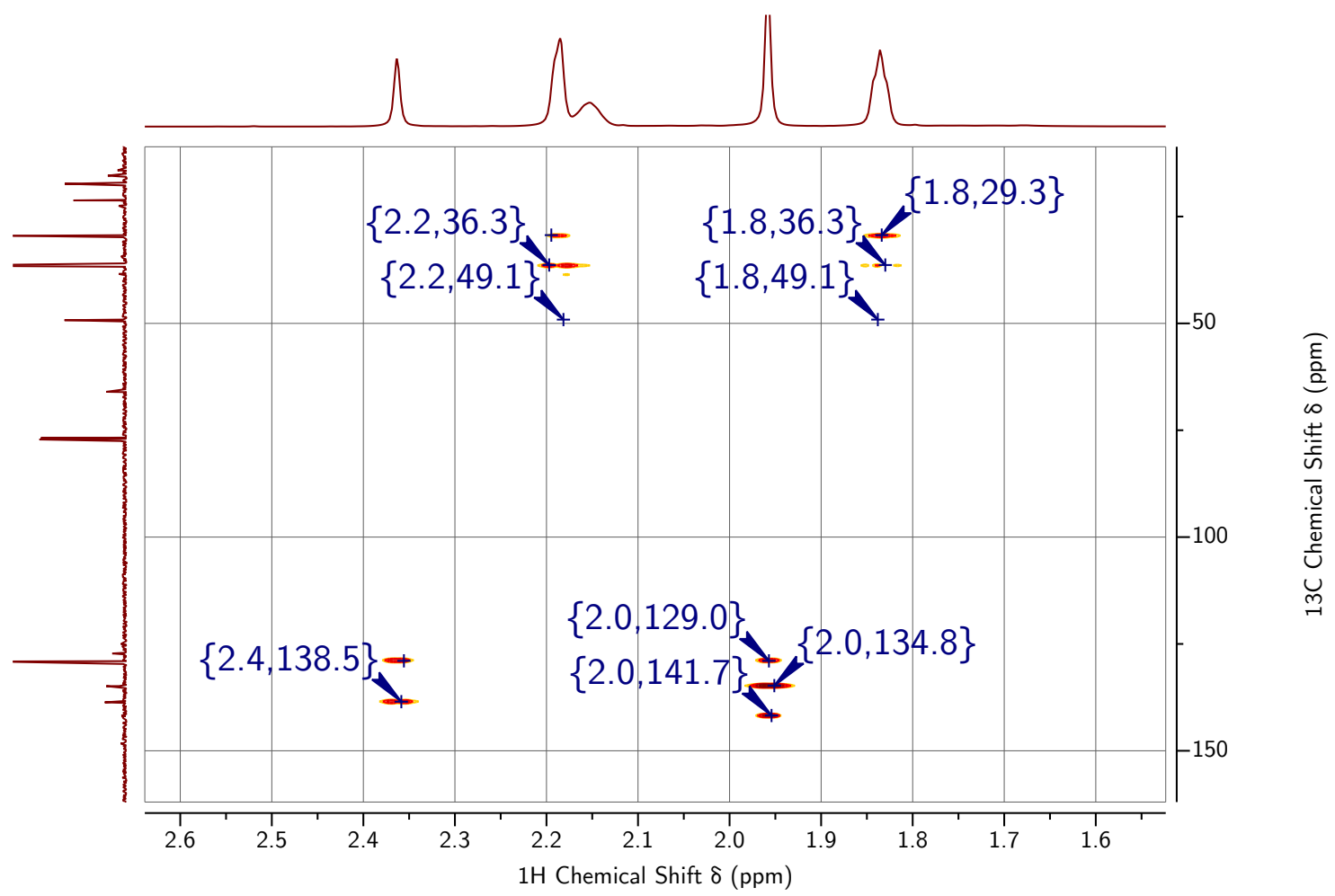

Figure S.33: ${ }^{1} \mathrm{H},{ }^{13} \mathrm{C}-\mathrm{HMBC}$ NMR $\left(400 \mathrm{MHz}\right.$, chloroform-d, $\left.25^{\circ} \mathrm{C}\right)$ spectrum of 4.

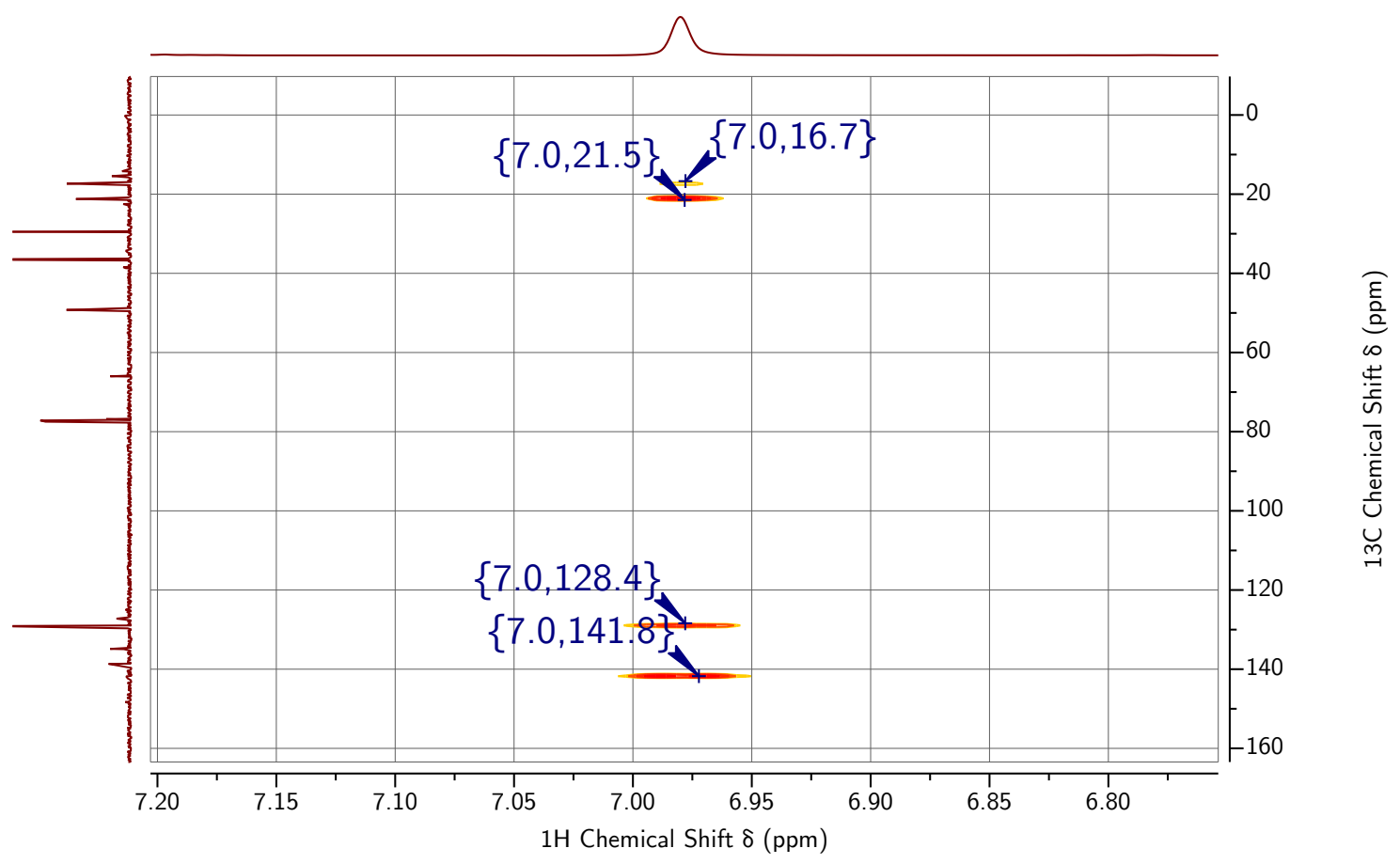

Figure S.34: ${ }^{1} \mathrm{H},{ }^{13} \mathrm{C}-\mathrm{HMBC}$ NMR $\left(400 \mathrm{MHz}\right.$, chloroform-d, $\left.25^{\circ} \mathrm{C}\right)$ spectrum of 4. 


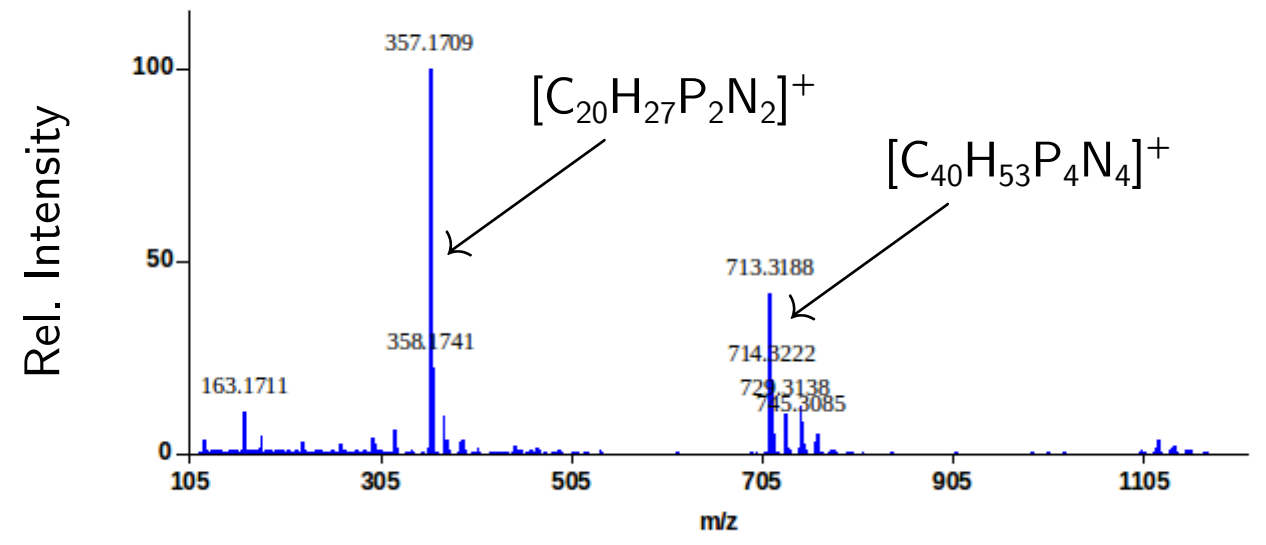

Isotope Match: $\left[\mathrm{C}_{20} \mathrm{H}_{27} \mathrm{P}_{2} \mathrm{~N}_{2}\right]^{+} \quad$ Isotope Match: $\left[\mathrm{C}_{40} \mathrm{H}_{53} \mathrm{P}_{4} \mathrm{~N}_{4}\right]^{+}$
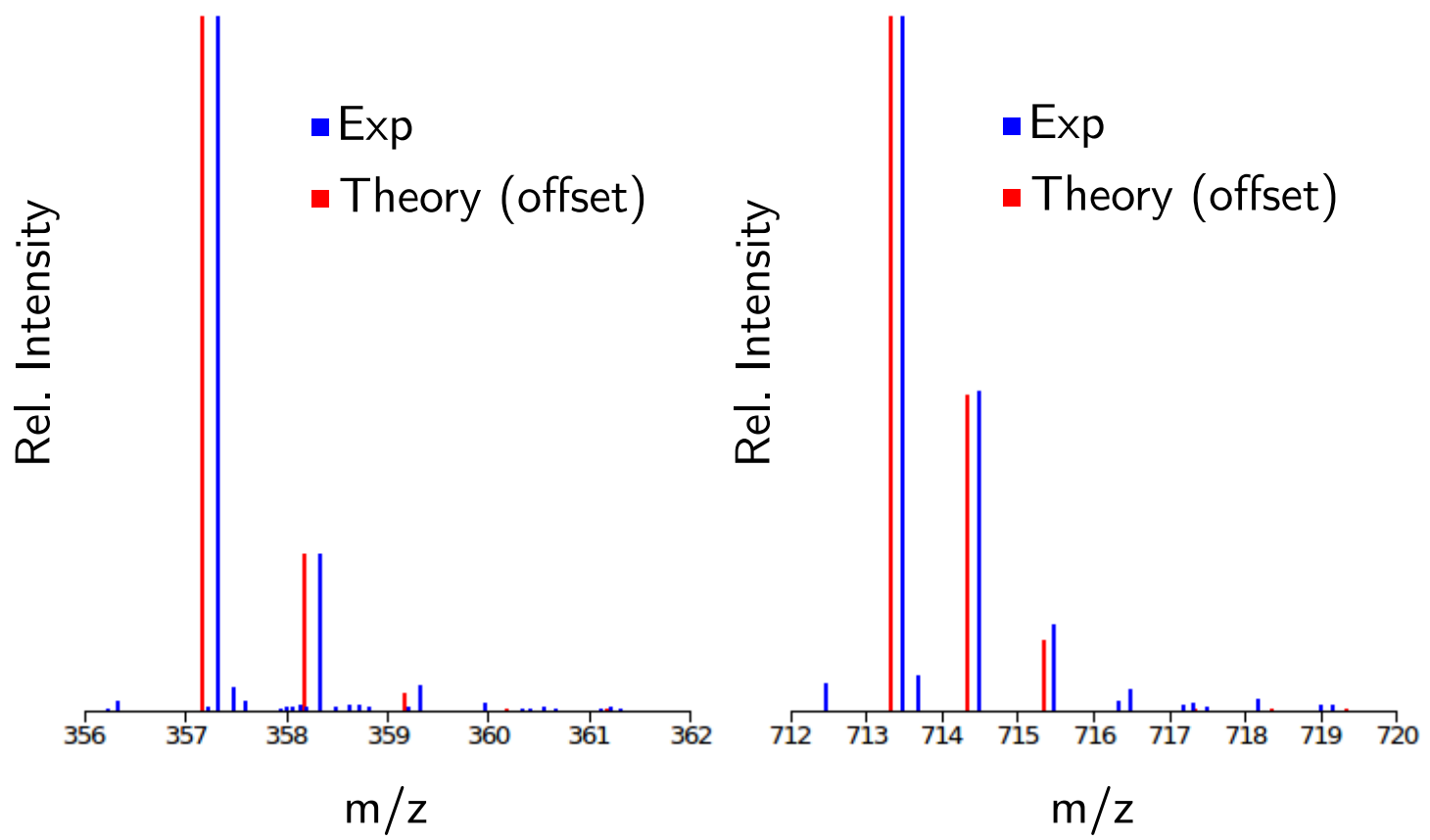

Figure S.35: DART HRMS(Q-TOF) data corresponding to $\left[\mathrm{C}_{20} \mathrm{H}_{27} \mathrm{P}_{2} \mathrm{~N}_{2}\right]^{+}$and $\left[\mathrm{C}_{40} \mathrm{H}_{53} \mathrm{P}_{4} \mathrm{~N}_{4}\right]^{+}$. 


\section{S.1.6 Generation of 5 from 1 and $\mathrm{P}_{2} \mathrm{~A}_{2}$}

Aluminum foil was used to limit exposure to ambient light during this experiment. A solution of 1 (67 mg, $0.19 \mathrm{mmol}, 1$ equiv) and $\mathrm{P}_{2} \mathbf{A}_{2}$ (79 mg, $0.19 \mathrm{mmol}, 1$ equiv) in THF (8 mL) was prepared. The solution stirred for $20 \mathrm{~h}$ at $23{ }^{\circ} \mathrm{C}$, during which the color of the solution faded from bright purple to pale orange. All volatile materials were removed from the orange solution under reduced pressure, resulting in a brown residue. The residue was taken up in pentane $(8 \mathrm{~mL})$ and filtered through a glass microfiber filter paper plugged pipette containing a one-inch plug of charcoal. The plug was washed with additional pentane $(2 \mathrm{~mL})$ and all volatile materials were removed from the combined filtrates in vacuo. The resulting colorless solids $(6 \mathrm{mg})$, were taken up in benzene- $d_{6}(0.7 \mathrm{~mL})$ for NMR analysis (Fig. S.36 and Fig. S.37). The colorless solids contain a mixture of compound 5, anthracene, and an unknown species. DART HRMS(Q-TOF) m/z: $[\mathrm{M}+\mathrm{H}]^{+}$Calcd for $\mathrm{C}_{9} \mathrm{H}_{12} \mathrm{~N}_{2} \mathrm{P}_{3} 241.0213$; Found 241.0241 (Fig. S.38). ${ }^{1} \mathrm{H}$ NMR (400 MHz, benzene- $d_{6}, 25{ }^{\circ} \mathrm{C}$, Fig. S.36) $\delta 6.63$ (s, 2H), $2.05(\mathrm{~s}, 6 \mathrm{H}), 1.65(\mathrm{~s}, 3 \mathrm{H}) \mathrm{ppm} .{ }^{31} \mathrm{P}\left\{{ }^{1} \mathrm{H}\right\} \mathrm{NMR}\left(162 \mathrm{MHz}\right.$, benzene- $d_{6}, 25{ }^{\circ} \mathrm{C}$, Fig. S.37) $\delta$ $404.42\left(\mathrm{~d},{ }^{1} J_{\mathrm{PP}}=511 \mathrm{~Hz}\right), 359.31\left(\mathrm{~d}, J_{\mathrm{PP}}=406 \mathrm{~Hz}\right), 329.84\left(\mathrm{dd},{ }^{1} J_{\mathrm{PP}}=512,406 \mathrm{~Hz}\right) \mathrm{ppm}$.

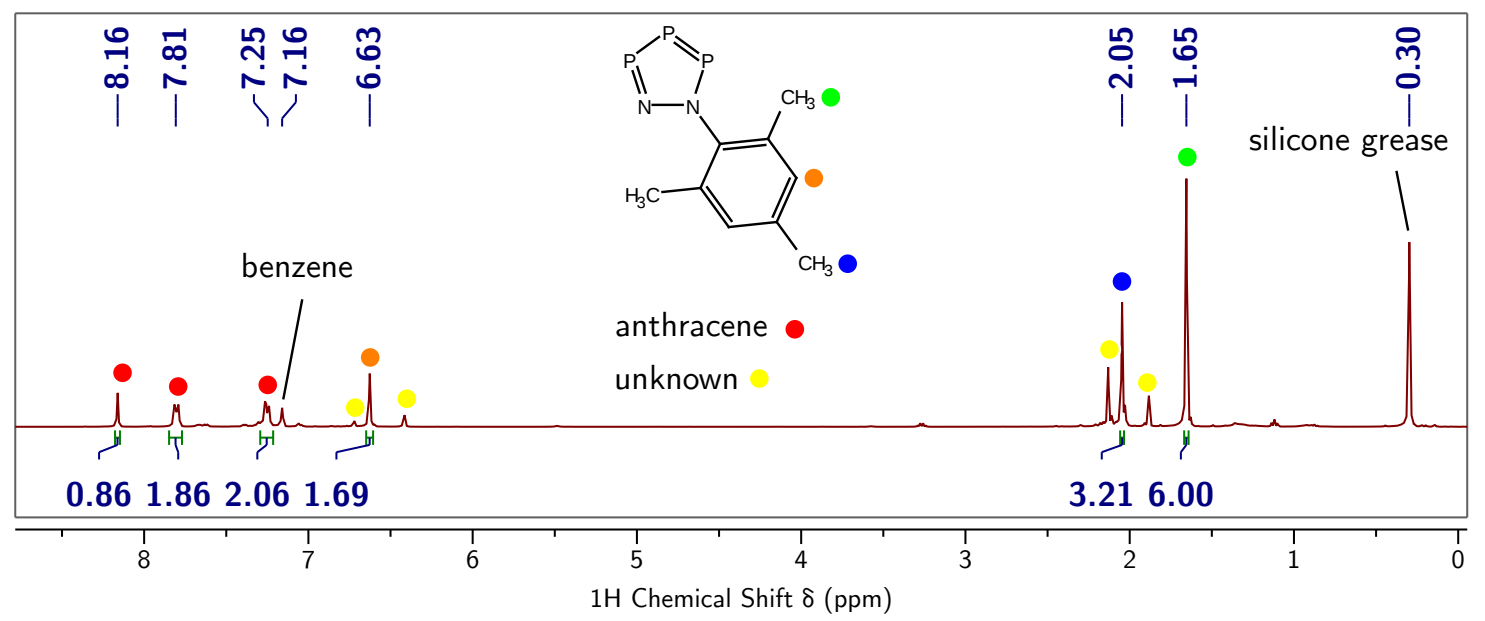

Figure S.36: ${ }^{1} \mathrm{H}$ NMR (400 MHz, benzene- $d_{6}, 25^{\circ} \mathrm{C}$ ) spectrum of 5 . 


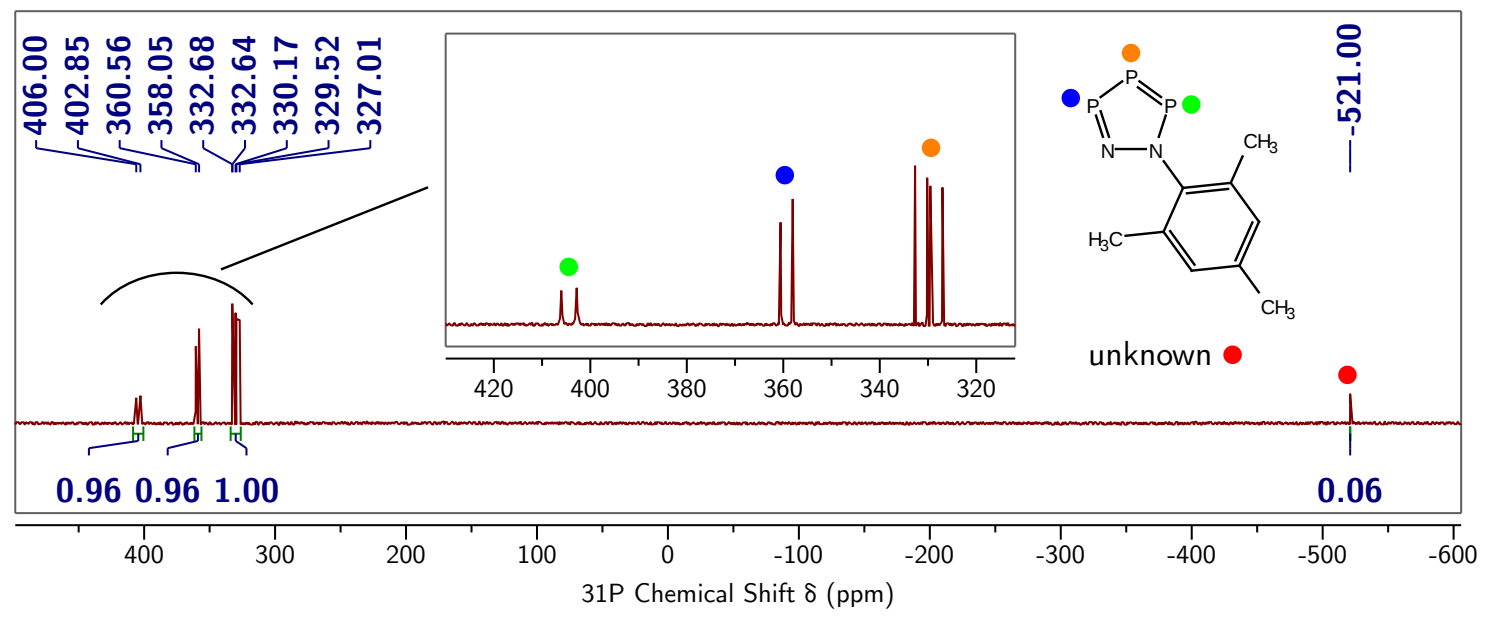

Figure S.37: ${ }^{31} \mathrm{P}$ NMR $\left(162 \mathrm{MHz}\right.$, benzene- $\left.d_{6}, 25{ }^{\circ} \mathrm{C}\right)$ spectrum of 5 . 


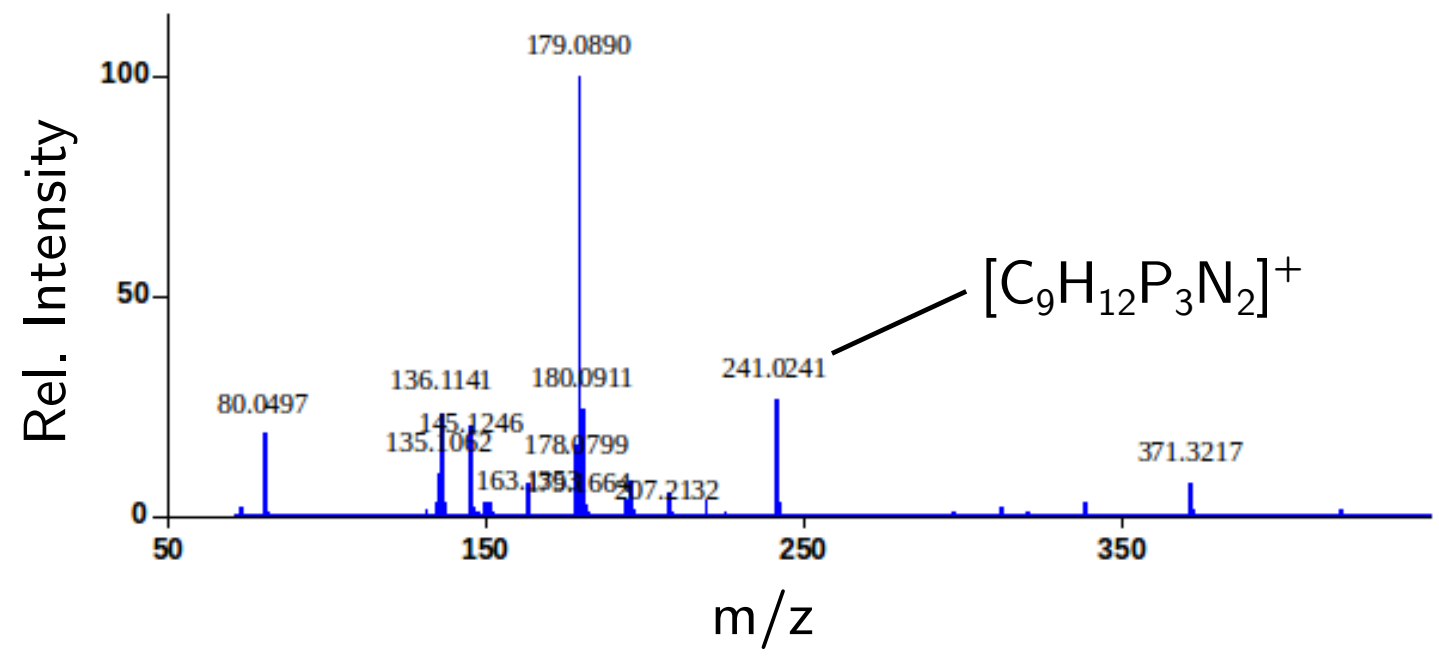

Isotope match: $\left[\mathrm{C}_{9} \mathrm{H}_{12} \mathrm{P}_{3} \mathrm{~N}_{2}\right]^{+}$

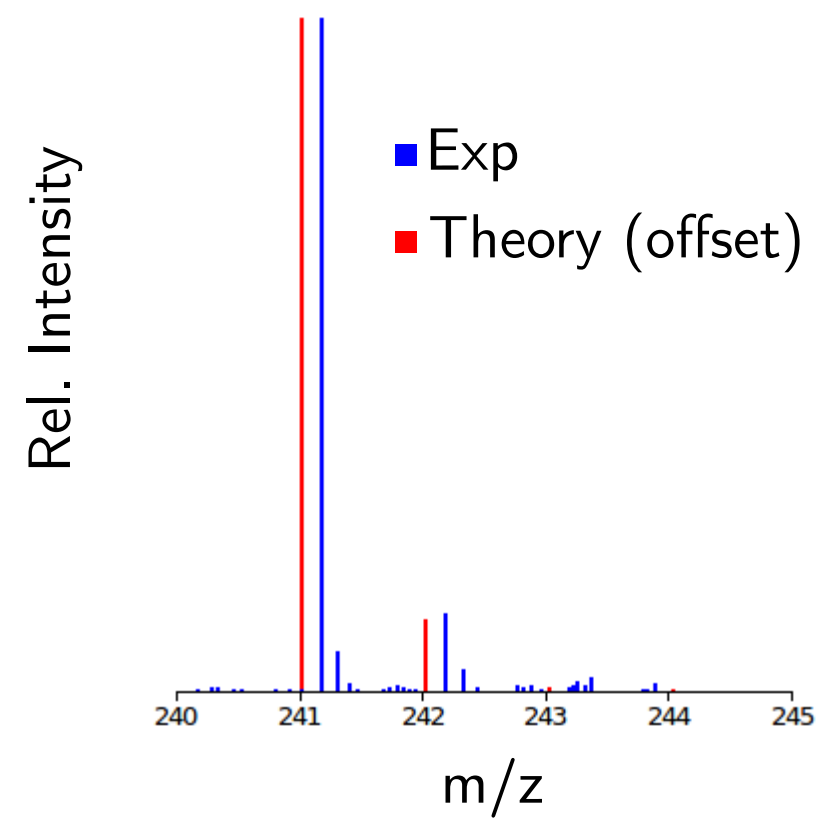

Figure S.38: DART HRMS(Q-TOF) data corresponding to $\left[\mathrm{C}_{9} \mathrm{H}_{12} \mathrm{P}_{3} \mathrm{~N}_{2}\right]^{+}$. 


\section{S.2 X-Ray Diffraction Studies}

Single crystals suitable for X-ray diffraction were transferred from the glovebox under Paratone oil onto a microscope slide. A crystal was selected under a microscope and mounted in hydrocarbon oil on a nylon loop. Low-temperature $(100 \mathrm{~K})$ diffraction data were collected on a Bruker-AXS X8 Kappa Duo diffractometer with $I \mu S$ micro-sources, coupled to a Photon 3 CPAD detector using Mo $K_{\alpha}$ radiation $(\lambda=0.71073 \AA)$ for the structure of $[3][\mathrm{Na}(12$ crown-4) $\left.)_{2}\right]$ and a smart APEX2 CCD detector using Mo $K_{\alpha}$ radiation $(\lambda=0.71073 \AA)$ for the structures of $\mathbf{1}$ and $\mathrm{P}_{2} \mathbf{A}_{2}$ performing $\phi$ - and $\omega$-scans. The structures were solved by dual-space methods using SHELXT ${ }^{11}$ and refined against $F^{2}$ on all data by full-matrix least squares with SHELXL-2017 ${ }^{11}$ following established refinement strategies. ${ }^{12}$ All non-hydrogen atoms were refined anisotropically. All hydrogen atoms were included into the model at geometrically calculated positions and refined using a riding model. The isotropic displacement parameters of all hydrogen atoms were fixed to 1.2 times the $U$-value of the atoms they are linked to (1.5 times for methyl groups). Details of the data quality and a summary of the residual values of the refinement are listed in tables S.2, S.3, and S.4. Further details can be found in the form of .cif files available from the CCDC.

Single crystals of 1 were grown from diethyl ether at $-35{ }^{\circ} \mathrm{C}$. The structure was solved in the tetragonal space group $P 4_{1}$ with two molecules of $\mathbf{1}$ and no solvent molecules in the asymmetric unit. The molecule exhibits no disorder. Single crystals of $[\mathbf{3}]\left[\mathrm{Na}(12 \text {-crown-4 })_{2}\right]$ were grown from acetonitrile at $-35^{\circ} \mathrm{C}$. The structure was solved in tetragonal space group $P 2_{1} / c$ with one molecule of $[\mathbf{3}]\left[\mathrm{Na}(12 \text {-crown-4) })_{2}\right]$ and no solvent molecules. 3 and one of the two 12-crown-4 molecules coordinated to a sodium ion were each refined over two positions. Disorders were refined with the help of the FLAT restraint in SHELXL and similarity restraints on 1,2 and 1,3 distances. Similarity and rigid bond restraints for anisotropic displacement parameters were applied to all non-hydrogen atoms. Single crystals of $\mathrm{P}_{2} \mathbf{A}_{2}$ were grown from tetrahydrofuran at $-35^{\circ} \mathrm{C}$. The structure was solved in the orthorhombic space group $P n a 2_{1}$ with one molecule of $\mathrm{P}_{2} \mathbf{A}_{2}$ and two molecules of tetrahydrofuran in the asymmetric 
unit. The molecule exhibits no disorder. 
Table S.2: Crystallographic Data for $\mathbf{1}$

\begin{tabular}{|c|c|}
\hline Reciprocal Net code / CCDC & X8_16085 / CCDC 1994977 \\
\hline Empirical formula, FW (g/mol) & $\mathrm{C}_{23} \mathrm{H}_{21} \mathrm{~N}_{2} \mathrm{P}, 356.39$ \\
\hline Color / Morphology & Red / Block \\
\hline Crystal size $\left(\mathrm{mm}^{3}\right)$ & $0.375 \times 0.356 \times 0.216$ \\
\hline Temperature (K) & $100(2)$ \\
\hline Wavelength $(\AA)$ & 0.71073 \\
\hline Crystal system, Space group & Tetragonal, $P 4_{1}$ \\
\hline Unit cell dimensions $\left(\AA,{ }^{\circ}\right)$ & $a=10.2348(5), \alpha=90$ \\
\hline & $b=10.2348(5), \beta=90$ \\
\hline & $c=35.3127(18), \gamma=90$ \\
\hline Volume $\left(\AA^{3}\right)$ & $3699.0(4)$ \\
\hline$Z$ & 8 \\
\hline Density (calc., g/ $\mathrm{cm}^{3}$ ) & 1.280 \\
\hline Absorption coefficient $\left(\mathrm{mm}^{-1}\right)$ & 0.157 \\
\hline$F(000)$ & 1504 \\
\hline Theta range for data collection $\left(^{\circ}\right)$ & 1.153 to 30.437 \\
\hline Index ranges & $\begin{array}{l}-14 \leq h \leq 13,-14 \leq k \leq 14 \\
-50 \leq l \leq 50\end{array}$ \\
\hline Reflections collected & 155472 \\
\hline Independent reflections, $R_{\text {int }}$ & $11233,0.0412$ \\
\hline Completeness to $\theta_{\max }(\%)$ & 100.0 \\
\hline Absorption correction & Semi-empirical from equivalents \\
\hline Refinement method & Full-matrix least-squares on $F^{2}$ \\
\hline Data / Restraints / Parameters & $11233 / 1 / 476$ \\
\hline Goodness-of-fit ${ }^{a}$ & 1.084 \\
\hline Final $R$ indices $^{b}[I>2 \sigma(I)]$ & $R_{1}=0.0286, w R_{2}=0.0782$ \\
\hline$R$ indices $^{b}$ (all data) & $R_{1}=0.0288, w R_{2}=0.0784$ \\
\hline Largest diff. peak and hole $\left(e \cdot \AA^{-3}\right)$ & 0.330 and -0.189 \\
\hline
\end{tabular}




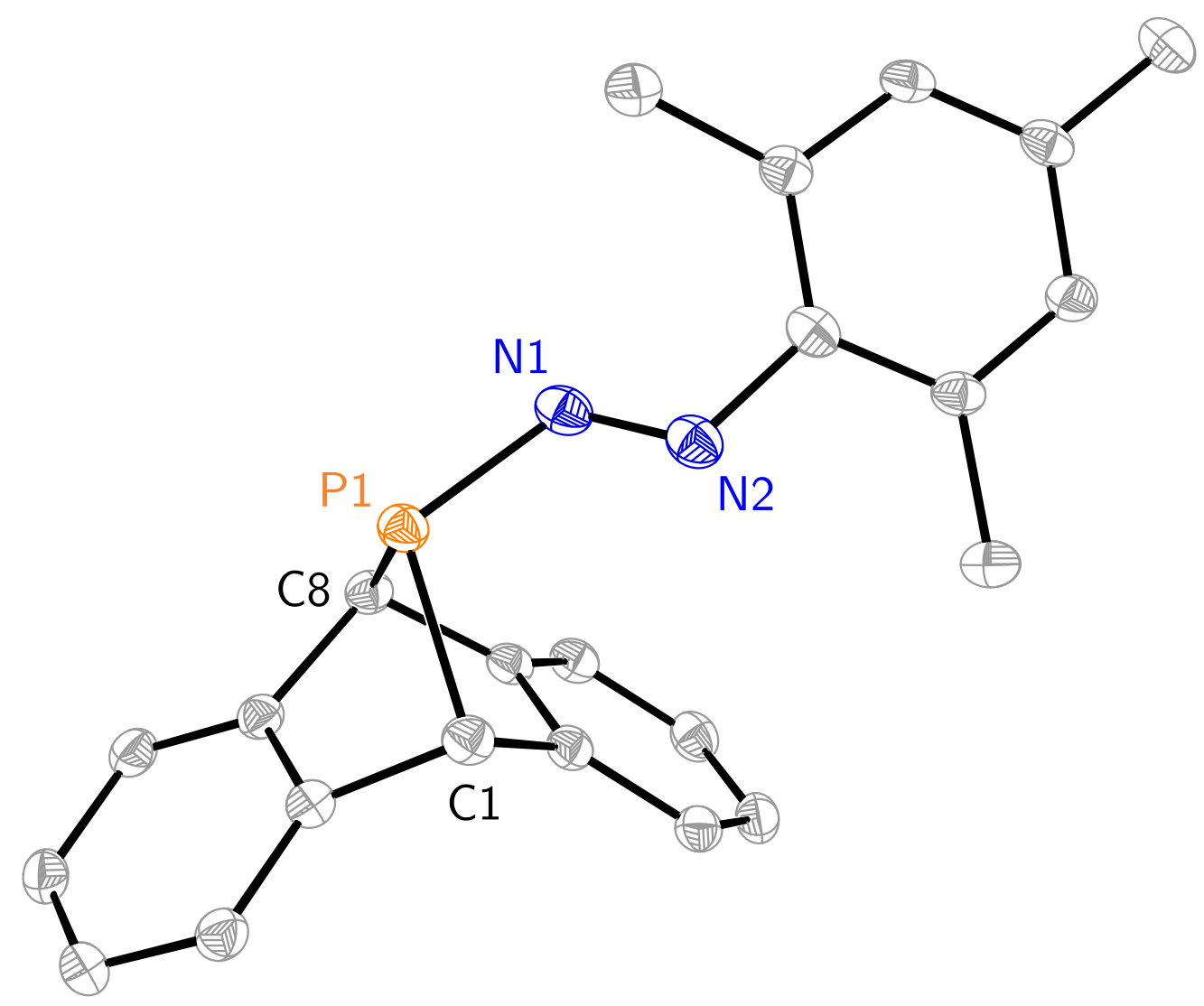

Figure S.39: Molecular structure of $\mathbf{1}$ with thermal ellipsoids shown at the $50 \%$ probability level. Hydrogen atoms are omitted for clarity. 
Table S.3: Crystallographic Data for $[3][\mathrm{Na}(12$-crown-4) 2$]$

\begin{tabular}{|c|c|}
\hline Reciprocal Net code / CCDC & P19081 / CCDC 1994975 \\
\hline Empirical formula, FW (g/mol) & $\mathrm{C}_{26} \mathrm{H}_{43} \mathrm{~N}_{2} \mathrm{P}_{2} \mathrm{NaO}_{9}, 610.32$ \\
\hline Color / Morphology & Colourless / Plate \\
\hline Crystal size $\left(\mathrm{mm}^{3}\right)$ & $0.928 \times 0.565 \times 0.100$ \\
\hline Temperature (K) & $100(2)$ \\
\hline Wavelength $(\AA)$ & 0.71073 \\
\hline Crystal system, Space group & Tetragonal, $P 2_{1} / c$ \\
\hline Unit cell dimensions $\left(\AA,^{\circ}\right)$ & $\begin{array}{l}a=13.5741(10), \alpha=90 \\
b=15.3701(11), \beta=110.869(2) \\
c=15.9864(11), \gamma=90\end{array}$ \\
\hline Volume $\left(\AA^{3}\right)$ & $3116.5(4)$ \\
\hline$Z$ & 4 \\
\hline Density (calc., g/cm³) & 1.301 \\
\hline Absorption coefficient $\left(\mathrm{mm}^{-1}\right)$ & 0.203 \\
\hline$F(000)$ & 1300 \\
\hline Theta range for data collection $\left(^{\circ}\right)$ & 1.606 to 31.506 \\
\hline Index ranges & $\begin{array}{l}-19 \leq h \leq 19,-22 \leq k \leq 22 \\
-23 \leq l \leq 23\end{array}$ \\
\hline Reflections collected & 127561 \\
\hline Independent reflections, $R_{\text {int }}$ & $10378,0.0441$ \\
\hline Completeness to $\theta_{\max }(\%)$ & 99.9 \\
\hline Absorption correction & None \\
\hline Refinement method & Full-matrix least-squares on $F^{2}$ \\
\hline Data / Restraints / Parameters & $10378 / 2386 / 554$ \\
\hline Goodness-of-fit ${ }^{a}$ & 1.160 \\
\hline Final $R$ indices $^{b}[I>2 \sigma(I)]$ & $R_{1}=0.0464, w R_{2}=0.1105$ \\
\hline$R$ indices $^{b}$ (all data) & $R_{1}=0.0569, w R_{2}=0.1149$ \\
\hline Largest diff. peak and hole $\left(e \cdot \AA^{-3}\right)$ & 0.537 and -0.350 \\
\hline
\end{tabular}




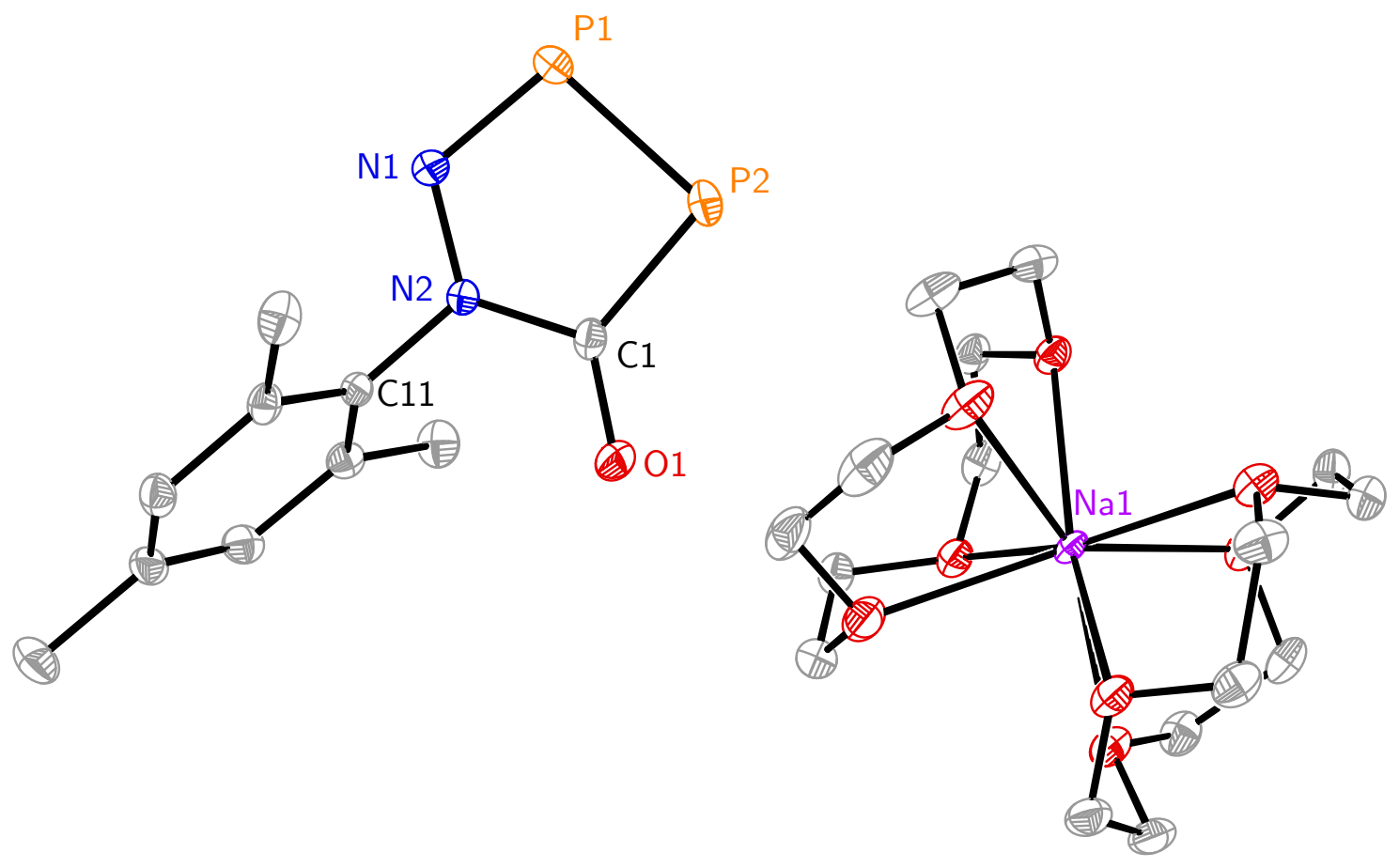

Figure S.40: Molecular structure of $[3][\mathrm{Na}(12$-crown-4) 2$]$ with thermal ellipsoids shown at the $50 \%$ probability level. Hydrogen atoms are omitted for clarity. 
Table S.4: Crystallographic Data for $\mathrm{P}_{2} \mathbf{A}_{2}$

\begin{tabular}{|c|c|}
\hline Reciprocal Net code / CCDC & X8_15149 / CCDC 1994976 \\
\hline Empirical formula, FW (g/mol) & $\mathrm{C}_{36} \mathrm{H}_{36} \mathrm{O}_{2} \mathrm{P}_{2}, 562.59$ \\
\hline Color / Morphology & Colourless / Block \\
\hline Crystal size $\left(\mathrm{mm}^{3}\right)$ & $0.410 \times 0.210 \times 0.150$ \\
\hline Temperature (K) & $100(2)$ \\
\hline Wavelength $(\AA)$ & 0.71073 \\
\hline Crystal system, Space group & Orthorhombic, Pna $2_{1}$ \\
\hline Unit cell dimensions $\left(\AA,^{\circ}\right)$ & $\begin{array}{l}a=28.734(2), \alpha=90 \\
b=8.0387(5), \beta=90 \\
c=12.4223(8), \gamma=90\end{array}$ \\
\hline Volume $\left(\AA^{3}\right)$ & $2869.3(3)$ \\
\hline & 4 \\
\hline Density (calc., $\mathrm{g} / \mathrm{cm}^{3}$ ) & 1.302 \\
\hline Absorption coefficient $\left(\mathrm{mm}^{-1}\right)$ & 0.184 \\
\hline$F(000)$ & 1192 \\
\hline Theta range for data collection $\left({ }^{\circ}\right)$ & 2.167 to 31.018 \\
\hline Index ranges & $\begin{array}{l}-33 \leq h \leq 41,-4 \leq k \leq 11 \\
-17 \leq l \leq 11\end{array}$ \\
\hline Reflections collected & 14119 \\
\hline Independent reflections, $R_{\text {int }}$ & $6904,0.0241$ \\
\hline Completeness to $\theta_{\max }(\%)$ & 98.4 \\
\hline Absorption correction & None \\
\hline Refinement method & Full-matrix least-squares on $F^{2}$ \\
\hline Data / Restraints / Parameters & $6904 / 61 / 362$ \\
\hline Goodness-of-fit ${ }^{a}$ & 1.054 \\
\hline Final $R$ indices $^{b}[I>2 \sigma(I)]$ & $R_{1}=0.0407, w R_{2}=0.1011$ \\
\hline$R$ indices $^{b}$ (all data) & $R_{1}=0.0457, w R_{2}=0.1051$ \\
\hline Largest diff. peak and hole $\left(e \cdot \AA^{-3}\right)$ & 0.695 and -0.380 \\
\hline
\end{tabular}




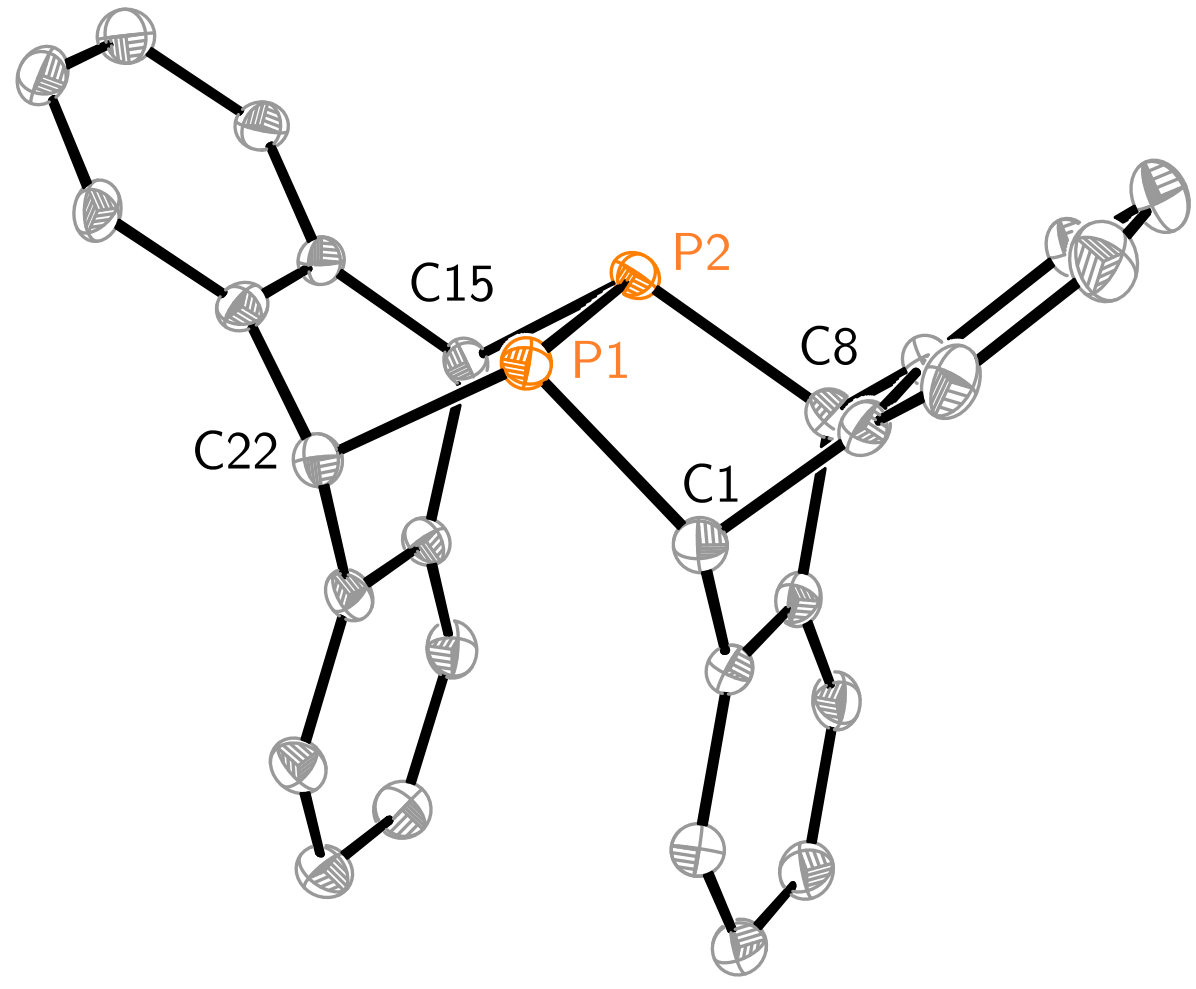

Figure S.41: Molecular structure of $\mathrm{P}_{2} \mathbf{A}_{2}$ with thermal ellipsoids shown at the $50 \%$ probability level. Hydrogen atoms and tetrahydrofuran are omitted for clarity. 


\section{S.3 Computational Studies}

\section{S.3.1 Molecular Orbital Analysis of 1}

Calculations were performed using ORCA 3.0.2. ${ }^{13}$ The initial geometry of $\mathbf{1}$ was taken from the crystal structure after optimizing the hydrogen positions at the Acc-Opt level of theory. The resulting geometry was optimized using keywords: PAL8 RIJK RI-PWPB95 D3BJ Def2-TZVPP def2-TZVPP/JK Def2-TZVPP/C TightSCF Grid5 FinalGrid6. The calculated HOMO and LUMO of $\mathbf{1}$ are depicted in Fig. S.42. The optimized coordinates of $\mathbf{1}$ are listed in S.3.1.1.

HOMO

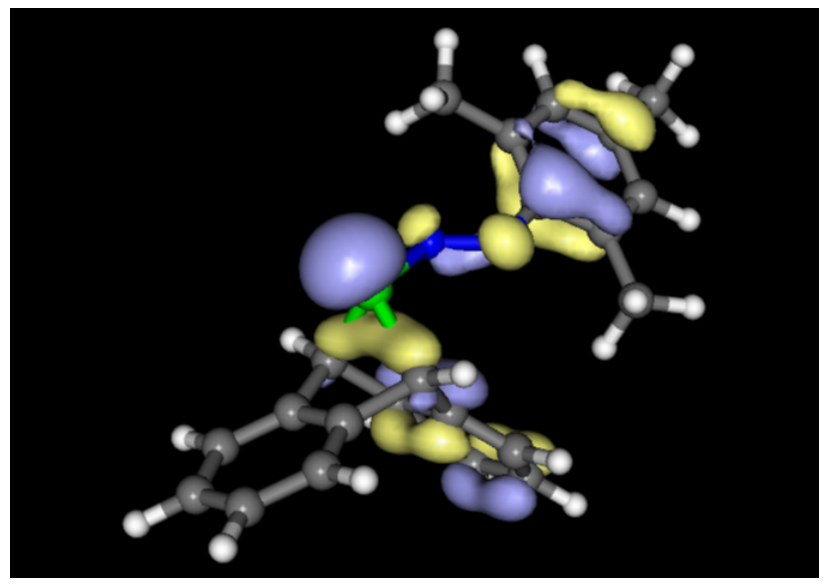

LUMO

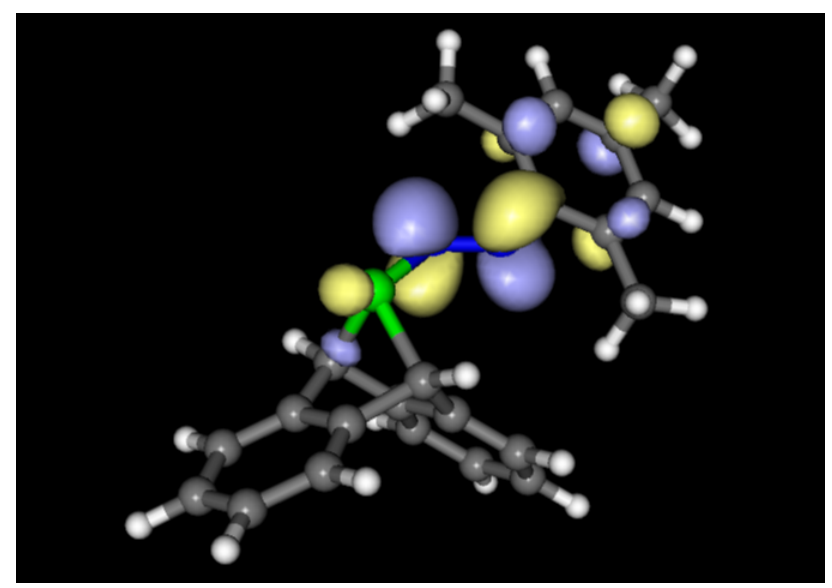

Figure S.42: Frontier molecular orbitals of 1. P (green), N (blue), C (gray), H (white). Graphics were generated using Molekel. ${ }^{14}$ 


\section{S.3.1.1 Coordinates (xyz) of 1}

\begin{tabular}{|c|c|c|c|}
\hline $\mathrm{P}$ & 1.220486 & -0.194622 & 1.432645 \\
\hline $\mathrm{N}$ & 0.999153 & 1.343106 & 2.229970 \\
\hline $\mathrm{N}$ & 1.972668 & 2.129088 & 2.321550 \\
\hline C & 0.000447 & -0.002751 & 0.004330 \\
\hline $\mathrm{H}$ & -1.065295 & -0.016428 & 0.250522 \\
\hline C & 0.519960 & 1.226879 & -0.701156 \\
\hline C & -0.187990 & 2.241164 & -1.322838 \\
\hline $\mathrm{H}$ & -1.279459 & 2.248737 & -1.319401 \\
\hline C & 0.528544 & 3.263225 & -1.964447 \\
\hline $\mathrm{H}$ & -0.018872 & 4.070278 & -2.455099 \\
\hline $\mathrm{C}$ & 1.904051 & 3.264978 & -1.977389 \\
\hline $\mathrm{H}$ & 2.446039 & 4.068638 & -2.478612 \\
\hline $\mathrm{C}$ & 2.628297 & 2.232485 & -1.338641 \\
\hline $\mathrm{H}$ & 3.719455 & 2.235804 & -1.347054 \\
\hline C & 1.922409 & 1.225790 & -0.705734 \\
\hline C & 2.451287 & -0.002448 & 0.003722 \\
\hline $\mathrm{H}$ & 3.517781 & -0.013919 & 0.243382 \\
\hline C & 1.927258 & -1.214299 & -0.758221 \\
\hline C & 2.628108 & -2.228134 & -1.388879 \\
\hline $\mathrm{H}$ & 3.719280 & -2.253673 & -1.367165 \\
\hline C & 1.908824 & -3.216128 & -2.058829 \\
\hline $\mathrm{H}$ & 2.443210 & -4.022205 & -2.564536 \\
\hline $\mathrm{C}$ & 0.514200 & -3.188984 & -2.100678 \\
\hline $\mathrm{H}$ & -0.023425 & -3.972103 & -2.637531 \\
\hline $\mathrm{C}$ & -0.201536 & -2.172083 & -1.456118 \\
\hline $\mathrm{H}$ & -1.292572 & -2.157063 & -1.477258 \\
\hline
\end{tabular}




\begin{tabular}{|c|c|c|c|}
\hline C & 0.514420 & -1.199319 & -0.785869 \\
\hline $\mathrm{C}$ & 1.685854 & 3.333180 & 3.067448 \\
\hline $\mathrm{C}$ & 2.292792 & 4.504653 & 2.597673 \\
\hline $\mathrm{C}$ & 2.015069 & 5.722713 & 3.233032 \\
\hline $\mathrm{H}$ & 2.464524 & 6.638778 & 2.842905 \\
\hline $\mathrm{C}$ & 1.197182 & 5.771501 & 4.359087 \\
\hline $\mathrm{C}$ & 0.660911 & 4.579547 & 4.846276 \\
\hline $\mathrm{H}$ & 0.046140 & 4.605421 & 5.750658 \\
\hline C & 0.872200 & 3.343885 & 4.224814 \\
\hline $\mathrm{C}$ & 3.213068 & 4.484659 & 1.402666 \\
\hline $\mathrm{H}$ & 3.936690 & 3.661187 & 1.473702 \\
\hline $\mathrm{H}$ & 3.758344 & 5.434848 & 1.324550 \\
\hline $\mathrm{H}$ & 2.656828 & 4.329773 & 0.467049 \\
\hline $\mathrm{C}$ & 0.933085 & 7.075431 & 5.061644 \\
\hline $\mathrm{H}$ & 1.544549 & 7.166636 & 5.974079 \\
\hline $\mathrm{H}$ & -0.118808 & 7.161421 & 5.371095 \\
\hline $\mathrm{H}$ & 1.171145 & 7.933802 & 4.419116 \\
\hline C & 0.244933 & 2.122589 & 4.836852 \\
\hline $\mathrm{H}$ & -0.000857 & 2.320793 & 5.890079 \\
\hline $\mathrm{H}$ & 0.905771 & 1.246424 & 4.79467 \\
\hline $\mathrm{H}$ & -0.679035 & 1.835735 & 4.316 \\
\hline
\end{tabular}




\section{S.3.2 Mechanism for 1 Fragmentation}

All calculations were performed using the ORCA 4.2.0 quantum chemistry package. ${ }^{13,15}$ Geometry optimizations and frequency calculations were performed at the B3LYP-D3/def2TZVP(-f) level of theory using keywords B3LYP D3BJ def2-TZVP(-f) def2/J TightSCF RIJCOSX Opt AnFreq. The transition state geometry was determined using the zoom Nudged Elastic Band (zNEB) method, which was implemented using keyword Z0OM-NEB-TS. Intermediate and transition state geometries were found to have zero and one imaginary frequency, respectively. The coordinates of the optimized geometries are listed in S.3.2.1S.3.2.4. Electronic energies of the DFT-optimized geometries were calculated using the domain-based local pair natural orbital coupled-cluster method with singles, doubles, and perturbative triples excitation (DLPNO-CCSD $(\mathrm{T}))^{16}$ with the cc-pVTZ basis set ${ }^{17}$ using keywords cc-pVTZ cc-pVTZ/C DLPNO-CCSD(T1) TightSCF TightPNO. DFT-calculated corrections for zero-point energy, thermal energy, and entropic effects were combined with the computed DLPNO-CCSD(T) electronic energies to obtain enthalpy, entropy, and free energy (reported at $298.15 \mathrm{~K}) .{ }^{18,19}$ The results are summarized in Fig. S.43.

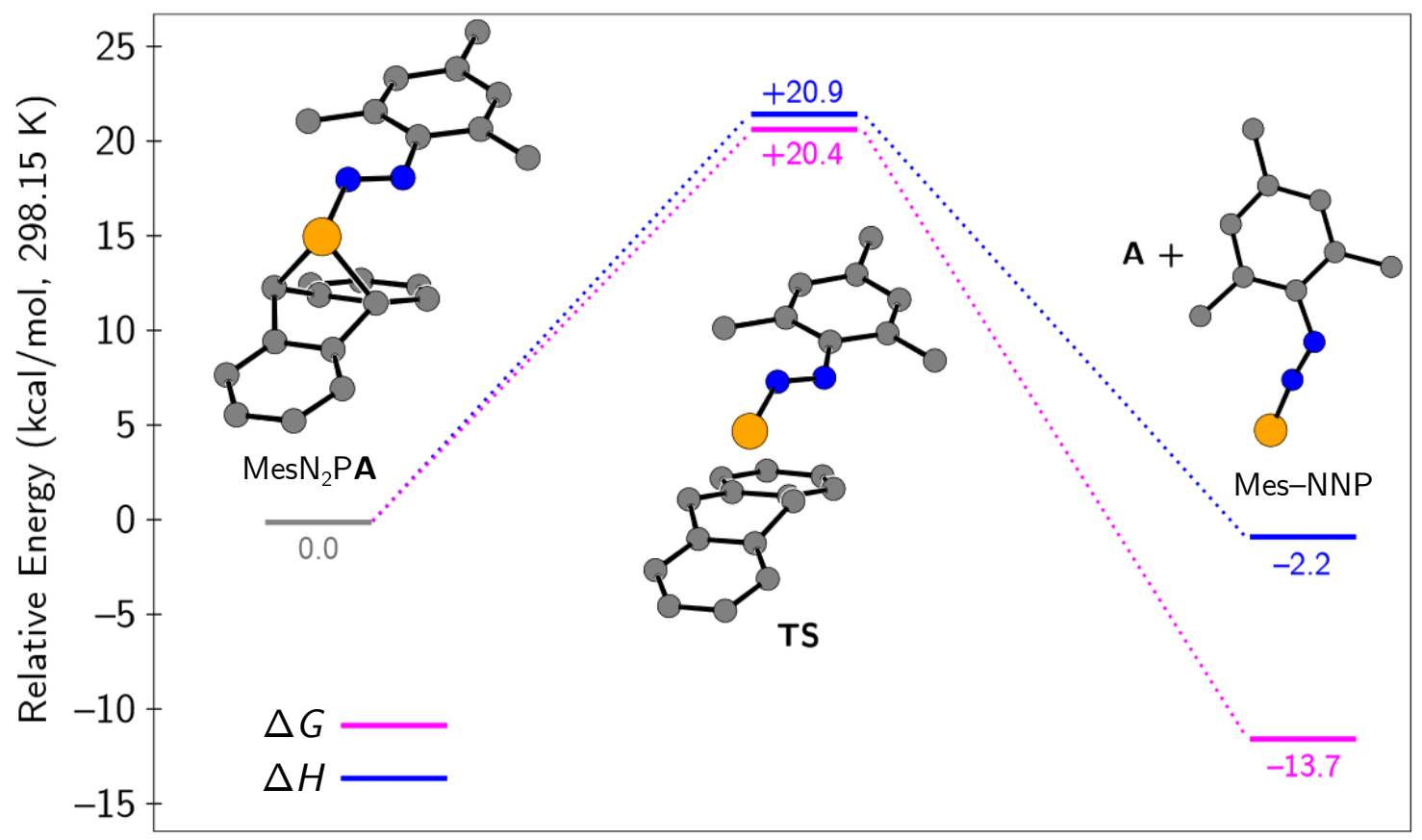

Figure S.43: Calculated minimum energy pathway for $\mathrm{MesN}_{2} \mathrm{PA}$ fragmentation. 


\section{S.3.2.1 Coordinates (xyz) of 1}

$\begin{array}{lrrr}\text { P } & -0.283233 & -1.380391 & -2.097021 \\ \text { N } & -0.234385 & -1.630555 & -0.401298 \\ \text { N } & 0.765931 & -1.255267 & 0.260421 \\ \text { C } & 0.617009 & -1.247759 & 1.662632 \\ \text { C } & -0.641927 & -1.293831 & 2.305969 \\ \text { C } & -0.680891 & -1.109266 & 3.683748 \\ \text { C } & 0.460866 & -0.886637 & 4.442370 \\ \text { C } & 1.688390 & -0.833761 & 3.785542 \\ \text { C } & 1.791450 & -0.995355 & 2.409039 \\ \text { C } & -1.949954 & -1.460400 & 1.587148 \\ \text { H } & -2.034591 & -2.439082 & 1.117738 \\ \text { H } & -2.036751 & -0.737895 & 0.776657 \\ \text { H } & -2.772842 & -1.313333 & 2.286312 \\ \text { H } & -1.648145 & -1.124236 & 4.171437 \\ \text { C } & 0.370466 & -0.704508 & 5.931980 \\ \text { H } & -0.642257 & -0.436237 & 6.235760 \\ \text { H } & 1.050134 & 0.073508 & 6.281939 \\ \text { H } & 0.642256 & -1.627775 & 6.452520 \\ \text { H } & 2.585578 & -0.633662 & 4.360559 \\ \text { C } & 3.143427 & -0.870079 & 1.756384 \\ \text { H } & 3.135427 & -0.114967 & 0.970535 \\ \text { H } & 3.460499 & -1.805087 & 1.290370 \\ \text { H } & 3.891682 & -0.589235 & 2.499635 \\ \text { C } & 0.824876 & 0.166630 & -2.380776 \\ \text { C } & 0.243622 & 0.450115 & -3.743335 \\ & 0.909158 & 0.488054 & -4.956876\end{array}$




\begin{tabular}{|c|c|c|c|}
\hline C & 0.166210 & 0.532863 & -6.134392 \\
\hline C & -1.224638 & 0.557878 & -6.091262 \\
\hline C & -1.899547 & 0.503514 & -4.871471 \\
\hline $\mathrm{C}$ & -1.161387 & 0.426104 & -3.697607 \\
\hline $\mathrm{C}$ & -1.625594 & 0.090924 & -2.296604 \\
\hline $\mathrm{C}$ & -1.106358 & 1.076243 & -1.284874 \\
\hline $\mathrm{C}$ & -1.798988 & 1.718160 & -0.269540 \\
\hline $\mathrm{C}$ & -1.079396 & 2.346070 & 0.751853 \\
\hline $\mathrm{C}$ & 0.309008 & 2.345516 & 0.736685 \\
\hline $\mathrm{C}$ & 1.004116 & 1.739639 & -0.312729 \\
\hline $\mathrm{C}$ & 0.297357 & 1.106249 & -1.318190 \\
\hline $\mathrm{H}$ & 1.894326 & -0.010445 & -2.358437 \\
\hline $\mathrm{H}$ & 1.990031 & 0.427009 & -4.986385 \\
\hline $\mathrm{H}$ & 0.676777 & 0.520108 & -7.088710 \\
\hline $\mathrm{H}$ & -1.787962 & 0.582584 & -7.015661 \\
\hline $\mathrm{H}$ & -2.982862 & 0.485776 & -4.851154 \\
\hline $\mathrm{H}$ & -2.678376 & -0.164694 & -2.210782 \\
\hline $\mathrm{H}$ & -2.882181 & 1.694358 & -0.230281 \\
\hline $\mathrm{H}$ & -1.607888 & 2.801234 & 1.580456 \\
\hline $\mathrm{H}$ & 0.857558 & 2.774597 & 1.565066 \\
\hline $\mathrm{H}$ & 2.085219 & 1.691380 & -0.293132 \\
\hline
\end{tabular}

\section{S.3.2.2 Coordinates (xyz) of TS}

$\begin{array}{llll}\mathrm{P} & -0.171540 & -1.577743 & -2.059817 \\ \mathrm{~N} & 0.076217 & -1.791126 & -0.489404 \\ \mathrm{~N} & 0.931566 & -1.325569 & 0.317832 \\ \mathrm{C} & 0.665125 & -1.231959 & 1.675236\end{array}$




\begin{tabular}{|c|c|c|c|}
\hline C & -0.612092 & -1.277286 & 2.288390 \\
\hline C & -0.680886 & -1.103177 & 3.666757 \\
\hline C & 0.445583 & -0.880818 & 4.454541 \\
\hline C & 1.687696 & -0.812844 & 3.824524 \\
\hline C & 1.818767 & -0.968430 & 2.456334 \\
\hline C & -1.887006 & -1.459203 & 1.517305 \\
\hline $\mathrm{H}$ & -1.935305 & -2.433601 & 1.029874 \\
\hline $\mathrm{H}$ & -1.974448 & -0.714330 & 0.726302 \\
\hline $\mathrm{H}$ & -2.739958 & -1.354342 & 2.189247 \\
\hline $\mathrm{H}$ & -1.655979 & -1.132328 & 4.140518 \\
\hline C & 0.341137 & -0.713239 & 5.944556 \\
\hline $\mathrm{H}$ & -0.672413 & -0.449963 & 6.248477 \\
\hline $\mathrm{H}$ & 1.018498 & 0.064234 & 6.301606 \\
\hline $\mathrm{H}$ & 0.617411 & -1.638062 & 6.460757 \\
\hline $\mathrm{H}$ & 2.573666 & -0.620655 & 4.419263 \\
\hline C & 3.171420 & -0.860633 & 1.808730 \\
\hline $\mathrm{H}$ & 3.170191 & -0.105821 & 1.022337 \\
\hline $\mathrm{H}$ & 3.462610 & -1.798379 & 1.331293 \\
\hline $\mathrm{H}$ & 3.925618 & -0.596022 & 2.550083 \\
\hline $\mathrm{C}$ & 0.778970 & 0.208069 & -2.387657 \\
\hline C & 0.192207 & 0.443316 & -3.722155 \\
\hline C & 0.875719 & 0.407642 & -4.934771 \\
\hline C & 0.168822 & 0.460283 & -6.126771 \\
\hline C & -1.230054 & 0.508850 & -6.118787 \\
\hline C & -1.924533 & 0.520259 & -4.923590 \\
\hline C & -1.224178 & 0.510775 & -3.706620 \\
\hline C & -1.838559 & 0.489533 & -2.406456 \\
\hline
\end{tabular}




$\begin{array}{lrrr}\mathrm{C} & -1.177753 & 1.132229 & -1.306869 \\ \mathrm{C} & -1.832906 & 1.739114 & -0.225176 \\ \mathrm{C} & -1.094256 & 2.297970 & 0.804077 \\ \mathrm{C} & 0.301837 & 2.264270 & 0.775551 \\ \mathrm{C} & 0.964935 & 1.645091 & -0.276749 \\ \mathrm{C} & 0.241454 & 1.066370 & -1.313073 \\ \mathrm{H} & 1.856887 & 0.060448 & -2.367239 \\ \mathrm{H} & 1.956833 & 0.333852 & -4.940871 \\ \mathrm{H} & 0.702048 & 0.448737 & -7.068515 \\ \mathrm{H} & -1.771243 & 0.534152 & -7.055699 \\ \mathrm{H} & -3.007517 & 0.552635 & -4.917407 \\ \mathrm{H} & -2.910426 & 0.334779 & -2.348037 \\ \mathrm{H} & -2.915452 & 1.777498 & -0.206150 \\ \mathrm{H} & -1.602536 & 2.768293 & 1.636005 \\ \mathrm{H} & 0.868422 & 2.697542 & 1.588992 \\ \mathrm{H} & 2.045398 & 1.579587 & -0.276773\end{array}$

S.3.2.3 Coordinates (xyz) of Anthracene

$\begin{array}{lrrr}\text { C } & 0.000017 & 3.644415 & 0.710719 \\ \text { C } & 0.000018 & -3.644415 & -0.710719 \\ \text { C } & 0.000017 & 3.644414 & -0.710718 \\ \text { C } & 0.000018 & -3.644415 & 0.710718 \\ \text { C } & -0.000006 & 2.469079 & 1.402064 \\ \text { C } & -0.000006 & -2.469079 & -1.402064 \\ \text { C } & -0.000004 & 2.469079 & -1.402064 \\ \text { C } & -0.000003 & -2.469079 & 1.402065 \\ \text { C } & -0.000031 & 0.000002 & 1.398789\end{array}$




$\begin{array}{lrrr}\text { C } & -0.000031 & -0.000002 & -1.398789 \\ \text { C } & -0.000022 & 1.218191 & 0.719798 \\ \text { C } & -0.000021 & -1.218192 & -0.719798 \\ \text { C } & -0.000021 & 1.218189 & -0.719802 \\ \text { C } & -0.000020 & -1.218189 & 0.719803 \\ \text { H } & 0.000033 & 4.587249 & 1.242511 \\ \text { H } & 0.000033 & -4.587249 & -1.242512 \\ \text { H } & 0.000039 & 4.587249 & -1.242510 \\ \text { H } & 0.000038 & -4.587250 & 1.242509 \\ \text { H } & -0.000000 & 2.467426 & 2.485873 \\ \text { H } & -0.000002 & -2.467425 & -2.485873 \\ \text { H } & 0.000004 & 2.467431 & -2.485873 \\ \text { H } & 0.000003 & -2.467432 & 2.485874 \\ \text { H } & -0.000026 & 0.000005 & 2.483553 \\ \text { H } & -0.000026 & -0.000004 & -2.483553\end{array}$

S.3.2.4 Coordinates (xyz) of $\operatorname{MesN}_{2} \mathrm{P}$

$\begin{array}{llll}\mathrm{P} & 0.240783 & 0.293916 & 0.072721 \\ \mathrm{~N} & 0.051927 & 0.114340 & 1.581198 \\ \mathrm{~N} & 0.025230 & 0.022432 & 2.799319 \\ \mathrm{C} & -1.148317 & -0.165931 & 3.560164 \\ \mathrm{C} & -2.256006 & -0.914945 & 3.125595 \\ \mathrm{C} & -2.287125 & -1.637114 & 1.805238 \\ \mathrm{H} & -2.455638 & -0.956690 & 0.969069 \\ \mathrm{H} & -1.350750 & -2.160731 & 1.610940 \\ \mathrm{H} & -3.091043 & -2.373311 & 1.804985 \\ \mathrm{C} & -3.343804 & -1.031173 & 3.988344\end{array}$




$\begin{array}{llll}\mathrm{H} & -4.198129 & -1.612659 & 3.660491 \\ \mathrm{C} & -3.367466 & -0.449142 & 5.249372 \\ \mathrm{C} & -4.554232 & -0.608878 & 6.160410 \\ \mathrm{H} & -4.893022 & 0.355421 & 6.546056 \\ \mathrm{H} & -4.305595 & -1.231333 & 7.024142 \\ \mathrm{H} & -5.390598 & -1.078794 & 5.642393 \\ \mathrm{C} & -2.240795 & 0.262438 & 5.659140 \\ \mathrm{H} & -2.230884 & 0.722264 & 6.641018 \\ \mathrm{C} & -1.126857 & 0.407627 & 4.845638 \\ \mathrm{C} & 0.077637 & 1.173908 & 5.318911 \\ \mathrm{H} & 0.951456 & 0.522604 & 5.391168 \\ \mathrm{H} & 0.338817 & 1.973675 & 4.624981 \\ \mathrm{H} & -0.108591 & 1.614208 & 6.298662\end{array}$

\section{S.3.3 Calculated Lowest Energy Pathway for the Reaction of 1 and Cyclooctyne to Give 2}

All calculations were performed using the ORCA 4.2.0 quantum chemistry package. ${ }^{13,15}$ Initial geometries were constructed in Avogadro. ${ }^{20}$ Geometry optimizations and frequency calculations were performed at the $\omega$ B97X-D3/Def2-TZVP level of theory using keywords wB97X-D3 def2-TZVP def2/J TightSCF RIJCOSX Grid4 FinalGrid5 Opt NumFreq. For transition states, keyword Opt was replaced by OptTS. Intermediate and transition state geometries were found to have zero and one imaginary frequency, respectively. The coordinates of the optimized geometries are listed in S.3.3.1-S.3.3.7.

\section{S.3.3.1 Coordinates (xyz) of 1}

$$
\begin{array}{lrrr}
\mathrm{P} & -3.33495434019819 & 7.92804456216414 & 17.72530966403236 \\
\mathrm{~N} & -1.79153740558181 & 7.87940510343357 & 16.93241483878029
\end{array}
$$




\begin{tabular}{|c|c|c|c|}
\hline $\mathrm{N}$ & -0.93416960825105 & 8.68441519450841 & 17.31708512051081 \\
\hline C & -3.49967120158517 & 6.12242216517441 & 18.22859538700521 \\
\hline $\mathrm{H}$ & -3.70815202955572 & 5.40549180442408 & 17.44023951177404 \\
\hline C & -2.23848094547603 & 5.89097790914481 & 19.03316904396244 \\
\hline C & -1.40107149442040 & 4.79807543790409 & 19.05580671156436 \\
\hline $\mathrm{H}$ & -1.60013312477019 & 3.93288947217474 & 18.43503850847448 \\
\hline $\mathrm{C}$ & -0.28019447846337 & 4.82719195964773 & 19.88688493558230 \\
\hline $\mathrm{H}$ & 0.39380662710280 & 3.98015153816045 & 19.90598863625216 \\
\hline $\mathrm{C}$ & -0.02333881976046 & 5.92945252207516 & 20.68254783564756 \\
\hline $\mathrm{H}$ & 0.84880647814833 & 5.93715599871402 & 21.32415279358221 \\
\hline $\mathrm{C}$ & -0.87397692133347 & 7.03644169847765 & 20.65733654512257 \\
\hline $\mathrm{H}$ & -0.66783116438754 & 7.90170260047684 & 21.27577427825372 \\
\hline $\mathrm{C}$ & -1.96708225537962 & 7.01407009387772 & 19.82085283519962 \\
\hline $\mathrm{C}$ & -3.01777060411592 & 8.07874754411631 & 19.58246869012959 \\
\hline $\mathrm{H}$ & -2.79954625101698 & 9.06614332908988 & 19.97682976649644 \\
\hline $\mathrm{C}$ & -4.35374543115931 & 7.48738378960089 & 19.99093980940915 \\
\hline $\mathrm{C}$ & -5.24987813934495 & 7.91523529238600 & 20.95089821087262 \\
\hline $\mathrm{H}$ & -5.04141229164172 & 8.79389518300924 & 21.54922663565163 \\
\hline $\mathrm{C}$ & -6.42510973555396 & 7.19424198372557 & 21.13732725918838 \\
\hline $\mathrm{H}$ & -7.13716689020392 & 7.51426591807297 & 21.88755645669069 \\
\hline $\mathrm{C}$ & -6.69558002746617 & 6.07053187013179 & 20.36976170657164 \\
\hline $\mathrm{H}$ & -7.61627744031686 & 5.52288319202017 & 20.52703936107405 \\
\hline $\mathrm{C}$ & -5.79558635715660 & 5.64172779286331 & 19.39936824640316 \\
\hline $\mathrm{H}$ & -6.00911718060280 & 4.76671401402908 & 18.79778170411694 \\
\hline $\mathrm{C}$ & -4.62811878151098 & 6.35514005257057 & 19.21604652021729 \\
\hline $\mathrm{C}$ & 0.30575423398329 & 8.67828159294505 & 16.62236243128498 \\
\hline $\mathrm{C}$ & 1.38376578670437 & 9.15195243229730 & 17.38245841146887 \\
\hline
\end{tabular}




\begin{tabular}{llll}
$\mathrm{C}$ & 2.65082517653496 & 9.15889460123912 & 16.81712037744535 \\
$\mathrm{H}$ & 3.48948125257009 & 9.50242100914202 & 17.41285440374455 \\
$\mathrm{C}$ & 2.86508510562852 & 8.74290475501401 & 15.51132228624988 \\
$\mathrm{C}$ & 1.76929439691116 & 8.32618851334719 & 14.76551872206169 \\
$\mathrm{H}$ & 1.91928734992596 & 8.02350504249387 & 13.73428760852078 \\
$\mathrm{C}$ & 0.48350637640265 & 8.27641091155395 & 15.28589042121517 \\
$\mathrm{C}$ & 1.19034052561756 & 9.61460659111670 & 18.80051540967411 \\
$\mathrm{H}$ & 0.39115946944546 & 10.35177732899050 & 18.86909882730034 \\
$\mathrm{H}$ & 2.11055862829322 & 10.05357543230316 & 19.18452719445367 \\
$\mathrm{H}$ & 0.90672526842797 & 8.78292807067770 & 19.44638946028395 \\
$\mathrm{C}$ & 4.23777388585014 & 8.76748150973251 & 14.89853904728350 \\
$\mathrm{H}$ & 4.32172255517735 & 9.57572351606405 & 14.16907091175999 \\
$\mathrm{H}$ & 4.45184685934579 & 7.83390632011828 & 14.37647657646488 \\
$\mathrm{H}$ & 5.00806310275426 & 8.91837882531991 & 15.65386978155182 \\
$\mathrm{H}$ & -0.62998916063480 & 7.82947094276751 & 14.37780754629289 \\
$\mathrm{H}$ & -0.28514735228746 & 7.84321507865532 & 13.34392488305699 \\
$\mathrm{H}$ & -1.50515931288330 & 8.47309578771606 & 14.46082271718496 \\
& -0.96391433376512 & 6.82210371653217 & 14.62179197013595 \\
\hline
\end{tabular}

\section{S.3.3.2 Coordinates (xyz) of Cyclooctyne}

$\begin{array}{llll}\text { C } & -5.05136060237971 & 7.76633963664378 & 12.77113456674935 \\ \text { C } & -5.61786794182998 & 6.81929929989917 & 13.24024646254671 \\ \text { C } & -4.39222888579630 & 9.06951356113402 & 12.82791480045577 \\ \text { C } & -6.32852765180634 & 6.12317260084363 & 14.31082670355978 \\ \text { C } & -4.12159376720124 & 9.33670255724211 & 14.32262523792014 \\ \text { H } & -5.03332696600243 & 9.84574864183508 & 12.39952808438225 \\ \text { H } & -3.45435071781816 & 9.08229196759971 & 12.26853535698378\end{array}$




$\begin{array}{llcl}\mathrm{C} & -5.34527064273602 & 9.53483102146532 & 15.23376669329582 \\ \mathrm{H} & -3.50574536038599 & 10.23712483437032 & 14.41558060814350 \\ \mathrm{H} & -3.51230139531971 & 8.50882899904267 & 14.69561004684128 \\ \mathrm{C} & -6.15668646583501 & 7.01741038362024 & 15.56362367386473 \\ \mathrm{H} & -5.93628385007921 & 5.12048928212297 & 14.49118637716207 \\ \mathrm{H} & -7.38780148553768 & 6.01377586208924 & 14.06228267027820 \\ \mathrm{C} & -6.49499579685637 & 8.50322106419716 & 15.30769508259225 \\ \mathrm{H} & -5.80867779521013 & 10.49312370627265 & 14.97371161569592 \\ \mathrm{H} & -4.94835149006823 & 9.67079081708155 & 16.24576674098974 \\ \mathrm{H} & -5.12504500728689 & 6.92011625916507 & 15.91397058104064 \\ \mathrm{H} & -6.79236766293409 & 6.62239272877823 & 16.36045030442831 \\ \mathrm{H} & -7.09839350677224 & 8.57490733945301 & 14.39976985994972 \\ \mathrm{H} & -7.14433300814428 & 8.85238943714405 & 16.11560453312003\end{array}$

\section{S.3.3.3 Coordinates (xyz) of TS1}

$\begin{array}{lrrr}\mathrm{P} & -3.14176386654099 & 7.65306661631833 & 17.27991888856165 \\ \mathrm{~N} & -1.62184532796320 & 7.51364666104160 & 16.53906594487603 \\ \mathrm{~N} & -0.81800234936795 & 8.44929674811317 & 16.57131494200589 \\ \mathrm{C} & -3.10076444952918 & 5.83569664848089 & 17.96587041595419 \\ \mathrm{H} & -3.07348854719210 & 5.03839989115697 & 17.22788072870249 \\ \mathrm{C} & -1.92905437713991 & 5.91107627144793 & 18.90662510279898 \\ \mathrm{C} & -0.90134495980011 & 5.01140504182379 & 19.10740425929322 \\ \mathrm{H} & -0.86909221368338 & 4.07790288817087 & 18.55726213156152 \\ \mathrm{C} & 0.09832416094406 & 5.32252417554589 & 20.02841565207695 \\ \mathrm{H} & 0.91057463931643 & 4.62422696311480 & 20.19299466209585 \\ \mathrm{C} & 0.06360806128647 & 6.51540970372997 & 20.73317789159334 \\ \mathrm{H} & 0.84732595306731 & 6.74503673190923 & 21.44537824007450\end{array}$




\begin{tabular}{|c|c|c|c|}
\hline $\mathrm{C}$ & -0.96745662611612 & 7.42986885168751 & 20.52125971696293 \\
\hline $\mathrm{H}$ & -0.98901591399014 & 8.36986412483238 & 21.06159578531635 \\
\hline $\mathrm{C}$ & -1.95159902261782 & 7.12417392402046 & 19.60542956254063 \\
\hline $\mathrm{C}$ & -3.13871003809759 & 7.94678517892931 & 19.17517380943404 \\
\hline $\mathrm{H}$ & -3.14168745767086 & 8.97867117213407 & 19.51596899834130 \\
\hline C & -4.38234234998785 & 7.15214188770731 & 19.48012022561086 \\
\hline C & -5.45504983388275 & 7.48665233135709 & 20.28543473760373 \\
\hline $\mathrm{H}$ & -5.47203679790385 & 8.43184658719794 & 20.81714895658737 \\
\hline $\mathrm{C}$ & -6.50999960371573 & 6.58878749868969 & 20.40414474985647 \\
\hline $\mathrm{H}$ & -7.35580428568475 & 6.83445274492094 & 21.03538615938300 \\
\hline $\mathrm{C}$ & -6.48771829185296 & 5.38052766914124 & 19.72015790222380 \\
\hline $\mathrm{H}$ & -7.31725061916943 & 4.69090069203148 & 19.82233911521368 \\
\hline $\mathrm{C}$ & -5.41121908461351 & 5.04674396165606 & 18.90471463154993 \\
\hline $\mathrm{H}$ & -5.39969553944084 & 4.10423492095252 & 18.36903897441956 \\
\hline $\mathrm{C}$ & -4.35744871838987 & 5.93434478201239 & 18.78982762020827 \\
\hline $\mathrm{C}$ & 0.32664804945154 & 8.34761221694784 & 15.71420495048808 \\
\hline $\mathrm{C}$ & 1.57104221764562 & 8.34687643387027 & 16.34027204795960 \\
\hline $\mathrm{C}$ & 2.70500424125170 & 8.30401293435923 & 15.53945028814489 \\
\hline $\mathrm{H}$ & 3.68057583485602 & 8.28467230366295 & 16.01485122216719 \\
\hline C & 2.62042643695420 & 8.29133799254365 & 14.15371073004540 \\
\hline $\mathrm{C}$ & 1.35930496346523 & 8.31228546767803 & 13.56858597183781 \\
\hline $\mathrm{H}$ & 1. 27673226798452 & 8.31046940332890 & 12.48583666991604 \\
\hline $\mathrm{C}$ & 0.19487013807257 & 8.33417797964862 & 14.32483998410216 \\
\hline $\mathrm{C}$ & 3.85908241715391 & 8.27918447442880 & 13.29933126381231 \\
\hline $\mathrm{C}$ & -1.15146111186801 & 8.36078305293179 & 13.65498135538556 \\
\hline$C$ & 1.66851750724347 & 8.35081074625155 & 17.83944776274298 \\
\hline $\mathrm{C}$ & -1.88003762640711 & 10.24134177193346 & 16.70292867414710 \\
\hline
\end{tabular}




\begin{tabular}{|c|c|c|c|}
\hline $\mathrm{C}$ & -3.04593739361558 & 9.90870029608234 & 16.94903707463775 \\
\hline C & -0.83555890012199 & 11.24794806795756 & 16.45633897048139 \\
\hline C & -4.39522750622092 & 10.47718549750276 & 17.18238001856513 \\
\hline $\mathrm{C}$ & -1.48043415165686 & 12.57722508463139 & 16.03718503236859 \\
\hline $\mathrm{H}$ & -0.15399214969087 & 10.91465412790232 & 15.67075280216622 \\
\hline $\mathrm{H}$ & -0.22769572731873 & 11.37717525350748 & 17.35830321265463 \\
\hline $\mathrm{C}$ & -2.19188791692331 & 13.37123904658751 & 17.13653849944044 \\
\hline $\mathrm{H}$ & -2.17139074536726 & 12.37192961305017 & 15.21434737144147 \\
\hline $\mathrm{H}$ & -0.69696382302179 & 13.21701146809518 & 15.62105846386460 \\
\hline $\mathrm{C}$ & -4.41251175579940 & 12.00876443500872 & 17.09925706537731 \\
\hline $\mathrm{H}$ & -4.74751620153429 & 10.15165531137694 & 18.16878104625376 \\
\hline $\mathrm{H}$ & -5.09977393127663 & 10.04415345372201 & 16.46794401012058 \\
\hline $\mathrm{C}$ & -3.30795040343396 & 12.68111243110036 & 17.93365011897959 \\
\hline $\mathrm{H}$ & -2.60796495631820 & 14.26866748444715 & 16.66592074287867 \\
\hline $\mathrm{H}$ & -1.44146020134664 & 13.72990724956643 & 17.84941878252490 \\
\hline $\mathrm{H}$ & -3.75137782163575 & 13.44081985762179 & 18.58231410188493 \\
\hline $\mathrm{H}$ & -2.86804457742580 & 11.94092959414213 & 18.60774894272651 \\
\hline $\mathrm{H}$ & -5.39592424502591 & 12.35806633743388 & 17.42430942833934 \\
\hline $\mathrm{H}$ & -4.32094801766081 & 12.30522028864962 & 16.05018501842953 \\
\hline $\mathrm{H}$ & 2.70775458926993 & 8.41865688900421 & 18.16069965671643 \\
\hline $\mathrm{H}$ & 1.23638726845001 & 7.44300312364210 & 18.26601785668164 \\
\hline $\mathrm{H}$ & 1.11307469732426 & 9.18719598528189 & 18.26922276764779 \\
\hline $\mathrm{H}$ & -1.04451203530583 & 8.61178106812334 & 12.59982973323650 \\
\hline $\mathrm{H}$ & -1.81761702482243 & 9.09114801340779 & 14.11876155869678 \\
\hline $\mathrm{H}$ & -1.64534363536415 & 7.39083485450770 & 13.72899056012706 \\
\hline $\mathrm{H}$ & 3.79151494167205 & 7.52275237990041 & 12.51513772980317 \\
\hline & 4.74847724428745 & 8.07071917474700 & 13.89419191417712 \\
\hline
\end{tabular}




\section{S.3.3.4 Coordinates (xyz) of I1}

\begin{tabular}{|c|c|c|c|}
\hline $\mathrm{P}$ & -1.79707914217706 & 7.62799352631592 & 18.45286865268877 \\
\hline $\mathrm{N}$ & -0.30317160936968 & 7.58040936959691 & 17.87620802263179 \\
\hline $\mathrm{N}$ & -0.07942979884578 & 8.80509448653734 & 17.26257867980353 \\
\hline C & -2.97647245118792 & 6.17455389656693 & 18.07141562525102 \\
\hline $\mathrm{H}$ & -3.21373336577594 & 5.99992651013495 & 17.02545502724672 \\
\hline $\mathrm{C}$ & -2.20935005720670 & 5.09328249224550 & 18.77694828156427 \\
\hline J & -1.91108773402382 & 3.81365490844664 & 18.34352284163681 \\
\hline $\mathrm{H}$ & -2.27045127282139 & 3.45731324912210 & 17.38500886506433 \\
\hline C & -1.14004558763841 & 2.99202394726383 & 19.15526612397883 \\
\hline $\mathrm{H}$ & -0.90561500124529 & 1.98519728153553 & 18.83080304549593 \\
\hline C & -0.66122448920814 & 3.45112920645112 & 20.37611795932101 \\
\hline & -0.05696832512775 & 2.79946947290421 & 20.99590202497958 \\
\hline & -0.94170492635316 & 4.74212761213655 & 20.80437051287861 \\
\hline $\mathrm{H}$ & -0.55432299937806 & 5.10556036840641 & 21.74931062063069 \\
\hline X & -1.72118057742088 & 5.55727674350512 & 20.00330262464847 \\
\hline & -2.11706010121342 & 6.99023325874890 & 20.22127150726322 \\
\hline & -1.61654974051526 & 7.51437437970357 & 21.03089866452396 \\
\hline 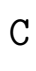 & -3.61335188984994 & 7.09961443944380 & 20.17621829075446 \\
\hline & -4.47203727545201 & 7.66020111148336 & 21.10822119967557 \\
\hline & -4.09236153910405 & 8.02707771860488 & 22.05497594645814 \\
\hline C & -5.82334784376827 & 7.75587844462946 & 20.80586438924860 \\
\hline 1 & -6.50657071850706 & 8.18802985283176 & 21.52722011470456 \\
\hline ; & -6.30792137445040 & 7.30790237825309 & 19.58115747655939 \\
\hline & -7.36449223813617 & 7.39568051779789 & 19.35790920230839 \\
\hline
\end{tabular}




\begin{tabular}{|c|c|c|c|}
\hline $\mathrm{C}$ & -5.45004353113576 & 6.75270496344407 & 18.64173861955189 \\
\hline $\mathrm{H}$ & -5.82765962391740 & 6.41557557781866 & 17.68311688992358 \\
\hline C & -4.10277541068477 & 6.63939038603700 & 18.94568040532260 \\
\hline C & 1.19524748332311 & 8.98700701090317 & 16.65158552104163 \\
\hline C & 2.18100829058404 & 9.69928723712750 & 17.33460633453274 \\
\hline $\mathrm{C}$ & 3.42245230602403 & 9.84484736780030 & 16.73202118326611 \\
\hline $\mathrm{H}$ & 4.20013493636533 & 10.39268899628114 & 17.25580245672203 \\
\hline $\mathrm{C}$ & 3. 69892937207216 & 9.28894120927432 & 15.48724509117600 \\
\hline $\mathrm{C}$ & 2.69755695665490 & 8.57505825776444 & 14.84424803122819 \\
\hline $\mathrm{H}$ & 2.90087287002551 & 8.12487496936596 & 13.87771718393403 \\
\hline $\mathrm{C}$ & 1.43921786358853 & 8.40696261941277 & 15.41013966743255 \\
\hline $\mathrm{C}$ & 5.06089162791293 & 9.44187629653089 & 14.86714010520966 \\
\hline $\mathrm{C}$ & 0.37389728013512 & 7.60731329248993 & 14.71790959541542 \\
\hline $\mathrm{C}$ & 1.90029208572721 & 10.28048061927734 & 18.69162557633529 \\
\hline $\mathrm{C}$ & -1.08126215228143 & 9.69260422503455 & 17.31317792757862 \\
\hline $\mathrm{C}$ & -2.21000865811036 & 9.24183587126958 & 17.98686408305737 \\
\hline $\mathrm{C}$ & -0.99342534200289 & 10.99007365748656 & 16.57193595114990 \\
\hline $\mathrm{C}$ & -3.46434608452444 & 10.03204348033931 & 18.25841413569101 \\
\hline $\mathrm{C}$ & -1.81620896349565 & 10.92504520577445 & 15.26341969051410 \\
\hline $\mathrm{H}$ & 0.04926304130665 & 11.21699320890982 & 16.35148548728962 \\
\hline $\mathrm{H}$ & -1.36151108213612 & 11.79159716804624 & 17.21657965167439 \\
\hline $\mathrm{C}$ & -3.03452357997532 & 11.84648198376154 & 15.21157855490129 \\
\hline $\mathrm{H}$ & -2.14594393010607 & 9.89380062330751 & 15.11703238250244 \\
\hline $\mathrm{H}$ & -1.16818447208586 & 11.15393872124402 & 14.41426805176045 \\
\hline $\mathrm{C}$ & -4.31831493544487 & 10.48637604081621 & 17.05514313029 \\
\hline $\mathrm{H}$ & -3.21808276103722 & 10.92175515771675 & 18.85087278 \\
\hline & -4.10258231107854 & 9.43015433496402 & 18.9060926587 \\
\hline
\end{tabular}




$\begin{array}{cccc}\mathrm{C} & -3.93875277645070 & 11.84780257780553 & 16.44774078330689 \\ \mathrm{H} & -3.62679949281206 & 11.56620476185094 & 14.33481560827607 \\ \mathrm{H} & -2.70580368184911 & 12.87552077081700 & 15.03213559910554 \\ \mathrm{H} & -4.85323182689810 & 12.37973900364442 & 16.17232780709433 \\ \mathrm{H} & -3.48284344838519 & 12.45808744600813 & 17.23455162743339 \\ \mathrm{H} & -5.34873139324861 & 10.55981243384253 & 17.41212107340922 \\ \mathrm{H} & -4.32292172615168 & 9.70379027922429 & 16.28986731368754 \\ \mathrm{H} & 0.72827693845021 & 7.23869954572485 & 13.75554448390726 \\ \mathrm{H} & -0.52105834134127 & 8.20972699407263 & 14.54618217941001 \\ \mathrm{H} & 0.07596108702587 & 6.75970486417202 & 15.33751230896988 \\ \mathrm{H} & 2.81894991893025 & 10.63628620667931 & 19.15763992773946 \\ \mathrm{H} & 1.44164851173578 & 9.53340920182264 & 19.34178746274581 \\ \mathrm{H} & 1.20806559067240 & 11.12407674467470 & 18.62944632711442 \\ \mathrm{H} & 5.09699512488656 & 8.98729297423655 & 13.87706327009220 \\ \mathrm{H} & 5.82489609883137 & 8.96350743993992 & 15.48445421238648 \\ \mathrm{H} & 5.33402819967803 & 10.49431510062068 & 14.76589316029958\end{array}$

\section{S.3.3.5 Coordinates (xyz) of TS2}

$\begin{array}{llll}\mathrm{P} & -1.89810553974001 & 7.96553271324456 & 18.51244151874142 \\ \mathrm{~N} & -0.36987532237299 & 7.98131160319786 & 17.98252282204552 \\ \mathrm{~N} & -0.13050147019892 & 9.16509300248099 & 17.37449137391053 \\ \mathrm{C} & -3.79056180141551 & 6.36750100612531 & 18.45317878379030 \\ \mathrm{H} & -4.34381272596319 & 6.29939630784408 & 17.52053083872382 \\ \mathrm{C} & -2.89373409674013 & 5.29801706047483 & 18.78782906879292 \\ \mathrm{C} & -2.73112230830064 & 4.12330901370495 & 18.03644532135080 \\ \mathrm{H} & -3.37116059852036 & 3.94597702568205 & 17.17924148645479 \\ \mathrm{C} & -1.77704512697117 & 3.20369588104534 & 18.39611492426746\end{array}$




\begin{tabular}{|c|c|c|c|}
\hline $\mathrm{H}$ & -1.66679053770715 & 2.28898758391661 & 17.82560959049785 \\
\hline $\mathrm{C}$ & -0.93560136287607 & 3.44226426661619 & 19.49325018873110 \\
\hline $\mathrm{H}$ & -0.18168110619590 & 2.71153455731878 & 19.75995730595842 \\
\hline $\mathrm{C}$ & -1.05519062619544 & 4.60273820207423 & 20.21863838898558 \\
\hline $\mathrm{H}$ & -0.38969991329964 & 4.80150219685137 & 21.05132344098415 \\
\hline $\mathrm{C}$ & -2.04591098300465 & 5.53756915955233 & 19.88564192090752 \\
\hline $\mathrm{C}$ & -2.19406032309637 & 6.84150112159431 & 20.48982172549201 \\
\hline $\mathrm{H}$ & -1.45720320671228 & 7.14259880792547 & 21.22942925452189 \\
\hline $\mathrm{C}$ & -3.53977773351366 & 7.34005279107672 & 20.63995772461425 \\
\hline $\mathrm{C}$ & -3.98783592958592 & 8.14891989086863 & 21.69582927114380 \\
\hline $\mathrm{H}$ & -3.32858164066025 & 8.34373600062217 & 22.53466636058788 \\
\hline $\mathrm{C}$ & -5.25559380467371 & 8.67649555403324 & 21.66874101080323 \\
\hline $\mathrm{H}$ & -5.60935061926175 & 9.28151424352995 & 22.49486687188089 \\
\hline $\mathrm{C}$ & -6.09751157412487 & 8.43953432131989 & 20.56856642122481 \\
\hline $\mathrm{H}$ & -7.09431828692690 & 8.86432701989780 & 20.55651993919550 \\
\hline $\mathrm{C}$ & -5.66509431285502 & 7.67969440451620 & 19.51117461256472 \\
\hline $\mathrm{H}$ & -6.31084341698597 & 7.50904048783074 & 18.65685902813238 \\
\hline $\mathrm{C}$ & -4.38064477593421 & 7.10319939865442 & 19.53333032636253 \\
\hline $\mathrm{C}$ & 1.17081670951178 & 9.38791508526432 & 16.82289834754737 \\
\hline $\mathrm{C}$ & 2.07387809547128 & 10.17859116567320 & 17.52785080783490 \\
\hline $\mathrm{C}$ & 3.33316942215925 & 10.38511486953585 & 16.97538468155242 \\
\hline $\mathrm{H}$ & 4.04907453482915 & 10.99530637989628 & 17.51670469455865 \\
\hline $\mathrm{C}$ & 3.70111195703838 & 9.81612276874271 & 15.76454889845030 \\
\hline $\mathrm{C}$ & 2.77818417252224 & 9.01363942650860 & 15.10192404985151 \\
\hline $\mathrm{H}$ & 3.05587323017716 & 8.54699361510356 & 14.16173055107737 \\
\hline $\mathrm{C}$ & 1.51039842071036 & 8.77891342723317 & 15.61469828747886 \\
\hline $\mathrm{C}$ & 5.07348274694602 & 10.03517141216211 & 15.18868857839384 \\
\hline
\end{tabular}




\begin{tabular}{|c|c|c|c|}
\hline $\mathrm{C}$ & 0.55401494019558 & 7.85826737469560 & 14.91229410764763 \\
\hline $\mathrm{C}$ & 1.70925932569617 & 10.77210789150475 & 18.85999066936108 \\
\hline C & -1.13917254884445 & 10.06260489368399 & 17.39189997288856 \\
\hline C & -2.26421819100163 & 9.59275641632883 & 18.04135059643453 \\
\hline C & -1.07106699361164 & 11.34361817565081 & 16.62395008851563 \\
\hline $\mathrm{C}$ & -3.56853742057739 & 10.33111516619013 & 18.14642724334309 \\
\hline $\mathrm{C}$ & -1.50082650670597 & 11.16006028750585 & 15.15972763982356 \\
\hline $\mathrm{H}$ & -0.06338539340567 & 11.76223773837659 & 16.64835630972654 \\
\hline $\mathrm{H}$ & -1.72643994926745 & 12.06610106689339 & 17.11391058877486 \\
\hline $\mathrm{C}$ & -2.78429142235805 & 10.35646915310192 & 14.94019038056365 \\
\hline $\mathrm{H}$ & -0.68573158095192 & 10.67398138050913 & 14.61485198370303 \\
\hline $\mathrm{H}$ & -1.61572240705852 & 12.15343256579338 & 14.71486600459356 \\
\hline $\mathrm{C}$ & -4.48047304643674 & 10.17309694780001 & 16.92501147147525 \\
\hline $\mathrm{H}$ & -3.37952136891232 & 11.39612744086747 & 18.32134981796048 \\
\hline $\mathrm{H}$ & -4.11030685010363 & 9.97999088519139 & 19.02712838653732 \\
\hline $\mathrm{C}$ & -4.04613890169890 & 10.89125934341482 & 15.64285517865240 \\
\hline $\mathrm{H}$ & -2.62141548219516 & 9.31526691992563 & 15.23567976498612 \\
\hline $\mathrm{H}$ & -2.96202388173434 & 10.33180734034590 & 13.86199866432874 \\
\hline $\mathrm{H}$ & -4.88297942099723 & 10.82143252444899 & 14.94322040606302 \\
\hline $\mathrm{H}$ & -3.92754695804107 & 11.96184148658350 & 15.85048263175920 \\
\hline $\mathrm{H}$ & -5.47519145393443 & 10.53957888522678 & 17.19748021803938 \\
\hline $\mathrm{H}$ & -4.59676202917556 & 9.10407043499447 & 16.71394092787150 \\
\hline $\mathrm{H}$ & 2.59315834299889 & 11.17262732750769 & 19.35563825408979 \\
\hline $\mathrm{H}$ & 1.25510569945633 & 10.02045913432067 & 19.50789859205510 \\
\hline $\mathrm{H}$ & 0.98780970105689 & 11.58612869880654 & 18.75531058736138 \\
\hline $\mathrm{H}$ & 5.67083382504738 & 10.69023514963473 & 15.82288161954384 \\
\hline $\mathrm{H}$ & 5.01642216311571 & 10.48674389308544 & 14.19594686362395 \\
\hline
\end{tabular}




$\begin{array}{cccc}\text { H } & 5.60799139068864 & 9.08830493348778 & 15.08710130148559 \\ \text { H } & 0.89347702944626 & 7.65207267622148 & 13.89751790002754 \\ \text { H } & -0.45175531504363 & 8.27859969138656 & 14.86279278299884 \\ \text { H } & 0.47349455882087 & 6.91444240439690 & 15.45483062835358\end{array}$

\section{S.3.3.6 Coordinates (xyz) of Compound 2}

$\begin{array}{lccc}\mathrm{P} & -2.10012241360236 & 7.89629948334026 & 18.52290191271638 \\ \mathrm{~N} & -0.64181061359437 & 7.74484394388421 & 17.79738635331442 \\ \mathrm{~N} & -0.31010280462169 & 8.87985595186235 & 17.19062459943123 \\ \mathrm{C} & 0.95808262524533 & 8.92127986422461 & 16.51603295643453 \\ \mathrm{C} & 2.06193646472465 & 9.43668330077728 & 17.19236603292985 \\ \mathrm{C} & 3.28359095195772 & 9.44190943390651 & 16.53481218549044 \\ \mathrm{H} & 4.15392892818430 & 9.83877223832143 & 17.04837536337310 \\ \mathrm{C} & 3.42207661946360 & 8.93826277751014 & 15.24569837824750 \\ \mathrm{C} & 2.29988204042631 & 8.42311461088973 & 14.61250229496795 \\ \mathrm{H} & 2.39379890019016 & 8.01660811832710 & 13.61067611951024 \\ \mathrm{C} & 1.05481475532209 & 8.40025314002794 & 15.23086253235969 \\ \mathrm{C} & 4.76740668370913 & 8.92508942668558 & 14.57341959361328 \\ \mathrm{C} & -0.14134605808581 & 7.80216488383486 & 14.54793859423784 \\ \mathrm{C} & 1.93144023408648 & 9.95598111633431 & 18.59625655802461 \\ \mathrm{C} & -1.19307951259611 & 9.90893040075103 & 17.28182605263074 \\ \mathrm{C} & -2.30522806430994 & 9.54984360625200 & 18.01646311592033 \\ \mathrm{C} & -0.95640141713384 & 11.19684318111339 & 16.55577018864576 \\ \mathrm{C} & -3.48317986232114 & 10.42104524906664 & 18.35997650375458 \\ \mathrm{H} & -1.84773800904365 & 11.31078732811128 & 15.29683746811871 \\ \mathrm{H} & 0.09600313513390 & 11.27071720774708 & 16.28134096344066 \\ \mathrm{H} & -1.15627709692743 & 12.02621180739395 & 17.23893675185301\end{array}$




\begin{tabular}{|c|c|c|c|}
\hline $\mathrm{C}$ & -2.96557601826974 & 12.35268306222618 & 15.37551959315205 \\
\hline $\mathrm{H}$ & -2.28858399888619 & 10.33075980318176 & 15.09841049494993 \\
\hline $\mathrm{H}$ & -1.22511614740414 & 11.53789584927165 & 14.42832361320167 \\
\hline $\mathrm{C}$ & -4.29548962337448 & 11.02373070166186 & 17.19648630976307 \\
\hline $\mathrm{H}$ & -3.15654519799146 & 11.23998459605486 & 19.01116740308056 \\
\hline $\mathrm{H}$ & -4.16028768188584 & 9.81932732942056 & 18.97194672361239 \\
\hline $\mathrm{C}$ & -3.78593576953224 & 12.37569324212953 & 16.66805608639650 \\
\hline $\mathrm{H}$ & -3.63800515074779 & 12.18323984901739 & 14.52850848721290 \\
\hline $\mathrm{H}$ & -2.54244002685615 & 13.35129077289975 & 15.22551038997949 \\
\hline $\mathrm{H}$ & -4.64041449843675 & 13.03418749948213 & 16.49245666139597 \\
\hline $\mathrm{H}$ & -3.21118897977997 & 12.86592419497018 & 17.46017517482342 \\
\hline $\mathrm{H}$ & -5.31426998748127 & 11.16835139930521 & 17.56291155534157 \\
\hline $\mathrm{H}$ & -4.37299854983109 & 10.29370411556142 & 16.38511301418892 \\
\hline $\mathrm{H}$ & 0.12012570013023 & 7.45276744449969 & 13.54967151446588 \\
\hline $\mathrm{H}$ & -0.95093824581227 & 8.52856734519779 & 14.45366520988636 \\
\hline $\mathrm{H}$ & -0.52961809092843 & 6.96032874665847 & 15.12395554067528 \\
\hline $\mathrm{H}$ & 4.68766452056201 & 8.61257780308036 & 13.53209695620174 \\
\hline $\mathrm{H}$ & 5.44524576110332 & 8.23349727921571 & 15.07932273007632 \\
\hline $\mathrm{H}$ & 5.23135891401084 & 9.91288536002571 & 14.59764791896545 \\
\hline $\mathrm{H}$ & 1.40981178899452 & 9.23655100571454 & 19.22919998625203 \\
\hline $\mathrm{H}$ & 1.35997833508990 & 10.88724414408161 & 18.62608419550913 \\
\hline $\mathrm{H}$ & 2.91325746111966 & 10.14779138598197 & 19.02728592185447 \\
\hline
\end{tabular}

\section{S.3.3.7 Coordinates (xyz) of Anthracene}

$\begin{array}{lrrr}\text { C } & -3.70152477824227 & 5.31473469420820 & 19.01734806719419 \\ \text { C } & -2.35692618656444 & 5.61603674641048 & 19.21002200154595 \\ \text { C } & -1.31151479085600 & 4.84578146780278 & 18.61391878791035\end{array}$




\begin{tabular}{|c|c|c|c|}
\hline $\mathrm{H}$ & -1.58322615257112 & 3.99980983643906 & 17.99218728812873 \\
\hline $\mathrm{C}$ & -0.00927307782577 & 5.16219140227474 & 18.81772739537071 \\
\hline $\mathrm{H}$ & 0.77296358768658 & 4.57062128059513 & 18.35721253854617 \\
\hline $\mathrm{C}$ & 0.34357498949792 & 6.27327998957628 & 19.63653729409900 \\
\hline $\mathrm{H}$ & 1.38960621519663 & 6.50920879783488 & 19.79148056697354 \\
\hline $\mathrm{C}$ & -0.61877992212488 & 7.03011959244238 & 20.21849185410770 \\
\hline $\mathrm{H}$ & -0.35273030144610 & 7.87646334349399 & 20.84220530725623 \\
\hline $\mathrm{C}$ & -2.00315532371308 & 6.73292718035703 & 20.02747241198045 \\
\hline $\mathrm{C}$ & -3.01167855011250 & 7.49269750495858 & 20.61204679865903 \\
\hline $\mathrm{C}$ & -4.35627177250757 & 7.19139988559214 & 20.41936078210115 \\
\hline C & -5.40167834844170 & 7.96165976071636 & 21.01545658769465 \\
\hline C & -6.70391742055924 & 7.64525141110161 & 20.81166113331108 \\
\hline $\mathrm{C}$ & -7.05677459106568 & 6.53416332324394 & 19.99284877005972 \\
\hline $\mathrm{C}$ & -6.09441836173403 & 5.77732672782928 & 19.41088691045747 \\
\hline C & -4.71004502457515 & 6.07450622271791 & 19.60191543502989 \\
\hline $\mathrm{H}$ & -5.12996929488466 & 8.80763847045932 & 21.63718067520188 \\
\hline $\mathrm{H}$ & -7.48615022232557 & 8.23682837711006 & 21.27217289581532 \\
\hline $\mathrm{H}$ & -6.36046989164580 & 4.93098639697150 & 18.78716945999065 \\
\hline $\mathrm{H}$ & -8.10280497264714 & 6.29824112567935 & 19.83790415874263 \\
\hline $\mathrm{H}$ & -2.74274605470080 & 8.34063153576907 & 21.23419566622252 \\
\hline $\mathrm{H}$ & -3.97045975383761 & 4.46679492641592 & 18.39 \\
\hline
\end{tabular}




\section{S.3.4 Natural Bond Orbital (NBO) Analysis of Unsubstituted 3}

Natural bond orbital (NBO) calculations were performed using $\mathrm{NBO}^{21}$ within the ORCA program. The geometry of unsubstituted 3 was optimized using keywords $\omega$ B97X-D3 MA-def2-TZVPP def2/J TightSCF RIJCOSX Grid5 FinalGrid6 Opt and the optimized coordinates are listed in section S.3.4.1. The natural resonance theory (NRT) ${ }^{22-24}$ keyword was specified to generate natural resonance structures of the parent molecule. The lower contributing resonance structures (all below 2.5\%) are not discussed.

Analysis of the parent heterocycle by natural resonance theory (NRT) revealed natural bond orders of 1.19 and 1.50 for the carbon-phosphorus and the carbon-oxygen bonds, respectively (Fig. S.44B). These data are consistent with the relatively shielded ${ }^{31} \mathrm{P}\left\{{ }^{1} \mathrm{H}\right\} \mathrm{NMR}$ signal observed for P1 in 3 (Fig. S.44A). Dominant natural Lewis structures of the parent molecule were also determined (Fig. S.44C) and highlight delocalization of the $\pi$-system.
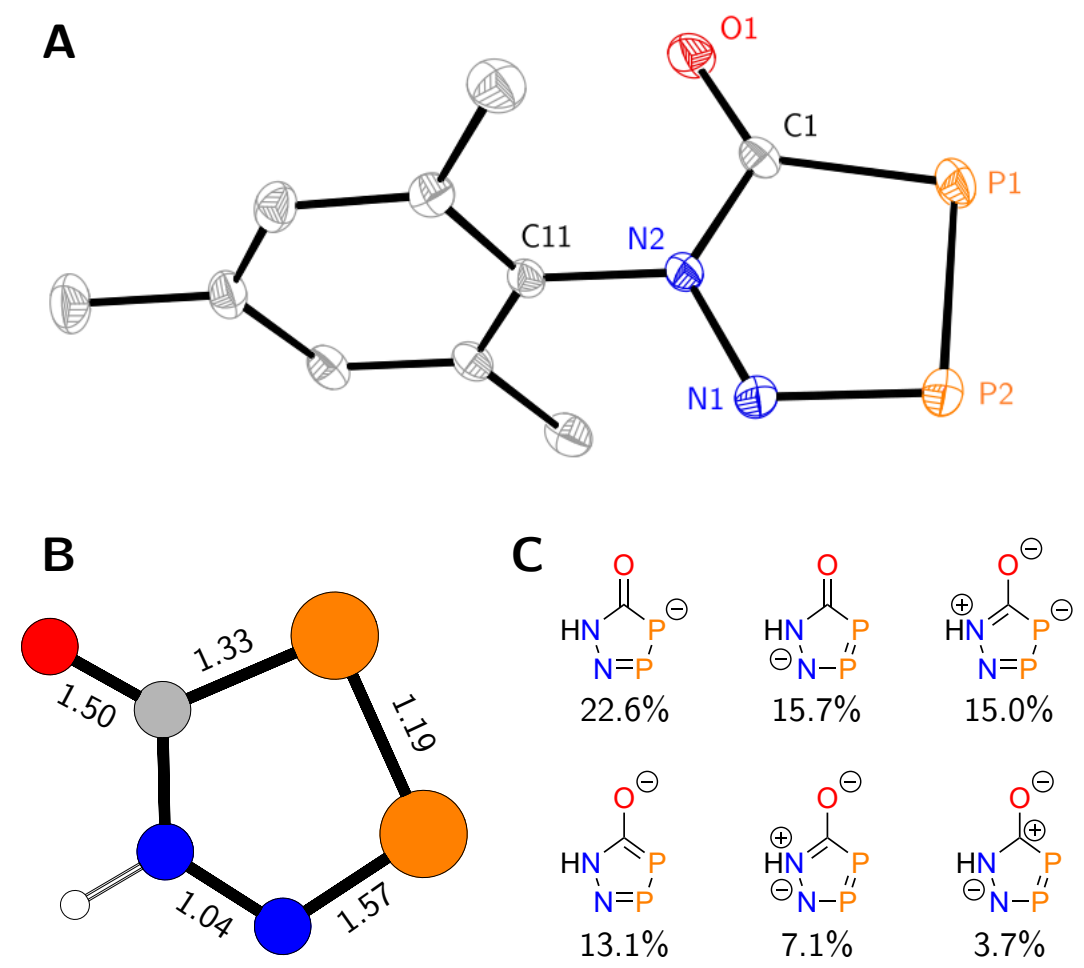

Figure S.44: A) Molecular structure of $[3]\left[\mathrm{Na}(12 \text {-crown-4 })_{2}\right]$. Thermal ellipsoids are shown at the $50 \%$ probability level and hydrogen atoms and the $\left[\mathrm{Na}(12 \text {-crown- } 4)_{2}\right]$ cation are omitted for clarity. B) Natural resonance theory (NRT) derived bond orders for the parent heterocycle. C) Resonance weights calculated for the parent molecule using NRT. 


\section{S.3.4.1 Coordinates (xyz) of Parent Molecule}

$\begin{array}{llll}\mathrm{N} & -0.82655987418337 & 1.30307921751118 & -1.18556794117264 \\ \mathrm{P} & -0.77214319777305 & -0.31730986910293 & -1.21870483028329 \\ \mathrm{~N} & -0.24018190646900 & 1.85331142875671 & -0.11115307114496 \\ \mathrm{P} & 0.27127428929077 & -0.64921084180834 & 0.56893854316906 \\ \mathrm{C} & 0.34432432999694 & 1.12516038406880 & 0.89285060619681 \\ \mathrm{O} & 0.84569841222964 & 1.69720366447507 & 1.88256022963436 \\ \mathrm{H} & -0.26873205309192 & 2.85925601609952 & -0.03593353639935\end{array}$

\section{References}

(1) Pangborn, A. B.; Giardello, M. A.; Grubbs, R. H.; Rosen, R. K.; Timmers, F. J. Safe and Convenient Procedure for Solvent Purification. Organometallics 1996, 15, 15181520.

(2) Williams, D. B. G.; Lawton, M. Drying of Organic Solvents: Quantitative Evaluation of the Efficiency of Several Desiccants. J. Org. Chem. 2010, 75, 8351-8354.

(3) Riu, M.-L. Y.; Jones, R. L.; Transue, W. J.; Müller, P.; Cummins, C. C. Isolation of an elusive phosphatetrahedrane. Sci. Adv. 2020, 6, eaaz3168.

(4) Velian, A.; Nava, M.; Temprado, M.; Zhou, Y.; Field, R. W.; Cummins, C. C. A Retro Diels-Alder Route to Diphosphorus Chemistry: Molecular Precursor Synthesis, Kinetics of $\mathrm{P}_{2}$ Transfer to 1,3-Dienes, and Detection of $\mathrm{P}_{2}$ by Molecular Beam Mass Spectrometry. J. Am. Chem. Soc. 2014, 136, 13586-13589.

(5) Filimonov, V. D.; Krasnokutskaya, E. A.; Kassanova, A. Z.; Fedorova, V. A.; Stankevich, K. S.; Naumov, N. G.; Bondarev, A. A.; Kataeva, V. A. Synthesis, Structure, and Synthetic Potential of Arenediazonium Trifluoromethanesulfonates as Stable and Safe Diazonium Salts. Eur. J. Org. Chem. 2019, 2019, 665-674. 
(6) Roberts, D. A.; Pilgrim, B. S.; Sirvinskaite, G.; Ronson, T. K.; Nitschke, J. R. Covalent Post-assembly Modification Triggers Multiple Structural Transformations of a Tetrazine-Edged $\mathrm{Fe}_{4} \mathrm{~L}_{6}$ Tetrahedron. J. Am. Chem. Soc. 2018, 140, 9616-9623.

(7) Heift, D. Sodium phosphaethynolate as a building block. Ph.D. thesis, ETH Zurich, 2013.

(8) Fulmer, G. R.; Miller, A. J. M.; Sherden, N. H.; Gottlieb, H. E.; Nudelman, A.; Stoltz, B. M.; Bercaw, J. E.; Goldberg, K. I. NMR Chemical Shifts of Trace Impurities: Common Laboratory Solvents, Organics, and Gases in Deuterated Solvents Relevant to the Organometallic Chemist. Organometallics 2010, 29, 2176-2179.

(9) Morin, M. S. T.; Lu, Y.; Black, D. A.; Arndtsen, B. A. Copper-Catalyzed Petasis-Type Reaction: A General Route to $\alpha$-Substituted Amides From Imines, Acid Chlorides, and Organoboron Reagents. J. Org. Chem 2012, 77, 2013-2017.

(10) Ammann, C.; Meier, P.; Merbach, A. A simple multinuclear NMR thermometer. J. Magn. Reson. 1982, 46, $319-321$.

(11) Sheldrick, G. M. SHELXT - Integrated space-group and crystal-structure determination. Acta Cryst. A 2015, 71, 3-8.

(12) Müller, P. Practical suggestions for better crystal structures. Crystallogr. Rev. 2009, $15,57-83$.

(13) Neese, F. The ORCA program system. WIREs Computational Molecular Science 2012, 2, 73-78.

(14) Portmann, S.; Lüthi, H. P. MOLEKEL: An Interactive Molecular Graphics Tool. Chimia 2000, 54, 766-769.

(15) Neese, F. Software update: the ORCA program system, version 4.0. WIREs Comput. Mol. Sci. 2018, 8, e1327. 
(16) Guo, Y.; Riplinger, C.; Becker, U.; Liakos, D. G.; Minenkov, Y.; Cavallo, L.; Neese, F. Communication: An improved linear scaling perturbative triples correction for the domain based local pair-natural orbital based singles and doubles coupled cluster method [DLPNO-CCSD(T)]. J. Chem. Phys. 2018, 148, 011101.

(17) Kendall, R. A.; Dunning, T. H.; Harrison, R. J. Electron affinities of the first-row atoms revisited. Systematic basis sets and wave functions. J. Chem. Phys. 1992, 96, 6796-6806.

(18) Paulechka, E; Kazakov, A. Efficient DLPNO-CCSD(T)-Based Estimation of Formation Enthalpies for C-, H-, O-, and N-Containing Closed-Shell Compounds Validated Against Critically Evaluated Experimental Data. J. Phys. Chem. A 2017, 121, 43794387.

(19) Mielczarek, D. C.; Nait Saidi, C.; Paricaud, P.; Catoire, L. Generalized Prediction of Enthalpies of Formation Using DLPNO-CCSD(T) Ab Initio Calculations for Molecules Containing the Elements H, C, N, O, F, S, Cl, Br: Generalized Prediction of Enthalpies of Formation Using DLPNO-CCSD(T) Ab Initio Calculations for Molecules Containing the Elements H, C, N, O, F, S, C. J. Comput. Chem. 2019, 40, 768-793.

(20) Hanwell, M. D.; Curtis, D. E.; Lonie, D. C.; Vandermeersch, T.; Zurek, E.; Hutchison, G. R. Avogadro: an advanced semantic chemical editor, visualization, and analysis platform. J. Cheminformatics 2012, 4, 17.

(21) Glendening, E. D.; Badenhoop, J. K.; Reed, A. E.; Carpenter, J.; Bohmann, J. A.; Morales, C. M.; Landis, C. R.; Weinhold, F. NBO6.0; Theoretical Chemistry Institute, University of Wisconsin:Madison, 2013.

(22) Glendening, E. D.; Weinhold, F. Natural resonance theory: I. General formalism. J. Comput. Chem. 1998, 19, 593-609. 
(23) Glendening, E. D.; Weinhold, F. Natural resonance theory: II. Natural bond order and valency. J. Comput. Chem. 1998, 19, 610-627.

(24) Glendening, E. D.; Badenhoop, J. K.; Weinhold, F. Natural resonance theory: III. Chemical applications. J. Comput. Chem. 1998, 19, 628-646. 